\title{
New data on the Silurian-Devonian palaeontology and biostratigraphy of Bolivia
}

\author{
Patrick R. Racheboeuf, JeAn-Georges Casier, YVes Plusquellec, MARgarita Toro, \\ David Mendoza, Maria da Gloria Pires de Carvalho, Alain le Hérissé, Florentin Paris, \\ ESPERANZA FERNÁNDEZ-MARTíNEZ, FRANCIS TOURNEUR, JEAN BROUTIN, SYLVIE CRASQUIN \& \\ PHILIPPE JANVIER
}

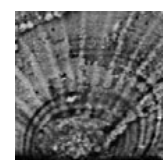

In order to precisely establish the bio- and chronostratigraphic position of several levels of the Silurian-Devonian succession of Bolivia, with respect to the International Time Scale, additional Silurian and Devonian localities belonging to the Eastern Cordillera and the Interandean Zone areas have been recently revised and sampled, both for macrofossils and palynomorphs. Specifically, the localities are Ñuñumayani, and Muruhuta from the late Silurian-early Devonian time interval. Correlations with other fossiliferous localities are discussed, namely Huacallani and Rumicorral. A new outcrop yielding Middle Devonian tabulate corals at Pisacaviña is described; its faunal content is described, and compared with the historical coral collection. As a result, it appears clearly that the Silurian-Devonian Bolivian fauna needs a thorough revision, as well as the selection of stratigraphically significant macrofossils. Besides macrofossils, the analysis of palynomorph assemblages is significant in establishment of both intra-Bolivian and international correlations before any reliable biogeographic reconstruction is done. This paper records the first discovery of a plant of the genus Protolepidodendron from the Devonian of Bolivia. An ostracod assemblage from Pisacaviña is described, illustrated, and discussed for the first time; it suggests an Early Devonian or an Eifelian age. Newly described taxa include the coral Parastriatopora boliviana sp. nov., and the chonetoidean brachiopods Sanjuanetes glemareci sp. nov., and Kentronetes giae sp. nov. $•$ Key words: Devonian, Bolivia, palaeontology, biostratigraphy, palaeobiogeography.

Racheboeuf, P.R., Casier, J.-G., Plusquellec, Y., Toro, M., Mendoza, D., Pires de Carvalho, M., Le Hérissé, A., PARis, F., Fernández-Martínez, E., Tourneur, F., Broutin, J., Crasquin, S. \& Janvier, P. 2012. New data on the Silurian-Devonian palaeontology and biostratigraphy of Bolivia. Bulletin of Geosciences 87(2), 269-314 (32 figures, 5 tables). Czech Geological Survey, Prague. ISSN 1214-1119. Manuscript received December 17, 2010; accepted in revised form September 7, 2011; published online January 4, 2012; issued March 30, 2012.

Patrick R. Racheboeuf, UMR 6538 du CNRS, Laboratoire de Paléontologie, UBO, UFR Sciences et Techniques, 6 avenue Le Gorgeu - CS 93837, 29238 Brest Cedex 3, France; patrick.racheboeuf@univ-brest.fr • Jean-Georges Casier, Department of Palaeontology, Royal Belgian Institute of Natural Sciences, Vautier street, 29, B-1000 Brussels, Belgium; casier@naturalsciences.be•Yves Plusquellec, UBO, UFR Sciences et Techniques, Laboratoire de Paléontologie, 6 avenue Le Gorgeu - CS 93837, 29238 Brest Cedex 3, France; yves.plusquellec@univ-brest.fr • Margarita Toro, Laboratorio de Paleontología IIGEMA-UMSA-Campus Universitario - Cota Cota, Casilla 4833, La Paz, Bolivia; margatoro@yahoo.com•David Mendoza,PETROBRAS Bolivia S.A., Casilla de correo 6866, Santa Cruz de la Sierra, Bolivia; david.mendoza@hotmail.com• Maria da Gloria Pires de Carvalho, Division of Paleontology, American Museum of Natural History, Central Park West at 79th street, New York, NY 10024-5129, USA; carvalho@amnh.org - Alain Le Hérissé, UMR 6538 du CNRS, Laboratoire de Paléontologie, UBO, UFR Sciences et Techniques, 6 avenue Le Gorgeu - CS 93837, 29238 Brest Cedex 3, France; alain.le.herisse@univ-brest.fr・Florentin Paris, UMR 6118 du CNRS, Géosciences-Rennes, Université de Rennes 1, 35042 Rennes Cedex, France; florentin.paris@orange.fr - Esperanza Fernández-Martínez, Área de Paleontología, Facultad de Ciencias Biológicas y Ambientales, Campus de Vegazana, s/n, Universidad de León, 24071 León, Spain; e.fernandez@unileon.es・Francis Tourneur, 21 Impasse du Blanc Bou, 5340 Faulx-les-Tombes, Belgique; francis.tourneur@pierresetmarbres.be • Jean Broutin, UMR 7207 du CNRS, Centre de Recherche sur la Paléobiodiversité et les Paléoenvironnements, Laboratoire Paléobotanique et Paléoécologie, Muséum National d'Histoire naturelle, CP 38, 57 rue Cuvier, 75231 Paris Cedex 05, France; jbroutin@snv.jussieu.fr •Sylvie Crasquin, UMR 7207 du CNRS, Centre de Recherche sur la Paléobiodiversité et les Paléoenvironnements, UPMC, Laboratoire de Micropaléontologie, T46-56, E5, case 104, 4 Place Jussieu, 75252 Paris Cedex 05, France; sylvie.crasquin@upmc.fr・Philippe Janvier, UMR 7207 du CNRS, Centre de Recherche sur la Paléobiodiversité et les Paléoenvironnements, Département Histoire de la Terre, Muséum National d'Histoire naturelle, CP 38, 57 rue Cuvier, 75231 Paris Cedex 05, France; janvier@mnhn.fr 


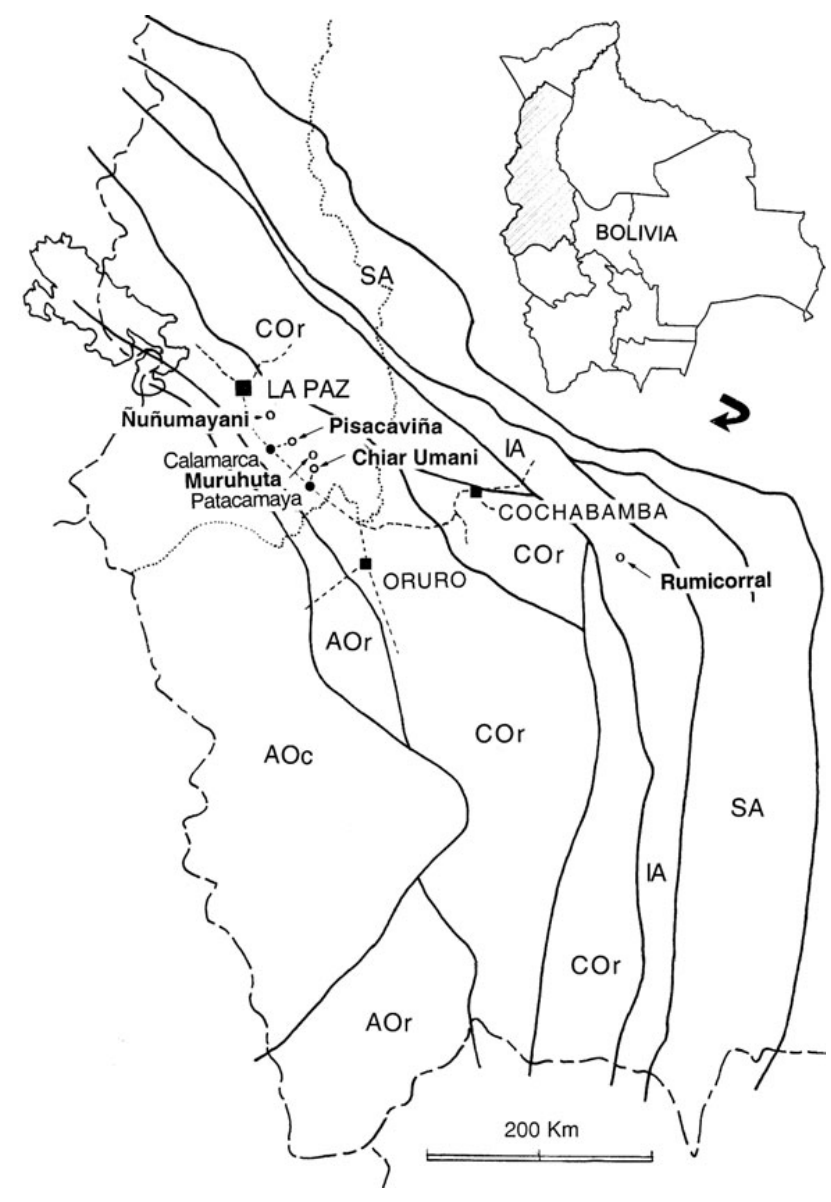

Figure 1. Schematic structural map of Bolivian Palaeozoic outcrops, with the location of the main localities cited in the text (after Semperé 1995). Abbreviation: Aoc - Western Altiplano; Aor - Eastern Altiplano; Cor - Eastern Cordillera; IA - Interandean Zone; SA - Subandean Zone.

During the last twenty years, field work on the SiluroDevonian succession of Bolivia, and especially in the Eastern Cordillera, either for sampling, mapping, or for detailed biostratigraphical studies and correlations, led to the discovery of new fossils as well as that of new Silurian and Devonian fossiliferous localities. Most of these localities are located S of La Paz, mainly between La Paz and Sica Sica, along the main road to Oruro, and belong to the Eastern Cordillera unit (Janvier 1991, 2003; Racheboeuf 1992; Racheboeuf \& Isaacson 1994; Limachi et al. 1996; Tiella et al. 1998; Toro \& García-Duarte 2002; Toro et al. 2003, 2004, 2006, 2008). Most of these studies were developed within a Bolivian-French cooperation, in continuation of several National Geographic, and IFEA (Institut Français d'Etudes Andines) grants. For the last five years, studies are part both of the 'Paleontología y bioestratigrafía de las unidades Paleozoicas' program of the IIGEMA of the UMSA, and from the Fondation de France project 'Recherches sur la Paléontologie et les Paléo-environnements des Pays Andins'.
After the recognition of fossiliferous argillaceous levels assigned to the lowermost part of the Belén Formation of Early Devonian age (Tiella et al. 1998), other fossiliferous outcrops assigned to the Silurian Uncía and Catavi formations have been recently recognized, studied, and published (Toro et al. 2003, 2004, 2006, 2008). The last field sessions on the Siluro-Devonian succession of the Eastern Cordillera resulting from Bolivian and French research workers were realized in 2005 and 2009. They have allowed us to discover a new Devonian fossiliferous locality with corals near Pisacaviña, in the lower member of the Belén Formation, as well as new fossiliferous outcrops near Muruhuta, NE of Chacoma.

This paper presents all these new results as well as their biostratigraphical and biogeographical implications. It includes the revision and/or study of known taxa, the description of an ostracod assemblage as well as that of new species, including tabulate corals and brachiopods. This paper is a contribution to the knowledge of the Silurian-Devonian succession of Bolivia, to the biostratigraphy, correlations, paleobiogeography, and climatic impact on the benthic faunas during the Silurian-Devonian time interval in South America.

Note. - Except for palynomorphs (acritarchs and chitinozoans), all the type and figured specimens are deposited in the collections of invertebrate of the Faculty of Geological Sciences, La Paz University under No. FCGI (invertebrates) or FCGV (vertebrates).

\section{Geological setting (Margarita Toro, David Mendoza, Sylvie Crasquin \& Patrick R. Racheboeuf)}

\section{The Ñuñumayani area}

Figures 1, 2

The black lutites of the Uncía Formation which crop out in the vicinity of Nuñumayani, about $20 \mathrm{~km} \mathrm{~S}$ of Apaña (SE of La Paz) yield rich fossiliferous beds. Its faunal content has been already published (Toro et al. 2003, 2006, 2008), and its biostratigraphic context discussed (Toro \& Garcia-Duarte 2002; Toro et al. 2004, 2006, 2008). Taxonomic identifications are revised herein and biostratigraphic data are discussed. The main fossiliferous locality (S $16^{\circ} 06^{\prime} 201$; W $67^{\circ} 59^{\prime} 608$, altitude $4020 \mathrm{~m}$ ) crops out sloping in an abandoned corner about $50 \mathrm{~m}$ E of the road from Apaña to Santiago de Collana, near the Ñunumayani village (Fig. 2). Fossils are irregularly distributed within the very finely laminated black shales. The first citation of the locality in the literature was by Branisa (1969, p. 35) who mentionned the 'Fauna 
de Strophochonetes' in the Kirusilla and Pampa (now Uncía) formations. Besides the chonetoidean brachiopod, the associated fauna listed in the literature includes benthic faunal elements such as the tabulate coral 'Pleurodictyum', the gastropod 'Loxonema' sp., nektobenthic elements such as the trilobites Kettneraspis aracana, and Andinacaste chojnacotensis, the tentaculitid Tentaculites sp. (Toro et al. 2003), and hyoliths. According to the occurrence of the trilobite Andinacaste chojnacotensis, a Ludlovian-Př́dolian age was assigned to the fossil-bearing beds yielding the "strophochonetid fauna' (Toro \& García-Duarte 2002, Toro et al. 2003), the trilobite species being considered to be a biostratigraphical index (Suárez-Soruco in Limachi et al. 1996).

Additional sampling of the locality and the detailed revision of faunal occurrences indicate that a chonetoidean brachiopod, which is the most common fossil, is a new representative of the genus Kentronetes. $K$. giae sp. nov. (Racheboeuf, herein), is rather suggestive of an Early Devonian age, according to its morphological characters, although it has been found associated with A. chojnacotensis in the same beds. Moreover, the $\tilde{\mathrm{Nu}}-$ numayani outcrop provided us with five specimens of the tabulate coral Petridictyum sp. (= Pleurodictyum sensu Toro \& García-Duarte 2002, Toro et al. 2004), a genus which is known to range from the Lochkovian to the Eifelian throughout the world. Two notable exceptions are: 1) the Silurian (Llandovery-Early Ludlow) North American occurrence of Pleurodictyum tennesseensis Amsden, 1949, tentatively assigned to Petridictyum (Plusquellec 2007), and 2) 'Petridictyum? sp. nov. A' Plusquellec, 2007, from the Přídolí of Victoria (Australia).

The trilobite fauna includes Kazachstania cf. $K$. gerardoi and Kettneraspis? aracana which both support a Lochkovian age (see below). The fauna undoubtedly lies below the Scaphiocoelia boliviensis assemblage which is late Lochkovian-Pragian age in Bolivia, as indicated by Racheboeuf et al. (1993a, b), and Toro et al. (2004, fig. 2). However the Scaphiocoelia fauna is typically an environmental marker (mainly bathymetric) and its age weakly varies in a N-S gradient from Bolivia to northern Argentina (Ullum area, northern Precordillera; Racheboeuf, unpublished). In the Presto-El Peral section of the Interandean Zone (E of Sucre), the Scaphiocoelia fauna is well developed in the uppermost part of the Santa Rosa Formation, in levels which have been assigned a late Lochkovian-earliest Pragian age (Racheboeuf et al. 1993a, b), while in the northern Argentine Precordillera a Pragian age appears likely (Racheboeuf, unpublished). Besides the faunal elements listed above, palynological data are suggestive of an Early Devonian age (see below).

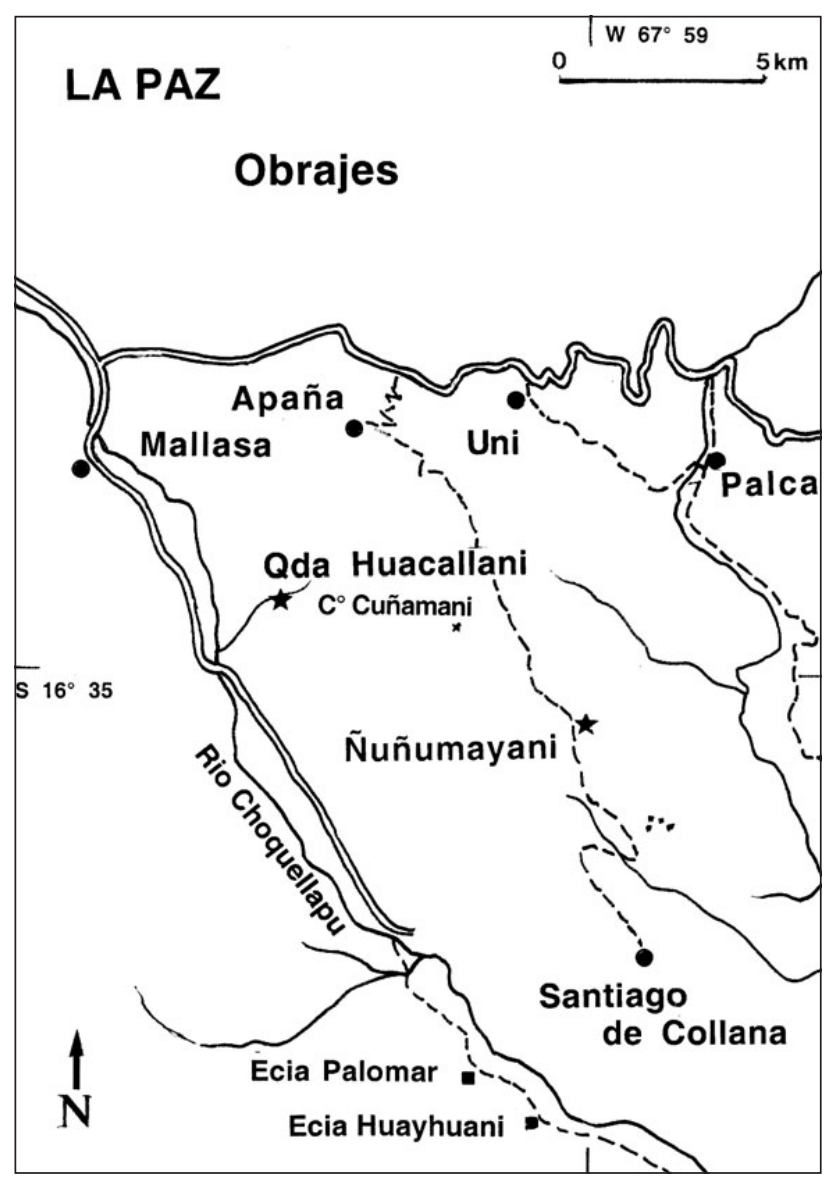

Figure 2. The southeastern region of La Paz Department and the location of the Nuñumayani and Quebrada Huacallani fossiliferous localities.

\section{The road to Muruhuta}

Figures 1, 3

Along the road from Patacamaya to Muruhuta, via Chacoma, Early Devonian sandstones crop out and they are particularly well exposed for $2 \mathrm{~km}$ after the crossroad with the road to Estancia Muru Chapi. The section along the road exposes two interbedded argillaceous intervals which yielded an abundant, tectonically distorted, and low diversity fauna. The first outcrop, named 'Muruhuta 1' (S 1707' 132, W 67'50' 955, altitude $3970 \mathrm{~m}$ ) yields a chonetoidean brachiopod species (Sanjuanetes glemareci sp. nov.) and rare, poorly preserved bivalves. About $300 \mathrm{~m}$ farther on, the outcrop 'Muruhuta 2' (S 1707’ 009, W 6750' 944, altitude $3961 \mathrm{~m}$ ) yields the bivalve Nuculites sp., and brachiopods including Iridistrophia sp., Australocoelia sp., and Sanjuanetes glemareci sp. nov.

These two levels are undoubtedly part of the Muruhuta Shale Member, below the Caracato Quartz Arenite Member in the lowermost part of the Belén Formation (Tiella et al. 1998). The occurrence of a species assigned to the genus Sanjuanetes is suggestive of a late Silurian (Přídolian) age (see below). 


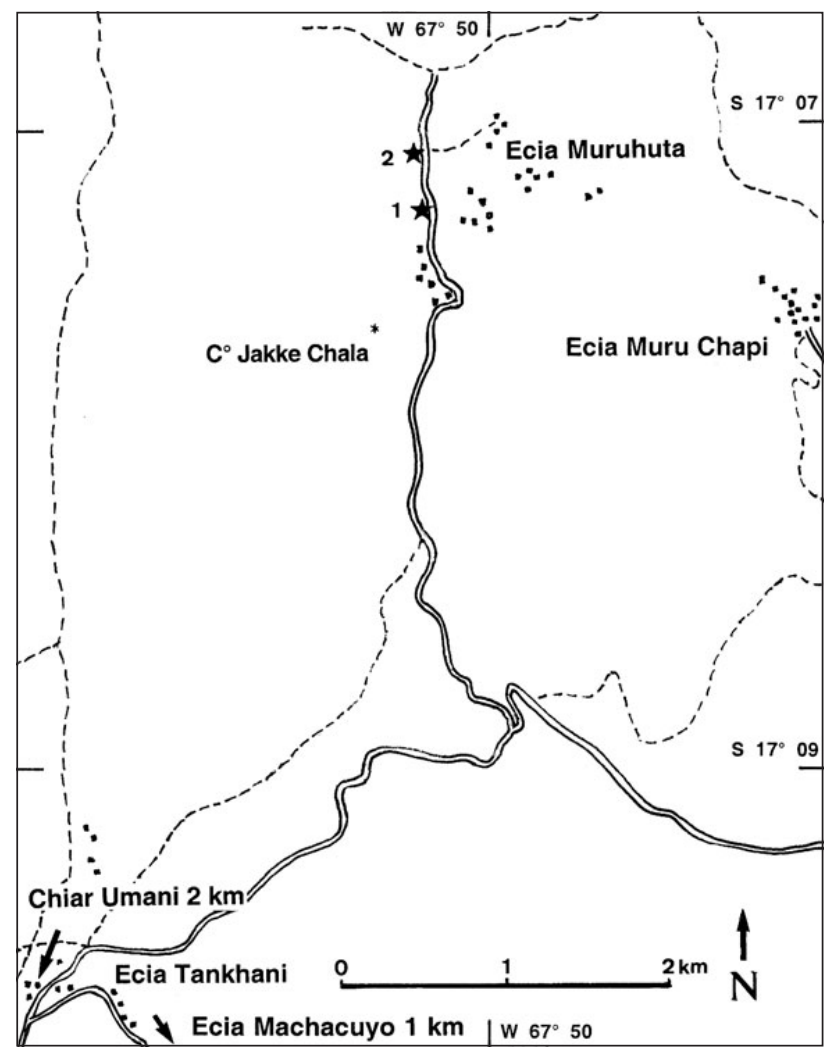

Figure 3. Location of the two Muruhuta localities N-NE of Chiar Umani.

\section{The Quebrada Huacallani locality}

Figure 2

Situated S of La Paz and W of Nuñumayani, this fossiliferous locality of the Uncía Formation was recently sampled and studied by Toro et al. (2003, 2006, 2008). Coordinates are $\mathrm{S} 16^{\circ} 35^{\prime} 02$ ? - W $68^{\circ} 04^{\prime} 30$ ?; for the location map see also Toro et al. $(2006,2008)$. The trilobite and bivalve faunas led the author to assign a Wenlockian age to the sampled beds. Although the locality was not studied in the context of the field work program described herein, it is included in this paper for comparison with other localities (mainly Ñunumayani and Muruhuta) for biostratigraphy and correlation purposes. Besides bivalves, the section provided us with Sanjuanetes sp. cf. S. glemareci sp. nov., which is close to the chonetidean species from Muruhuta, and trilobites close to those from Nuñumayani. Palynomorphs (acritarchs and chitinozoans) are mostly suggestive of a Přídolian age.

\section{The Pisacaviña area}

Figures 1, 4, 5

The locality name Pisacaviña is famous for a long time since it was synonymous with the unique known occurrence of Bolivian Devonian corals within the Bélen Formation. Pisacaviña is located about $22.5 \mathrm{~km}$ E of Calamarca which is about $60 \mathrm{~km} \mathrm{~S}$ of La Paz, along the La Paz - Oruro main road (Fig. 1). The historical fossiliferous locality which yielded corals (Fig. 4-1; S $16^{\circ} 54^{\prime} 166$ - W 68 $03^{\prime} 767$, altitude $4556 \mathrm{~m}$ ) disappeared with the excavation of the area for the football field at the end of the 1980s. A second outcrop exposing corals was visited for the first time in 2005 (Fig. 4-2; S 16 54' 412 - W 68 $03^{\circ} 248$, altitude $4515 \mathrm{~m}$ ). The corresponding lithologic succession in the Pisacaviña area, including the two fossiliferous localities mentioned herein is tentatively reconstructed (Fig. 5).

Although no more coral fragments can be collected at the 'historical' locality, the silts croping out along the SW margin of the football field yield abundant fossiliferous concretions. A relatively large (15 cm in diameter), decalcified and weathered nodules collected in situ provided us with the ostracod fauna described below. A small siliceous nodule from the same level yielded a nicely preserved mandible of a phyllocarid crustacean. The fauna collected from the outcrop along the margin of the football field includes the conularid Paraconularia ulrichana (Clarke, 1913), fragments of a very large hyolithid shell, tentaculitids, 'auloporid-like' tabulate corals fragments, brachiopods [Metaplasia pseudoumbonata (Kozlowski, 1923), Aseptonetes isaacsoni Racheboeuf \& Branisa, 1985, Longispina riglosi Racheboeuf \& Isaacson, 1994, Chonostrophia sp. cf. C. truyolsae, Pustulatia sp. cf. P. curupira (Rathbun, 1874)], gastropods (Palaeozygopleura sp., pleurotomariids), and isolated crinoid ossicles. Among the arthropods are trilobite fragments and an isolated phyllocarid mandible most probably belonging to Dithyrocaris sp. Vertebrate remains are represented by the chondrichtyan Pucapampella cf. P. rodrigae Janvier \& Suárez-Riglos, 1986.

About $120 \mathrm{~m}$ southward, and about $25-30 \mathrm{~m}$ higher in the succession, there is a trilobite bearing bed of nodules that include phyllocarids, vertebrates, and the first and unique fragment of the plant Protolepidodendron, the first collected from South America. Phyllocarid crustaceans are represented by a carapace fragment of a probable new taxon, while vertebrate fossils are assigned to Pucapampella cf. P. rodrigae Janvier \& Suarez-Riglos, 1986 (chondrichtyan), Zamponiopteron triangularis Janvier \& Suárez-Riglos, 1986 and Z. spinifera Janvier \& SuárezRiglos, 1986 (gnathostomes incertae sedis, probable chondrichtyans).

The second Pisacaviña fossiliferous locality was visited during the 2005 period because of inhabitants of Pisacaviña who directed our attention to it. The outcrop lies about $1.0 \mathrm{~km}$ ENE of the football field and E of the Pisacaviña village (coordinates: S 16 $54^{\prime} 412$ - W 68 $03^{\circ}$ 248). A carbonate lens about $3 \mathrm{~m}$ wide and $0.50 \mathrm{~m}$ thick is exposed along a slope within the siltstones of the Belén Formation 


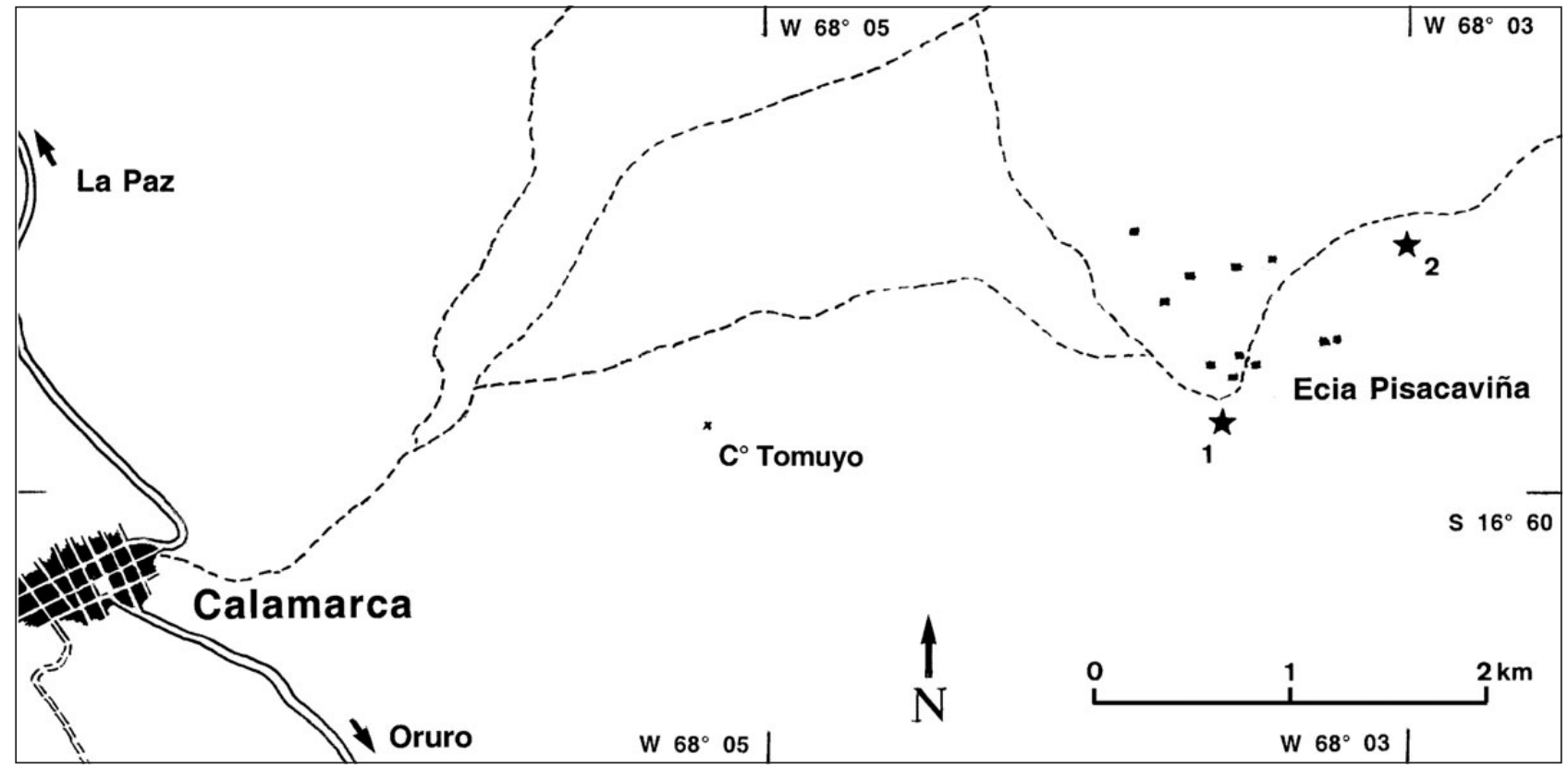

Figure 4. Location of the two Pisacaviña coral-bearing localities E of Calamarca: 1 - 'historical' locality; 2 - locality visited in 2005.

(see Fig. 5). Corals are not preserved in situ, and fragments lie on bedding planes, associated with abundant and poorly preserved crinoid fragments. Limestones are weakly dolomitized. No faunal components but crinoid remains were found associated with the corals.

The fauna collected from the 'historical' locality at Pisacaviña, mainly brachiopods and vertebrates, show very close affinities with that collected in the Chiar Umani Cha Chacoma area about $8 \mathrm{~km} \mathrm{NE}$ of Patacamaya (Racheboeuf \& Issacson 1994, Fig. 1). A Middle Devonian age (Eifelian) appears likely for the outcrops of Pisacaviña, according to palynomorphs (see below).

\section{The Rumicorral area}

Figure 1

Although it belongs to the Kirusilla Formation of the Interandean Zone, this locality is included in this work both for biostratigraphy and correlation with the Eastern Cordillera Uncía Formation. Situated at $22.7 \mathrm{~km}$ E of the gas station of Aiquile, along the old road from Cochabamba to Santa

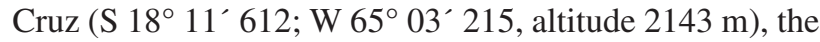
Rumicorral locality is mainly famous as the type locality of the xiphosurid Legrandella lombardi Eldredge, 1974. However, some hundred meters N of this type locality, fossiliferous levels of the Kirusilla Formation provided us with abundant and diversified faunal elements. The northern part of the outcrop (closest to the southern side of the road) exposes dark grey shales and silts with rare small siliceous nodules yielding lingulate and orthid brachiopods,

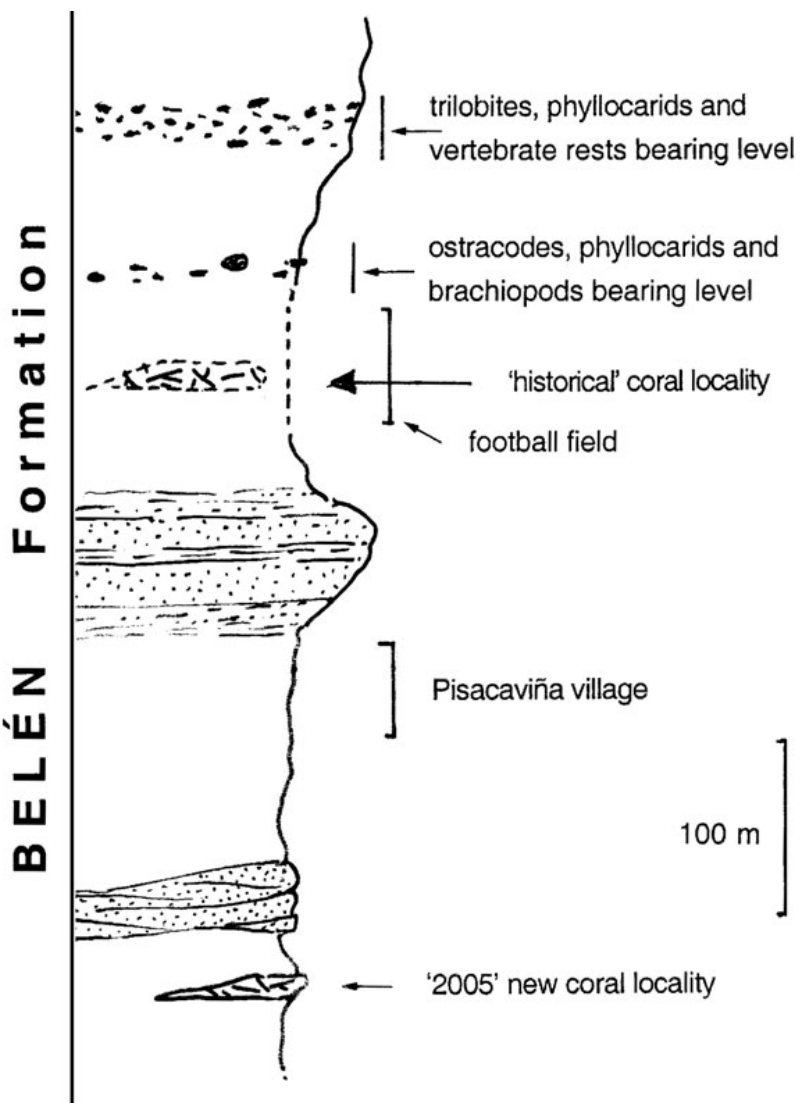

Figure 5. A - schematic reconstruction of the Devonian lithostratigraphic succession of the Belén Formation in the surroundings of the Pisacaviña village, with the relative position of the historical (1) and newly discovered (2) coral outcrops within the succesion. $\bullet \mathrm{B}-$ the coral level visited in 2005 . 
bivalves, gastropods, phyllocarids, and rare vertebrate fossils. To the south, the siliceous nodules are replaced by carbonated nodules, possibly corresponding to mud pebbles which have agglutinated fossils etc., and/or channel infillings (?). The fauna includes chitinous tubes (Sphenothal$l u s$ ), conularids, tentaculitids, gastropods, bivalves, nautiloid cephalopods, diverse brachiopods, poorly preserved ostracods, phyllocarids, and odontopleurid trilobites. Palynological data (acritarchs and chitinozoans) indicate a Lochkovian age.

\section{Palynological data (Alain Le Hérissé \& Florentin Paris)}

Figures 6, 7

In each of the fossiliferous localities studied herein, samples were collected for palynological analyses in order to establish the ages suggested by the benthic faunal elements within the Late Silurian-Early Devonian succession. However, the organic matter is most often weathered in field samples on the Altiplano, and palynological data remain uncertain, waiting for further analyses, and for SEM studies. Acritarchs and chitinozoans are illustrated on Figs 6 and 7, respectively. Palynological analyses of two other fossiliferous localities, namely Rumicorral and Huacallani, have also been made in order to discuss correlations.

\section{Ñuñumayani}

Acritarchs are abundant and diverse but poorly preserved. Most of the specimens are flattened, partly carbonized and corroded. Identified species include Arkonia nova, fragments of Deflandrastum sp., Cymbosphaeridium cariniosum, Elektoriskos spp., Eupoikilofusa striatifera, Geron amabilis, Leiofusa banderillae, L. fusiformis, Multiplicis- phaeridium polydactylus, Polyplanifer simplex, Pterospermopsis spp., abundant specimens of the form-group Onondagaella-Triangulina, with Onondagaella assymmetrica (large forms), Triangulina cylindrica, Ozotobrachion palidodigitatus, $O$. sp., and simple sphaeromorphs and veryhachids. The species Arkonia nova is relatively well represented in the material. This taxon is sometimes referred in the literature as a triangular variant of Neoveryhachium carminae, e.g. in Spain near the Siluro-Devonian transition (Cramer \& Rodríguez 1977), or as ?Striatotheca scabrata in an acritarch flora of late Silurian-early Devonian age, in the Netherlands (Van Der Meer \& Wicander 1992). The total range of the species is from the Ludlow-Přídolí transitional beds up to the Siluro-Devonian boundary. On the basis of the stratigraphic distribution of the most significant acritarch species, e.g. Arkonia nova (introducued by Le Hérissé 2002), Deflandrastum spp., and the Ozotobrachion represented, but also to the absence of definitive Devonian species, a probable Prrídolian age is suggested. However, Triangulina cylindrica, Geron amabilis, and Polyplanifer simplex are not restricted to the late Silurian but continue in the Lochkovian. For example, Polyplanifer simplex described by Pöthe de Baldis (1975) in the Ludlow of Argentina, also extends into the Lochkovian of the Boomerang area (Le Hérissé, unpublished data) and in the Solimóes Basin of northwestern Brazil (Rubinstein et al. 2008).

The chitinozoa assemblage is fairly diversified, including Cingulochitina ervensis (Fig. 7I), small specimens of Ancyrochitina close to A. asterigis, another one similar to Ancyrochitina floris (Fig. 7L) from the Přídolí of Libya, and some desmochitinids which could be possibly assigned either to Eisenackitina bohemica (Lochkovian), or to Eisenackitina granulata (Late Ludlow). Moreover, a Pterochitina with a wide carina could be possibly assigned to $P$. perivelata (late Silurian) (Fig. $7 \mathrm{M}$ ), rather than to $P$. megavelata from the early Lochkovian.

Figure 6. Acritarchs. The illustrated specimens of acritarchs are stored in the collections of the Laboratory of Paleontology, University of Brest (France) under the repository numbers LPB 13061 to 13066. The England Finder coordinates are given in parentheses. • A - Estiastra sp. 1. Pisacaviña, a small form of $29 \mu \mathrm{m}$ in diameter, with eight conical processes, $6 \mu \mathrm{m}$ in length, slide LPB 13061 (028.2). • B, C - Estiastra exasperata (Deunff, 1955) nov. comb. Pisacaviña; B - specimen with a total diameter of $60 \mu \mathrm{m}$, length of processes $25 \mu \mathrm{m}$, slide LPB (6) (Q34.2), C - a specimen with a total diameter of $67 \mu \mathrm{m}$, processes $17 \mu \mathrm{m}$ in length, slide LPB 13062 (L27.1). • C - Estiastra exasperata (Deunff, 1955) nov. comb. Pisacaviña, total diameter $60 \mu \mathrm{m}$, length of processes $25 \mu \mathrm{m}$, slide LPB 13061 (Q34.2). • D - Estiastra sp. 2. Pisacaviña, a form with five processes, conical, with spinose ornamentation. Total diameter $48 \mu \mathrm{m}$, process length $20 \mu \mathrm{m}$, slide LPB 13062. • E - Leiofusa bernesgae Cramer, 1964. Rumicorral, central body $30 \times 12 \mu \mathrm{m}$, length of processes $40 \mu \mathrm{m}$, slide LPB 13064 (J29). $\bullet \mathrm{F}-$ Neoveryhachium carminae (Cramer) Cramer, 1970. Rumicorral, central body $22 \times 15 \mu \mathrm{m}$, length processes $8 \mu \mathrm{m}$, slide LPB 13063 (N28.1). • G - Fimbriaglomerella divisa Loeblich \& Drugg, 1968. Rumicorral, total diameter 50 $\mu$ m, slide LPB 13063 (P22). $\bullet$ H - Quadraditum fantasticum Cramer, 1964. Rumicorral, total dimensions $45 \times 22 \mu \mathrm{m}$, flange $22 \mu \mathrm{m}$ of width, slide LPB 13064 (D26.2). $\bullet$ I - ?Domasia sp. Rumicorral, central body $22 \times 9 \mu \mathrm{m}$, length of processes $22 \mu \mathrm{m}$, slide LPB 13064 (K 19.3). • J - Triangulina cylindrica (Jardiné, Combaz, Magloire, Peniguel \& Vachey, 1972) comb. nov. Nuñumayani, central body $33 \mu \mathrm{m}$, length of processes $22 \mu \mathrm{m}$, slide LPB 13065 (S 44.2$)$. K - Arkonia nova Le Hérissé, 2002., central body $33 \mu \mathrm{m}$, Lp 5-6 $\mu \mathrm{m}$, slide LPB 13065 (O 38). • L - Cymbosphaeridium cariniosum (Cramer) Jardiné, Combaz, Magloire, Peniguel \& Vachey, 1972. Ñuñumayani, central body $35 \mu \mathrm{m}$, Lp 5-6 $\mu \mathrm{m}$, slide LPB 13066 (O 24). • M - Geron amabilis Cramer, 1969. Nuñumayani, central body $17 \mu \mathrm{m}$, Lp $6 \mu \mathrm{m}$, slide LPB 13065 (D 28.1). - N - Polyplanifer simplex Pothe de Baldis, 1975. Nuñumayani, central body $17 \mu \mathrm{m}$, Lp $6 \mu$ m, slide LPB 13065 ( E 25). $\bullet$ O - Ozotobrachion palidodigitatus (Cramer) Playford, 1977. Nuñumayani, central body $22 \mu \mathrm{m}$, length of processes $35 \mu$ m, slide LPB 13065 (R25.4). 

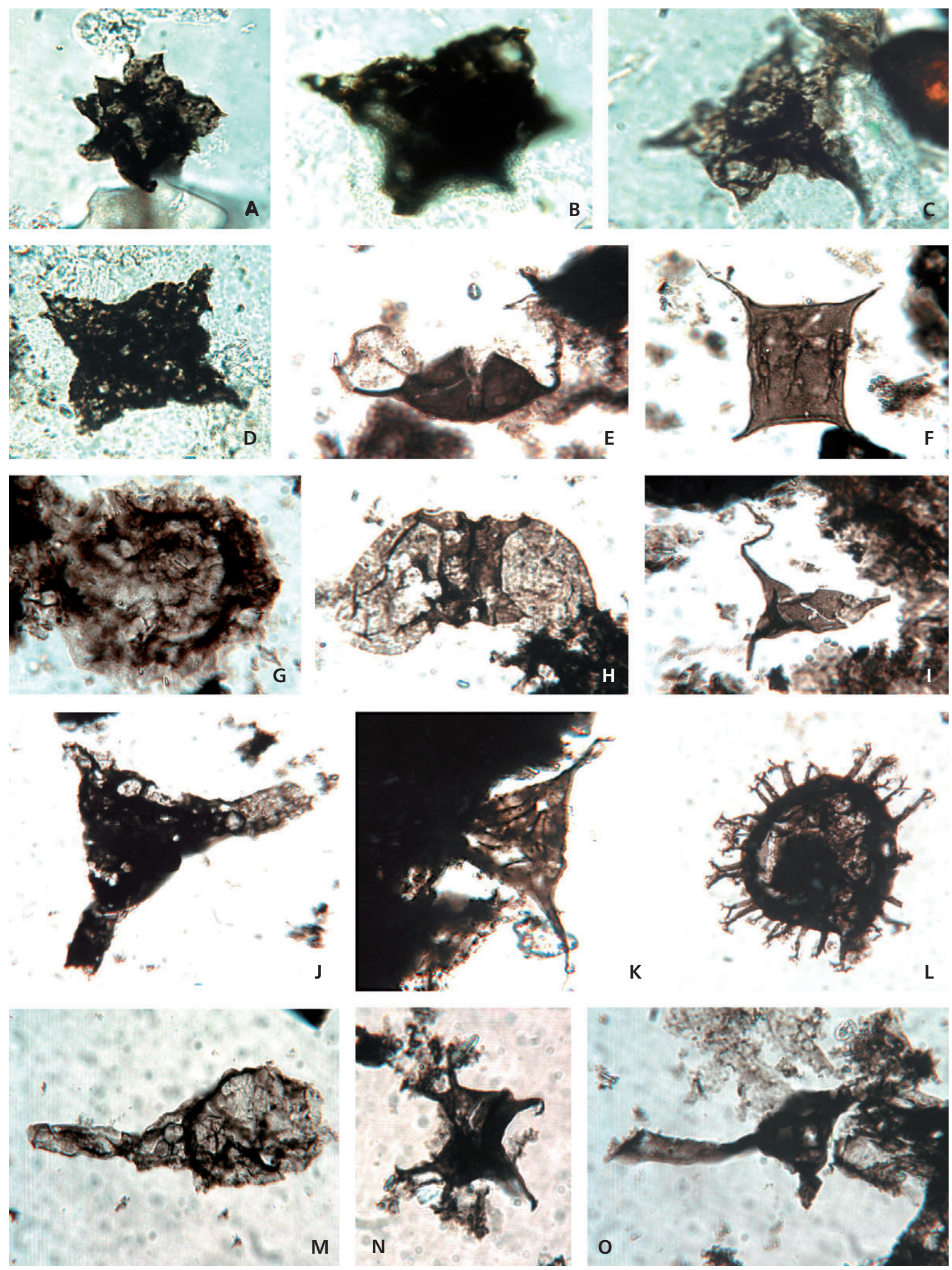


\section{Muruhuta}

The two outcrops named Muruhuta 1 and Muruhuta 2 provided us with poorly preserved chitinozoans and a low diversity acritarch assemblage. The acritarch assemblage includes Cymbosphaeridium cariniosum, Onondagaella assymmetrica, Triangulina alargada, and simple forms of Multiplicisphaeridium and Veryhachium. Such forms are suggestive of a late Silurian age taking into account the absence of typical Early Devonian forms.

The two samples provided us with poorly preserved chitinozoan specimens among which representatives of Angochitina sp. (several forms), Ancyrochitina cf. desmea (Fig. 7A), Conochitina sp., Linochitina sp., Fungochitina sp., ?Urnochitina sp. aff. U. urna (Fig. 7E) and a possible representaive of the genus Margachitina. The occurrence of U. urna and Conochitina would indicate a Late Silurian, ?Ludlovian or Přídolian age.

\section{Pisacaviña}

Four samples were collected from the Pisacaviña section. Samples from the new coral-bearing locality provided us with no palynomorphs: there were only graphite and heavy minerals. Samples from the 'historical' locality revealed very dark and corroded organic elements composed of miospores, acritarchs and chitinozoa.

Examination of several slides provided us with only few diagnostic elements and few specimens of acritarchs, that would provide precise determinations. The presence of the small genus Estiastra allows correlation with similar assemblages and levels of the Middle Devonian (close to the Eifelian-Givetian boundary) or at the youngest Emsian to Eifelian (Pothe de Baldis 1978, from Uruguay, and Le Hérissé, unpublished data from Bolivia).

Chitinozoa are represented by the lagenochitinid Ancyrochitina sp. (belonging to the A. biconstricta group but smaller in size), associated with velate spores which begin within the late Emsian and become abundant from the Middle Devonian. The assemblage is most probably indicative of a Middle Devonian (Eifelian) age.

\section{Rumicorral}

Acritarchs include Cymbosphaeridium cariniosum, C. sp., ?Domasia sp., Duvernaysphaera oa, Eupoikilofusa striatifera, Fimbriaglomerella divisa, Hapsidopalla sp., Leiofusa bernesgae (abundant), L. cylindrica, Neoveryhachium carminae, Polyplanifer simplex, Quadraditum fantasticum, and abundant Veryhachium spp. The relative abundance of leiofusids, and especially that of Leiofusa bernesgae, is characteristic of the Zudañeziano stage (Early Devonian) of the 'Cordillerano Cyclo' as defined by Suárez-Soruco \& Lobo-Boneta (1983). Moreover, Fimbriaglomerella divisa, Duvernaysphaera $o a$, and ?Domasia sp. have been also found elsewhere in Bolivia in the Lochkovian. The two species Duvernaysphaera oa and Fimbriaglomerella divisa were first described from the Lochkovian of the Haragan Formation, Oklahoma, North America (Loeblich \& Wicander 1976, Wicander 1986). Associated with ?Domasia sp., they are also diagnostic species of Lochkovian assemblages in other localities in Bolivia (Le Hérissé, unpublished data).

The chitinozoan assemblage includes Cingulochitina gr. serrata (Fig. 7D), Linochitina sp., and Ancyrochitina asterigis (Fig. 7F). Eisenackitina sp. aff. bohemica (Fig. 7C), and E. gr. bohemica (Fig. 7H) and suggest Lochkovian age. Rare representatives of Pterochitina may possibly be assigned to $P$. megavelata (Fig. $7 \mathrm{G}$ ), which is mainly early Lochkovian. Rare specimens of Urochitina loboi Volkheimer et al., 1986 (Fig. 7J, K), a Lochkovian species, occur too. As a conclusion, both chitinozoan and acritarchs indicate a Lochkovian age.

Figure 7. Chitinozoans. The illustrated chitinozoans are stored in the collections of the Institute of Geology, University of Rennes (France) under the repository numbers IGR 72525 to 72540 . The England Finder coordinates is given in parentheses. The scale bar equals 100 microns. A - Ancyrochitina cf. A. desmea Eisenack, 1964. Muruhuta section, loc. 2, IGR 72530 (M44/3). • B - ?Urnochitina sp. Muruhuta section, loc. 2, IGR 72530 (O47/1). Eroded individuals also recalling some Siluro-Devonian Eisenackitina forms. • C - Eisenackitina sp. aff. E. bohemica (Eisenack, 1934). Rumicorral, IGR 72525 (G46). The ornamentation is deeply eroded, preventing a firm assignment to E. bohemica. • D - Cingulochitina gr. serrata (Taugourdeau \& de Jekhowsky, 1960). Rumicorral, IGR 72525 (G50/1). This form recalls individuals of C. plusquelleci Paris 1981 of Lochkovian age. • E - ?Urnochitina sp. aff. U. urna (Eisenack, 1934). Muruhuta section, loc. 1, IGR 72529 (N43/4). Poorly preserved vesicle. • F - Ancyrochitina asterigis Paris 1981. Rumicorral, IGR 72525 (H42). $\bullet \mathrm{G}$ - Pterochitina megavelata Boumendjel, 2002. Rumicorral, IGR 72525 (R53/4). The carina of this specimen is partly folded at its distal end. $\bullet$ H - Eisenackitina gr. bohemica (Eisenack, 1934). Rumicorral, IGR 72525 (G46). Specimen with a deeply eroded surface no longer showing the typical ornamentation of the species. • I - Cingulochitina ervensis (Paris in Babin et al., 1979). Nuñumayani, IGR 72540 (G47). - J, K - Urochitina loboi Volkheimer, Melendi \& Salas, 1986. Rumicorral, IGR 72525 (T42/2 and M44/3). • L - Ancyrochitina cf. A. floris Jaglin, 1986. Ñuñumayani, IGR 72540 (L/42/2). • M - Pterochitina perivelata (Eisenack, 1937). Nuñumayani, IGR 72540 (R48). • N, O - Angochitina sp. aff. A. comosa Taugourdeau \& de Jekhowsky, 1960. Huacallani, IGR 72537 (P41/1 and P43/4). • P - Margachitina catenaria? Obut, 1973. Huacallani, IGR 72537 (P40/4). Apical view showing remains of a possible peduncle. $\bullet$ Q - ?Ramochitina sp. Huacallani, IGR 72537 (P43/1). Deeply eroded surface displaying some scars of apparently large processes more or less arranged in rows, and suggesting an assignment to Ramochitina. 
Patrick R. Racheboeuf et al. - Silurian and Devonian palaeontology and biostratigraphy of Bolivia

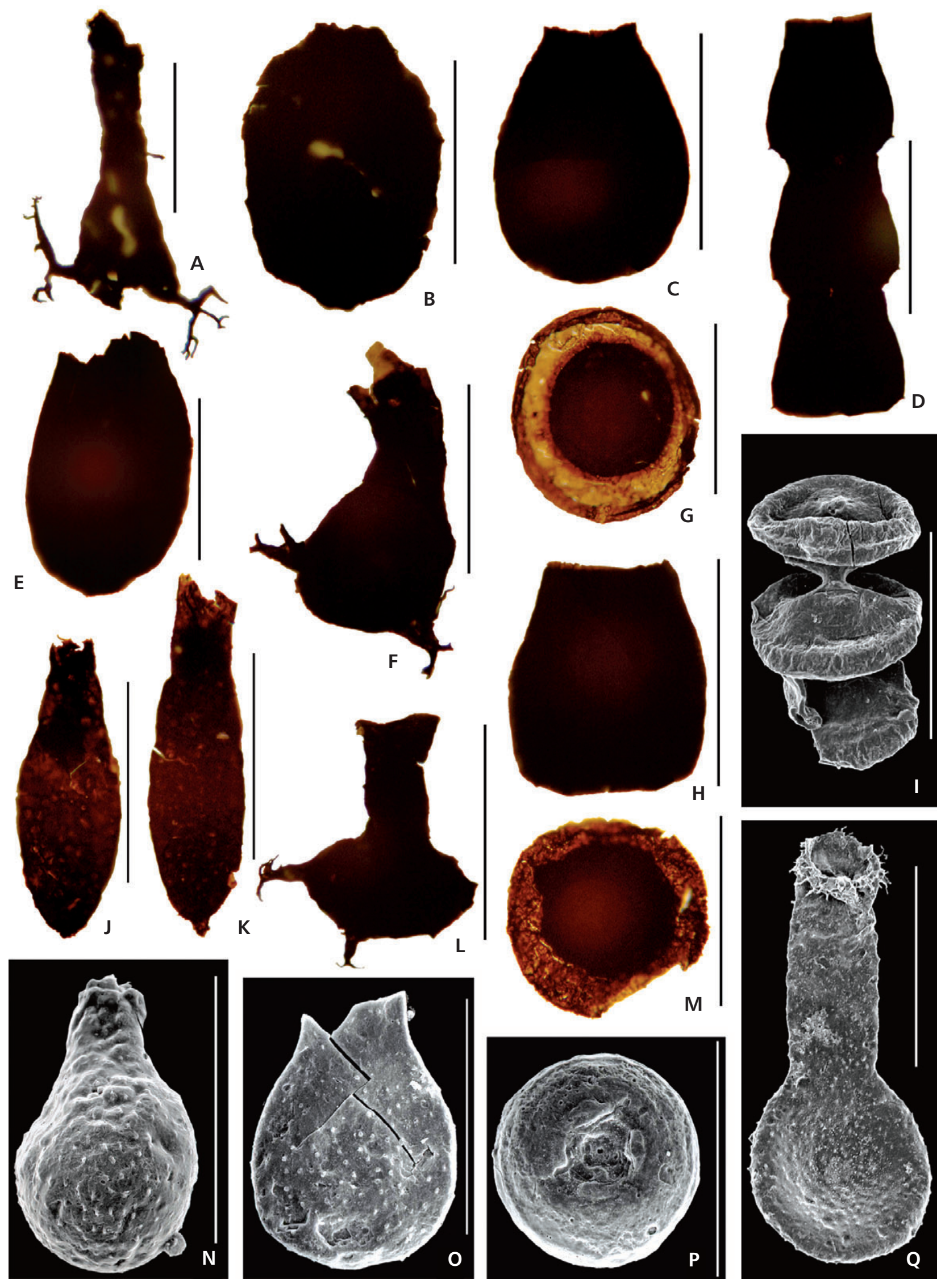




\section{Huacallani}

A unique sample from this locality situated W of Ñunumayani, which provided us with a unique ventral valve of Sanjuanetes cf. S. glemareci sp. nov., was analyzed for palynology purpose. The palynological residue contained various marine and continental palynomorphs, including acritarchs, prasinophycean phycomata, chitinozoa and miospores. Acritarchs and prasinophytes from the recovered assemblage are of poor diversity. Among the most diagnostic species are Fimbriaglomerella aulerca, Hapsidopalla sannemannii, ?Multiplicisphaeridium escobaides, Oppilatala cf. O. arborea, indicating an early Devonian age, Lochkovian to Pragian (Le Hérissé et al. 2000). Among miospores, numerous representatives of the genus Dictyotriletes are observed. In the Laurani section of Bolivia (Tarabuco area), McGregor (1984) described within the Santa Rosa Formation of Lochkovian to Pragian age a palynoflora that includes specimens of Dictyotriletes emsiensis. They are now included in the Dictyotriletes emsiensis Morphon, which is tentatively correlated with the $\mathrm{N}$ through $\mathrm{E}$ miospore biozones of W Europe, Lochkovian to early Pragian in age ( $\mathrm{Ru}-$ binstein et al. 2005, Steemans et al. 2008).

Chitinozoans are abundant and fairly well preserved. The chitinozoan assemblage includes five species, but none of them is really significant from a biostratigraphical point of view. The most common form is Angochitina sp. aff. A. comosa which is close both to Angochitina strigosa and $A$. filosa from the Lochkovian of Algeria (Boumendjel 1987). A. sp. aff. A. comosa also strongly resembles A. echinata from the Tarabuco Formation (Rio Pillaya section) of Bolivia (Grahn 2002). The genus Margachitina is represented by M. sp. aff. M. catenaria catenaria. Similar specimens are known from the Early Lochkovian of Algeria (Boumendjel 1987), and Margachitina catenaria tenuipes was reported from the Santa Rosa Formation (Sobo Sobo section) of Bolivia (Grahn 2002). Besides representatives of the genera above mentioned, the chitinozoan assemblage includes specimens assigned to the genus Cingulochitina, and which resemble $C$. ervensis (Přídolian-Lochkovian of Europe), and Ancyrochitina sp. aff. A. cornigera; similar specimens are known from the Lochkovian of Poland (Wrona 1980).

On the basis of the chitinozoan assemblage alone a Lochkovian age appears likely despite the lack of the index species (Eisenackitina bohemica). Late Přídolian age cannot be excluded although the Přídolian index species (Urnochitina urna) was not found.

\section{Systematic palaeobotany (Jean Broutin)}

According to the literature, this is the first occurrence of a plant macrorest in the Lower/Middle Devonian of Bolivia, and the first record of the genus Protolepidodendron from South America.

Family Protolepidodendraceae Kräusel \& Weyland, 1949

\section{Genus Protolepidodendron (Krejčí, 1879) \\ Potonié \& Bernard, 1904}

Type species. - Protolepidodendron scharianum (Krejčí) Potonié \& Bernard, 1904, Lower Devonian, China (Yunnan).

Geographic distribution. - Early Devonian of Yunnan (China); Middle Devonian of Europe, North America, and Australia (Boureau 1967, pp. 455-457). Boureau (ibid., p. 458), cited also a species (unfigured) from the Middle Devonian of San Juan (N. Argentina): Protolepidodendron eximium Frenguelli, 1954 initially described as 'Drepanophycus frenguelli (Frenguelli) Menendez 1965'. This Bolivian occurrence is the first established record of the genus from South America.

\section{Protolepidodendron sp.? aff. Protolepidodendron scharianum (Krejčí, 1879) Potonié \& Bernard, 1904 Figure 8A-C}

Material and locality. - A unique fragment (FCGI 3571, Fig. 8), part and counterpart, from the locality Pisacaviña, collected in a trench, about $100 \mathrm{~m} \mathrm{SE}$ of the football field (S 16 54 090; W 68 00` 804); Belén Formation, probable Eifelian.

Description. - Small stalk fragment which is $24 \mathrm{~mm}$ long for a width of $7 \mathrm{~mm}$ at the base. Its width reaches $12 \mathrm{~mm}$ at the level of the dichotomy which gives rise to two ramifications which are respectively $5 \mathrm{~mm}$ and $7 \mathrm{~mm}$ wide (Fig. 8). The stalk is densely covered with ovoid leaf cushions which are $1.2 \mathrm{~mm}$ to $1.5 \mathrm{~mm}$ long for a maximum width of $1 \mathrm{~mm}$, and helicoidally arranged. The best preserved leaf cushions exhibit a circular vascular scar in more or less central position.

A single base of a leaf, linear and very narrow (about $0.35 \mathrm{~mm}$ wide), could be observed on the right side of the stalk (indicated by an arrow on Fig. 8C). The leaf is undoubtedly incomplete and it is impossible to say if it was dichotomous or not, and even more, at what distance from its insertion was the eventual dichotomy.

Discussion. - About the genus Protolepidodendron, the main problem is as follows: the very low number of species assigned to this genus are defined upon the length of the leaves, as well as by the location of their dichotomy. The unique available Bolivian specimen shows no more than the base of one leaf (Fig. 8C, arrow) which makes inapplicable the taxonomic character exposed above. 

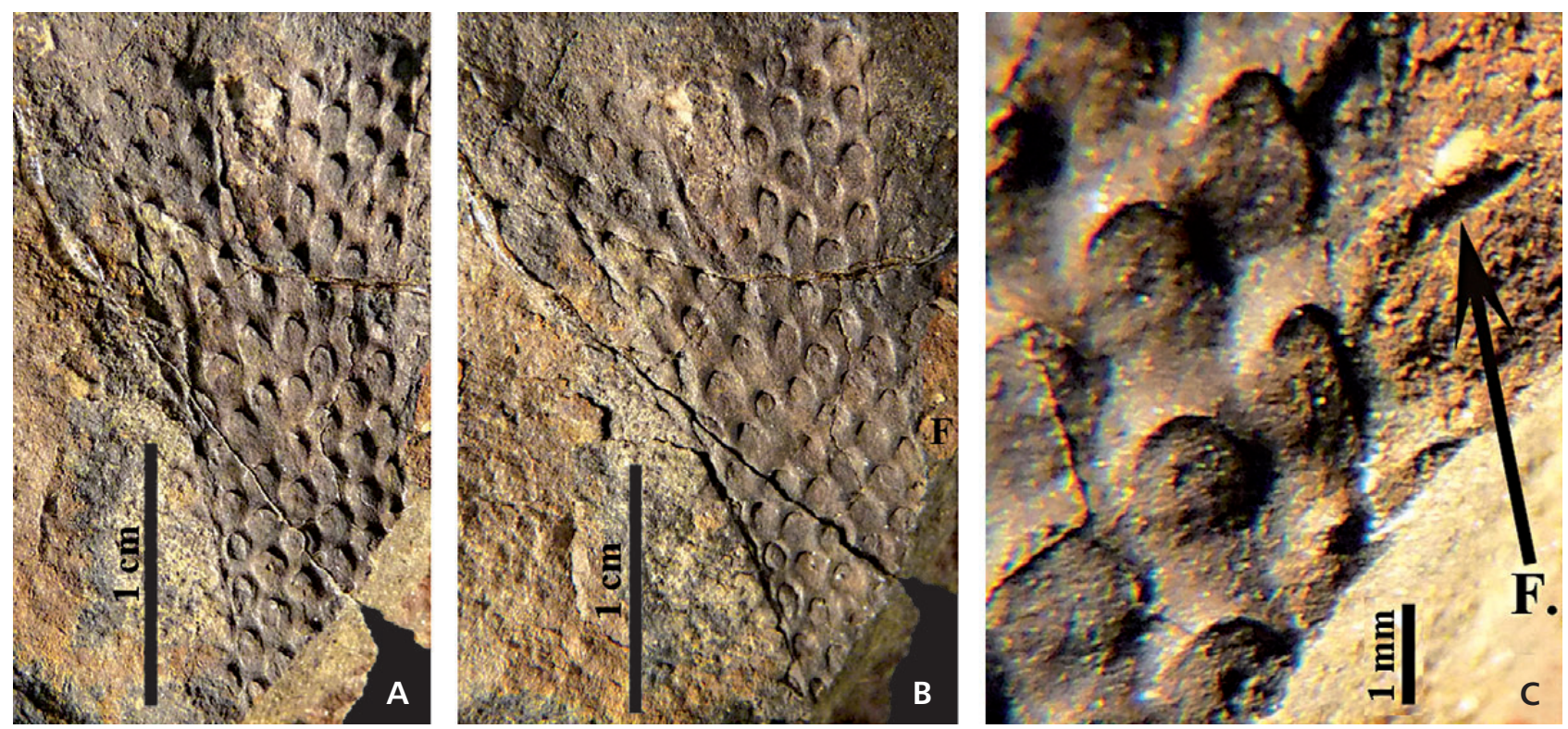

Figure 8. Protolepidodendron sp.? aff. P. scharianum. • A, B - general view of the stalk fragment (FCGI 3571) under two different lights showing leaf cushions and vascular scars. $\bullet \mathrm{C}$ - enlarged view showing the unique preserved base of leaf $(\mathrm{F})$.

However, Lejal-Nicol (1972, pp. 54, 55) figured a specimen from the Devonian of Libya (transitional Pragian-Emsian beds, Murzuk Basin). The arrangment, size, and density of leaf cushions of which strickingly resemble those observed on the Bolivian specimen. Lejal-Nicol described a new species, namely Protolepidodendron helleri Lejal, 1972, based upon the lack of leaves and vascular scars ["...l'absence de feuille et de cicatricules vasculaires" (sic!)]. Seeing the preservation of the specimen (pl. 9, fig. 2), we cannot exclude that such absences are the consequence of the poor preservation of the specimen.

The unique stalk fragment from Bolivia (24 mm long for $12 \mathrm{~mm}$ of maximum width, just below the dichotomy) exhibits an ornament very similar to that of the specimen from Libya (arrangement, size and density of leaf cushions); such characters are very close to that observed in Protolepidodendron scharianum.

\section{Systematic palaeozoology}

\section{Tabulate corals (pleurodictyforms) (Yves Plusquellec)}

The Pleurodictyum-like corals are less common in South America, than in other areas of the Gondwana like N Africa, Ibero-Armorican Domain, and SE Australia, among others. They were generally assigned to Pleurodictyum but the occurrence of that genus is not yet definitely established in South America ('Pleurodictyum? n. sp.' in the Late Emsian of Bolivia; Plusquellec 2007, p. 43). The only species belonging to the genus Petridictyum, and discussed by
Salfeld (1911) as Pleurodictyon (sic) petrii? cannot be supported (see below).

Class Anthozoa Ehrenberg, 1834

Subclass Tabulata Milne-Edwards \& Haime, 1850

Superfamily Favositoidea Dana, 1846

Family Micheliniidae Waagen \& Wentzell, 1886

\section{Genus Petridictyum Schindewolf, 1954}

Type species.- Pleurodictyum petrii Maurer, 1874, from Giessen area, Giessen nappe, Rhenish Moutains (Germany), Emsian.

\section{Petridictyum sp.}

Figure 9A-C

2002 Pleurodictyum. - Toro \& García-Duarte, fig. 2. 2004 Pleurodictyum. - Toro et al., fig. 2.

Material. - 4 poorly preserved, partly silicified specimens, two of them from old collections (FCGI 2765 and FCGI 2855), the others collected by Crasquin \& Racheboeuf in 2009 (FCGI 3569 and FCGI 3570).

Locality and stratigraphy. - Nuñumayani area, SE La Paz (Bolivia), Uncía Formation, likely Lochkovian.

Description. - The following description is mainly based on specimen FCGI 2765 which is the 'best' preserved. The specimen FCGI 2765 is partly broken in its right 

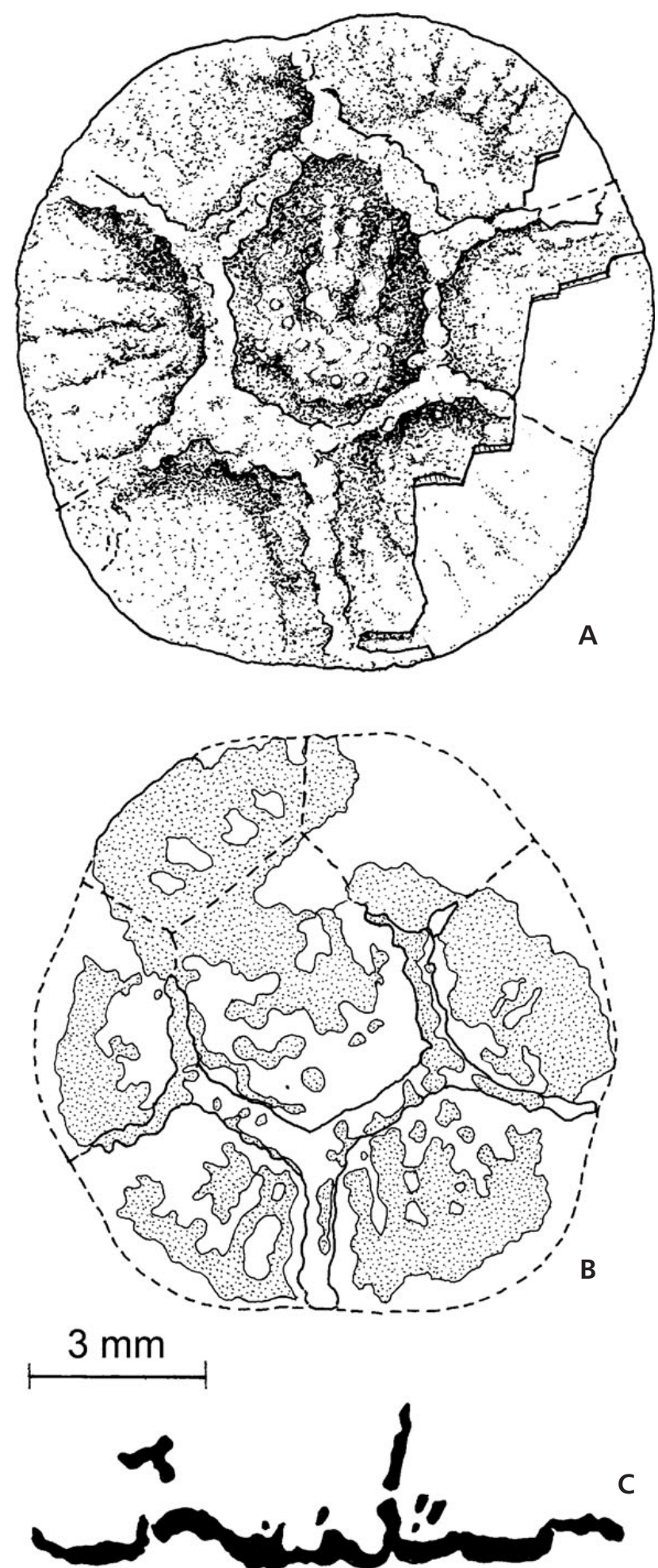

Figure 9. Petridictyum sp., camera lucida drawings. $・$ A - mainly distal side of the corallum; on bottom right, a small area of the natural cast of the proximal side is exposed; apical area on bottom of the figure as usual (see Plusquellec 2007, fig. 2B), FCGI 2765. • B - distal side, dotted area as preserved part of the skeleton, FCGI 3569 . $\bullet \mathrm{C}$ - more or less axial section in the corallum, likely ' $\mathrm{N}-\mathrm{S}$ ' section with apical area on the right, FCGI 3570. latero-apical part and exposes a small area of the natural cast of its proximal side showing prints of some broad radial smooth furrows following the path of the septal ridges (Fig. 9A). Owing to the preservation, the concentric growth ridges of the so-called 'epitheca' are not here visible. An axial section of the corallum, taken in a specimen embedded in black shale, shows an irregular and roughtly convex proximal side (Fig. 9C) while its calicinal (= distal) side is obviously convex. The distal side of the corallum shows a central corallite (protocorallite) surrounded by a corona of 6 (7? in specimen FCGI 2855) metacorallites. The calicinal bottom of the protocorallite bears a spiny convex structure formed from the proximal parts of at least 3 major septal ridges. The calicinal bottom of the metacorallites, and especially their peripheral margin, exhibit 4-5 septal ridges separated by narrow interseptal furrows. They are probably major ridges, but the minor one are not clearly identified. The mural pores are only seen on the sections. The growth form of the corallum belongs to the petrioid type and the prototriad to the contiguous type (see Plusquellec 2007, pp. 27,28$)$.

Measurements. - Diameter of corallum taken in the plane of symmetry (' $\mathrm{N}-\mathrm{S}$ ' diameter) and normal to this plane ('E-W' diameter), respectively $11.5 \times 11.2 \mathrm{~mm}$ (FCGI 2765), $9.6 \times 9.5 \mathrm{~mm}$. (FCGI 3569); height of corallum $c a$ $3 \mathrm{~mm}$ (FCGI 3570); diameter of protocorallite in 'N-S' and 'E-W', respectively $5.4 \times 3.6 \mathrm{~mm}($ FCGI 2765), $5.6 \times$ $4.0 \mathrm{~mm}$ (FCGI 3569); radial diameter of metacorallites mainly between 3 and $4 \mathrm{~mm}$.

Discussion. - The specimens from Nuñumayani show the main morphological features of the genus Petridictyum and are accordingly assigned to it. The radial furrows shown by the proximal side of the corallum are very unusual in Petridictyum but they are already known in $P$. lonsdalii (Rh. Richter, 1855) (Plusquellec et al., unpublished data). The Petridictyum representative described here is a small species with broad septal ridges and narrow interseptal furrows, but its detailed features are insufficiently preserved to try an accurate comparison with the previously described species. However, none of them seems close to it, either by their size or by their septal apparatus.

The occurrence of the genus Petridictyum in the Uncía Formation cannot supply decisive data to the question of its chronostratigraphic assignement, for the genus seems recorded from the Early Silurian to the Early Eifelian.

The oldest form, provisionally assigned to Petridictyum, P. tennesseensis (Amsden, 1949), Middle Llandovery to Early Ludlow of western Tennessee (USA), requires further material to establish if certain characters are consistently maintained (see Plusquellec 2007, fig. 24C; for example, what is the significance of the blind structure in the skeleton 
below the calicinal bottom of the protocorallite in Paratype YPM 20074?). During the Silurian, we also refer to Petridictyum? sp. nov. A (Plusquellec 2007, p. 49, pl. 2, fig. 10) from the Př́idolí of Victoria, Australia, which shows additional metacorallites on the apical side of the first corona and a corallum with a sligtly concave to convex basis (' $\mathrm{N}-\mathrm{S}$ ' corallum diameter about 15 to $16 \mathrm{~mm}$ ).

A Lochkovian form, from Victoria too, seems to be a true Petridictyum; it is a rather large species (' $\mathrm{N}-\mathrm{S}$ ' corallum diameter: $19.5 \mathrm{~mm}$ ) with a strongly convex proximal side and corallites with very numerous septal ridges (Plusquellec 2007, p. 50, pl. 2, fig. 6).

With the late Lochkovian or early Pragian occurrence of P. lenticulare (Hall, 1874), the genus is well known in the Appalachian Basin, USA. It is a large species ('N-S' corallum diameter about $20 \mathrm{~mm}$ ), with corallites bearing numerous septal ridges. More or less about the same time, $P$. casanovai Plusquellec \& Soto, 2007 occurs in the Catalonian Coastal Ranges and in Ossa Morena, Spain. This species is small ('N-S' corallum diameter about 4.5 to $6.2 \mathrm{~mm}$ ) and its septal ridges are broader than the interseptal furrows. The genus is apparently missing during the main part of the Pragian, and becomes common from the early Emsian onwards.

This summary, dealing with the stratigraphic distribution of the genus Petridictyum and the generic assignment of the Silurian representatives (Petridictyum or Petridictyum-like corals) allows some comments:

1. The genus Petridictyum is very scarce and even questionable by Silurian times; this is not in favour of a Silurian age for the Uncía Formation.

2. Whatever will be the chronostratigraphic assignment of the Uncía Formation, it is the first time that an indisputable representative of the genus Petridictyum is recorded from South America.

3. The six specimens described by Salfeld in Hauthal (1911) as Pleurodictyon (sic) petrii? from the Early Devonian of Chacaltaya cannot be assigned to Petridictyum. Preserved in the collection of the Geologisch-Paläontologischen Instituts der Georg-August-Universität, Göttingen, Germany, they share some features with Petridictyum (generally complete corona of metacorallites arround the protocorallite, small number of corallites -9 to 12 , lack of interstitial corallites, Hicetes absent) but: i) the proximal side of the corallum is not clearly convex as usual in Petridictyum, ii) the first corona of metacorallites is always asymmetrical, the corallites of the apical area being much more developed than those of the adapical one, and iii) the corallites of a second corona are already present in the apical area even when the growth of the first one is not finished (see a typical specimen of the species in Plusquellec 2007, pl. 2, fig. 5 = Salfeld 1911, pl. 2, fig. 5). A satisfactory generic assignment for the specimens described in the paper by Salfeld is still needed at the present time, and it is likely a new species.

\section{Tabulate corals (branching forms) (Yves Plusquellec, Francis Tourneur \& Esperanza Fernández-Martínez)}

Prior to the recent publication of a short synthesis by Fernández-Martínez et al. (2007) concerning the present state of knowledge about the tabulate corals of Argentina and Bolivia, Tourneur (1992) recognized the occurrence of Parastriatopora in Bolivia in the Icla Formation at Yaco (Subandean Zone), and in the Belén Formation at Pisacaviña.

According to Branisa (1965), two genera were collected in Pisacaviña: Striatopora cf. S. missouriensis Meek \& Worthen, 1868 (Branisa, pl. 48, figs 2-13) = Parastriatopora Sokolov, 1949, and Striatopora sp. (Branisa, pl. 48, fig. 14) = Thamnoptychia Hall, 1876 (Tourneur et al. 2000, p. 723). However, as the stratigraphic and geographic data pertaining to the specimens collected by Branisa are not reliable, the first part of this paper will only consider the material collected by Janvier \& Gagnier in the 'historical' coral locality (1986), and that collected by Janvier \& Racheboeuf in the new '2005' coral locality (Figs 1, 4, 5). A short description and some figures of Branisa's specimens are given at the end of this chapter.

A large part of the Branisa's collection from Bolivia, including figured specimens, is housed in the National $\mathrm{Mu}-$ seum of Natural History, Smithsonian Institution, Washington D.C. We were permitted to borrow 11 specimens assigned by Branisa to Striatopora cf. S. missouriensis, most of them belonging to Parastriatopora boliviana sp. nov. One of the figured specimens is described here as $P$. sp. 1 cf. $P$. boliviana sp. nov., while three branches of Parastriatopora sp. have not been included in this study. According to Branisa (1965, pl. 48) all these specimens are from the locality Pisacaviña ('Pisakaviña', sic).

Class Anthozoa Ehrenberg, 1834

Subclass Tabulata Milne-Edwards \& Haime, 1850

Superfamily Pachyporoidea Gerth, 1921

Family Parastriatoporidae Sokolov, 1949

\section{Genus Parastriatopora Sokolov, 1949}

Type species. - Parastriatopora rhizoides Sokolov, 1949, from Podkamennaya Tunguska River, Siberian Platform, Llandovery.

\section{Parastriatopora boliviana sp. nov.}

Figures 10-22

1965 Striatopora cf. S. missouriensis Meek \& Worthen, 1868. - Branisa, pl. 48, figs 2-5, 7-13.

1992 Parastriatopora gigantea (Knod, 1908). - Tourneur, p. 47, unnumbered figure. 

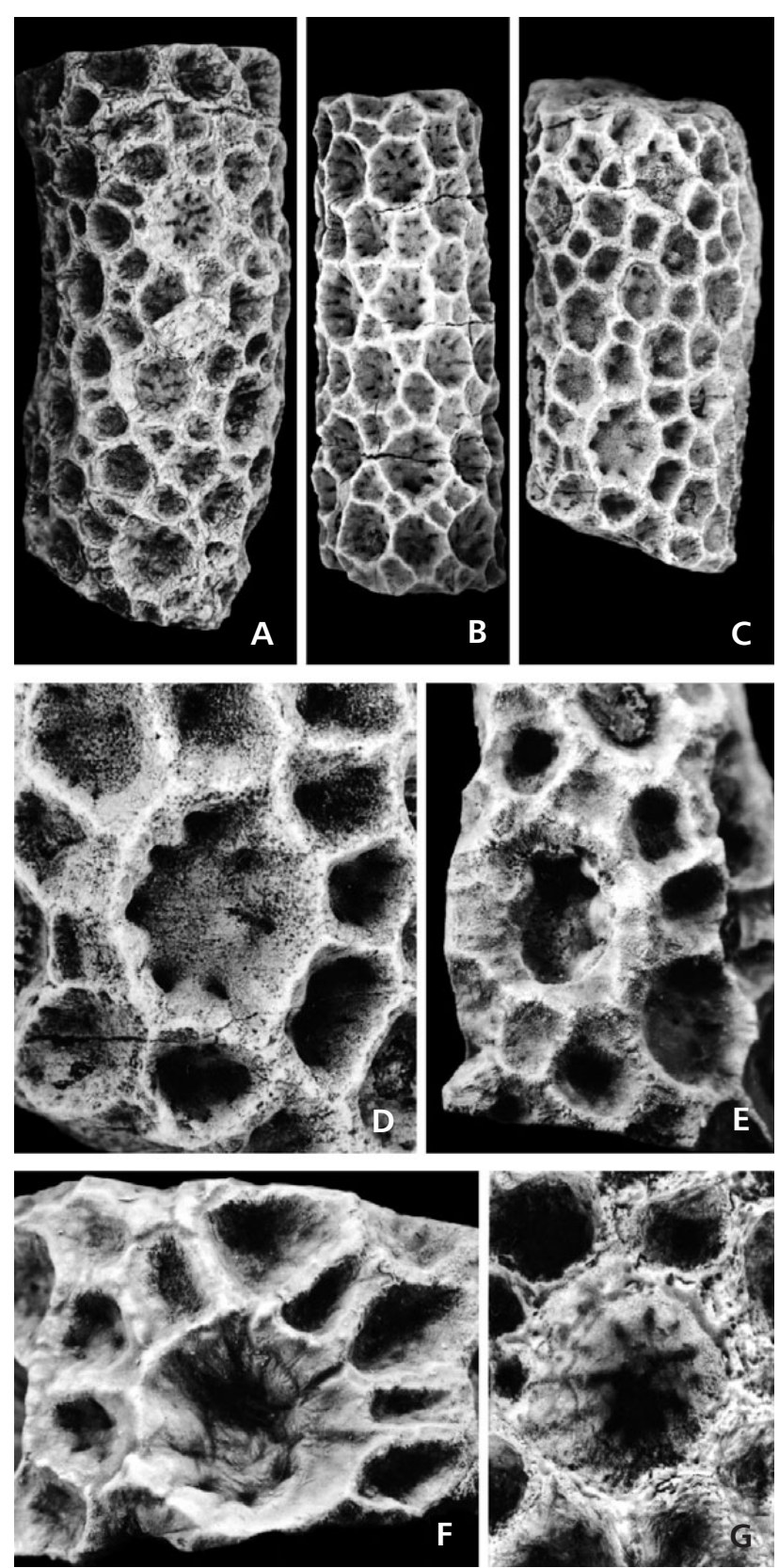

Figure 10. Parastriatopora boliviana sp. nov. Morphology of branches and calices. - A-C - external views of some branchs showing 'morphology 1'; $\times 1.5 ;$ A - specimen FCGI 3511, B - specimen USNM Psk 4. B (= Branisa 1965, pl. 48, figs 2, 3), C - specimen USNM Psk 4. 5126. • D-G - exterior views of calices; D - major calice showing 8 well exposed interseptal punctiform-like furrows; see also Fig. 23D (same specimen as C); $\times 4.5$. - E-major calice with 8 ridges and furrows (holotype, specimen FCGI 3501 , see also Fig. 13C); × 4.・F, G - calices with 12 septal ridges; $F$ - specimen FCGI 3509 (=Fig. 13B); × 4. • G-specimen FCGI 3511 (=Fig. 13A); × 4.3 .

Holotype. - Specimen FCGI 3501 (2 small branch fragments, 4 thin sections).

Etymology. - Name derived from geographic name Bolivia.
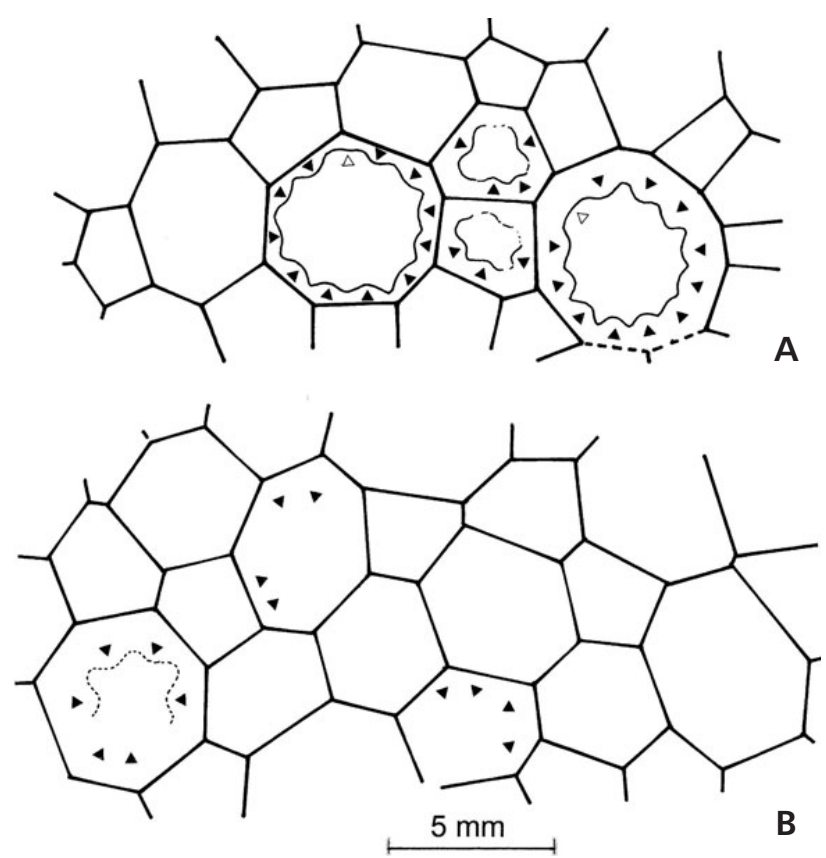

Figure 11. Parastriatopora boliviana sp. nov. Schematic outline of the corallites on the branch surface (global view) showing 'morphology 1' in A (FCGI 3509, see also Fig. 13B) and 'morphology 2' in B (FCGI 3506); see text. Black triangle for septal ridges; open triangle for 'missing' septal ridge.

Type locality. - Pisacaviña, football field ('historical' coral locality). Belén Formation, lower Member, Late Upper Emsian or Early Eifelian.

Material. - The material consists of 12 short branch fragments, 22 thin sections and 3 acetate peels. Although the number of specimens is rather limited, and their external preservation sometimes disappointing (specimens embedded in resin or corroded, occasionally even unidentifiable when only thin sections are available), some branches (or some area of the branches) are sufficiently well preserved to enable an interesting study of corallum variability, here interpreted as intra-specific. We propose in the descriptions to identify different morphologies (based on variations in calicinal aspects) and morphotypes (based on variations in internal characteristics). Specimens from the 'historical' coral locality are numbered FCGI 3500-3505, while those from the new '2005' coral locality are numbered FCGI 3506-3511. Some plaster casts and acetate peels have been housed in the Universite de Bretagne Occidentale paleontological collections, in Brest (LPB 15265-15274).

Diagnosis. - Species of Parastriatopora with branch diameter mainly between 16 and $27 \mathrm{~mm}$ (mean $20.7 \mathrm{~mm}$ ). Calices conical in shape with concave bottom and delimited by a narrow crest generally bearing granules: 8 septal ridges of various widths, with well marked interseptal furrows 
Table 1. Parastriatopora boliviana sp. nov. Quantitative (in $\mathrm{mm}$ ) and qualitative data mainly corresponding to branch structure. Db (maximum branch diameter) and Daz (axial zone diameter) measured on the same transverse section. Calice morphology type 1 (with 'major' corallites) and type 2 (without 'major' corallites), see text 'External features and calice morphology'. Septal ridges, 8 or 12, see text 'External features and calice morphology'; Periph. rim morphotype I (with tabulae) and II (without tabulae), see text 'Internal features, peripheral rim'. N: number of measurements, X: mean.

\begin{tabular}{|c|c|c|c|c|c|c|c|}
\hline & $\begin{array}{c}\text { Specimen } \\
\text { FCGI }\end{array}$ & $\begin{array}{l}\text { Calice } \\
\text { morph. }\end{array}$ & $\begin{array}{l}\text { Septal } \\
\text { ridges }\end{array}$ & $\begin{array}{l}\text { Periph. } \\
\text { rim }\end{array}$ & $\mathrm{Db}$ & Daz & $\mathrm{Daz} / \mathrm{Db}$ \\
\hline \multirow{7}{*}{ 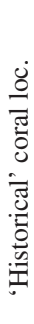 } & 3500 & & & II & 28.5 & 12.5 & 0.44 \\
\hline & 3501 & 1 & 8 & I & 16.5 & 7 & 0.42 \\
\hline & 3502 & 2 & $8(?)$ & II & 25 & 8.5 & 0.34 \\
\hline & 3503 & 2 & & II & 20.5 & 9 & 0.44 \\
\hline & 3504 & 2 & & II & 19 & 7 & 0.37 \\
\hline & 3505 & & & I & 16 & 7.5 & 0.47 \\
\hline & $\mathrm{N}$ & & & & 6 & 6 & 6 \\
\hline \multirow{9}{*}{ 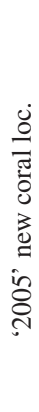 } & $X$ & & & & 20.9 & 8.6 & 0.41 \\
\hline & 3506 & 2 & $8(?)$ & I (?) & 21 & 7.5 & 0.36 \\
\hline & 3507 & 1 & $12(?)$ & II & 19.5 & 7.5 & 0.38 \\
\hline & 3508 & & & I & 27 & 12 & 0.44 \\
\hline & 3509 & 1 & 12 & I & 18 & 9 & 0.50 \\
\hline & 3510 & $1(?)$ & $12(?)$ & I (?) & 18.5 & 9 & 0.49 \\
\hline & 3511 & 1 & 12 & II (?) & 18.5 & 9.5 & 0.51 \\
\hline & $\mathrm{N}$ & & & & 6 & 6 & 6 \\
\hline & $X$ & & & & 20.4 & 9.1 & 0.45 \\
\hline \multirow{17}{*}{ 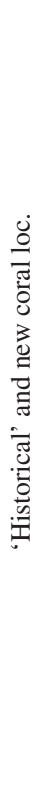 } & \multicolumn{7}{|c|}{ Morphological and structural categories } \\
\hline & $\mathrm{N}$ & 1 & & & 5 & 5 & 5 \\
\hline & $\mathrm{X}$ & & & & 18.2 & 8.4 & 0.46 \\
\hline & $\mathrm{N}$ & 2 & & & 4 & 4 & 4 \\
\hline & $\mathrm{X}$ & & & & 21.4 & 8.0 & 0.38 \\
\hline & $\mathrm{N}$ & & & & 3 & 3 & 3 \\
\hline & $\mathrm{X}$ & & 8 & & 20.8 & 7.67 & 0.37 \\
\hline & $\mathrm{N}$ & & & & 4 & 4 & 4 \\
\hline & $\mathrm{X}$ & & 12 & & 18.6 & 8.75 & 0.47 \\
\hline & $\mathrm{N}$ & & & I & 6 & 6 & 6 \\
\hline & $\mathrm{X}$ & & & & 19.5 & 8.5 & 0.45 \\
\hline & $\mathrm{N}$ & & & II & 6 & 6 & 5 \\
\hline & $\mathrm{X}$ & & & & 21.8 & 9.0 & 0.41 \\
\hline & \multicolumn{7}{|c|}{ All categories } \\
\hline & $\mathrm{N}$ & & & & 12 & 12 & 11 \\
\hline & $\mathrm{X}$ & & & & 20.7 & 8.8 & 0.43 \\
\hline & $\mathrm{R}$ & & & & $16.0-28.5$ & $7.0-12.5$ & $0.34-0.51$ \\
\hline
\end{tabular}

at the periphery of the calicinal bottom, giving rise to a bilateral symmetry formation; or up to 12 septal ridges alternating with narrow interseptal furrows with sometimes punctiform depressions on the calicinal floor, without obvious bilateral symmetry. Over half the branches show 'major' calices surrounded by a corona of 8 to 10 'minor'

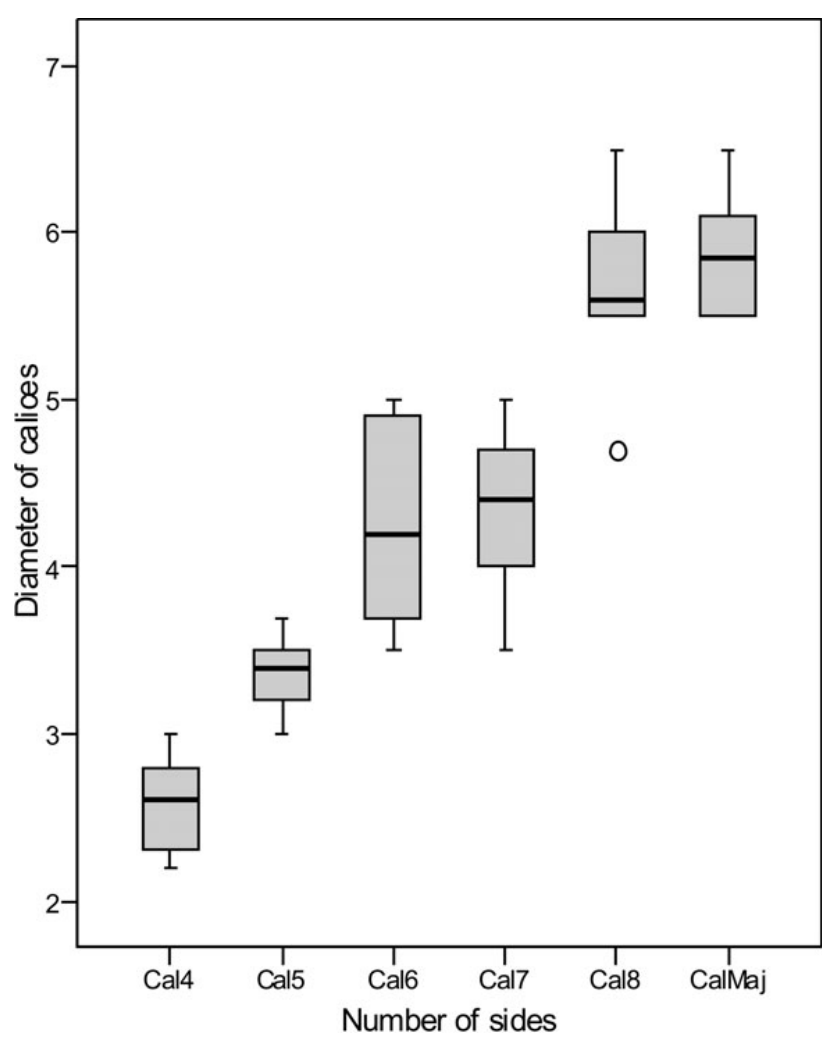

Figure 12. Parastriatopora boliviana sp. nov. Box and whisker displays showing the diameter of the calices (y-axis) measured on the external part of the branches (dimensions in $\mathrm{mm}$ ). They have been arranged into groups depending on the number of calice sides, from four-sided (Cal4) to eight or more-sided (Cal8); the final group (CalMaj) represents calices with 8 or more sides, which play a polar role in 'major' calices. See text for explanations.

ones, other branches without this setting. Adult (7-sided or more) corallites on the branch surface (= calice diameter) mainly between 5.0 and $6.0 \mathrm{~mm}$; 'major' corallites up to $6.7 \mathrm{~mm}$. Axial zone between 7-12.5 mm, rate axial zone diameter/branch diameter rate of between 0.36 and 0.51 , with an average of 0.43 . Axial zone with thin-walled corallites; angle pores, wall pores and pore plates present, spines lacking. Mean diameter of 8-11-sided corallites in the axial zone $2.80 \mathrm{~mm}$, while corallites on the periphery of the axial zone usually above $3 \mathrm{~mm}$. Lateral budding, often with a three-sided cella. Peripheral rim with generally few thickened or massive tabulae.

Description. - External features and calice morphology: The branches are cylindrical with a diameter of 16-21 $\mathrm{mm}$ in general, but up to $28.5 \mathrm{~mm}$ has been recorded (Table 1). The calices are polygonal in outline and separated by a narrow crest (Fig. 10). Two main morphological types can be distinguished:

Morphology 1: branches with some large calices/corallites surrounded by a corona of 8 to 10 small ones 
Table 2. Parastriatopora boliviana sp. nov. Diameter of corallites on the surface of branches or calices (in $\mathrm{mm}$ ) depending on the number of corallite sides; the 'major' are always 8-sided or more. Note that in the category ' $8-11$ ' the 'major' corallites are included.

\begin{tabular}{|c|c|c|c|c|c|c|}
\hline No. wall sides & 4 & 5 & 6 & 7 & $8-11$ & 'major' \\
\hline \multicolumn{7}{|c|}{ 'Historical' coral loc. } \\
\hline $\mathrm{N}$ & 3 & 8 & 15 & 14 & 5 & 3 \\
\hline $\mathrm{X}$ & 3.30 & 4.12 & 5.06 & 5.58 & 5.50 & 5.50 \\
\hline Range & $2.8-4.1$ & $3.0-4.8$ & $3.5-6.5$ & $4.2-6.4$ & $4.5-6.5$ & $5.0-6.0$ \\
\hline \multicolumn{7}{|c|}{ '2005' new coral loc. } \\
\hline $\mathrm{N}$ & 5 & 23 & 21 & 13 & 15 & 11 \\
\hline $\mathrm{X}$ & 2.54 & 3.47 & 4.21 & 4.81 & 5.90 & 5.98 \\
\hline Range & $2.2-3.0$ & $2.8-4.6$ & $3.2-5.2$ & $3.5-6.0$ & $4.7-6.7$ & $5.3-6.7$ \\
\hline \multicolumn{7}{|c|}{ Calice morphology 1} \\
\hline $\mathrm{N}$ & 6 & 21 & 12 & 13 & 17 & 14 \\
\hline X & 2.58 & 3.45 & 4.08 & 4.60 & 5.77 & 5.96 \\
\hline Range & $2.2-3.0$ & $2.8-4.6$ & $3.2-5.2$ & $3.5-5.5$ & $4.5-6.7$ & $5.0-6.7$ \\
\hline \multicolumn{7}{|c|}{ Calice morphology 2} \\
\hline $\mathrm{N}$ & 2 & 9 & 22 & 14 & 1 & \\
\hline X & 3.55 & 4.09 & 4.88 & 5.78 & 6.50 & \\
\hline Range & $3.0-4.1$ & $3.2-4.8$ & $3.7-6.0$ & $4.9-6.4$ & & \\
\hline \multicolumn{7}{|l|}{8 septal ridges } \\
\hline $\mathrm{N}$ & 2 & 8 & 12 & 9 & 5 & 3 \\
\hline$X$ & 3.45 & 3.69 & 4.52 & 5.45 & 5.50 & 5.50 \\
\hline Range & $2.8-4.1$ & $3.0-4.8$ & $3.5-6.1$ & $4.2-6.2$ & $4.5-6.5$ & $5.0-6.0$ \\
\hline \multicolumn{7}{|l|}{12 septal ridges } \\
\hline $\mathrm{N}$ & 5 & 20 & 13 & 10 & 15 & 11 \\
\hline $\mathrm{X}$ & 2.54 & 3.47 & 4.12 & 4.56 & 5.91 & 5.98 \\
\hline Range & $2.2-3.0$ & $2.5-4.6$ & $3.2-5.2$ & $3.5-5.5$ & $4.7-6.7$ & $5.3-6.7$ \\
\hline \multicolumn{7}{|c|}{ Peripheral rim morphotype I } \\
\hline $\mathrm{N}$ & 2 & 15 & 15 & 9 & 11 & 9 \\
\hline X & 2.90 & 3.53 & 4.19 & 5.06 & 5.67 & 5.88 \\
\hline Range & $2.8-3.0$ & $2.5-4.6$ & $3.5-5.2$ & $4.2-6.0$ & $4.5-6.6$ & $5.0-6.6$ \\
\hline \multicolumn{7}{|c|}{ Peripheral rim morphotype II } \\
\hline $\mathrm{N}$ & 6 & 16 & 21 & 18 & 9 & 7 \\
\hline $\mathrm{X}$ & 2.80 & 3.74 & 4.79 & 5.29 & 5.97 & 6.07 \\
\hline Range & $2.2-4.1$ & $2.6-4.8$ & $3.2-6.5$ & $3.5-6.4$ & $4.7-6.7$ & $5.5-6.7$ \\
\hline \multicolumn{7}{|l|}{ All categories } \\
\hline $\mathrm{N}$ & 8 & 31 & 36 & 27 & 20 & 16 \\
\hline X & 2.82 & 3.62 & 4.54 & 5.21 & 5.80 & 5.96 \\
\hline Range & $2.2-4.1$ & $2.5-4.8$ & $3.2-6.5$ & $3.5-6.4$ & $4.5-6.7$ & $5.0-6.7$ \\
\hline
\end{tabular}

(Fig. 11A). On the corallum surface, the 'major' corallite/calice diameter varies between 5.0 and $6.7 \mathrm{~mm}$, while that of the 'minor' corallites mainly varies between 3.5 and $4.5 \mathrm{~mm}$ (Table 2).

Morphology 2: branches with calices of various sizes, but without the particular pattern described in case 1
Table 3. Parastriatopora boliviana sp. nov. Diameter of corallites (in $\mathrm{mm}$ ) in the axial zone depending on the number of corallite sides. Per: corallites in the periphery of the area, i.e. at the boundary with the peripheral rim (the number of sides generally cannot be given but is about 8 ).

\begin{tabular}{|c|c|c|c|c|c|c|}
\hline No. wall sides & 4 & 5 & 6 & 7 & $8-11$ & Per \\
\hline \multicolumn{7}{|c|}{ 'Historical' coral loc. } \\
\hline $\mathrm{N}$ & 12 & 6 & 18 & 14 & 8 & 39 \\
\hline $\mathrm{X}$ & 1.45 & 1.70 & 2.09 & 2.32 & 2.79 & 3.00 \\
\hline Range & $1.2-1.9$ & $1.2-2.7$ & $1.7-2.8$ & $1.8-3.5$ & $2.4-4.2$ & $1.8-4.6$ \\
\hline \multicolumn{7}{|c|}{ '2005' new coral loc. } \\
\hline $\mathrm{N}$ & 9 & 10 & 8 & 9 & 8 & 29 \\
\hline $\mathrm{X}$ & 1.35 & 1.70 & 2.21 & 2.14 & 2.81 & 2.80 \\
\hline Range & $1.1-1.6$ & $1.3-2.2$ & $1.7-2.8$ & $1.6-2.5$ & $2.1-4.2$ & $1.6-4.3$ \\
\hline \multicolumn{7}{|c|}{ Calice morphology 1} \\
\hline $\mathrm{N}$ & 6 & 6 & 8 & 10 & 6 & 22 \\
\hline$X$ & 1.32 & 1.55 & 2.10 & 2.05 & 2.92 & 2.62 \\
\hline Range & $1.2-1.4$ & $1.3-1.8$ & $1.6-2.8$ & $1.6-2.5$ & $2.1-4.2$ & $1.6-4.3$ \\
\hline \multicolumn{7}{|c|}{ Calice morphology 2} \\
\hline $\mathrm{N}$ & 5 & 6 & 12 & 7 & 5 & 26 \\
\hline X & 1.58 & 1.78 & 2.14 & 2.39 & 2.64 & 2.89 \\
\hline Range & $1.3-1.8$ & $1.2-2.7$ & $1.7-2.7$ & $1.8-3.3$ & $2.4-3.2$ & $1.8-4.5$ \\
\hline \multicolumn{7}{|l|}{8 septal ridges } \\
\hline $\mathrm{N}$ & 6 & 3 & 9 & 6 & 2 & 23 \\
\hline $\mathrm{X}$ & 1.43 & 1.83 & 2.09 & 2.20 & 2.50 & 2.80 \\
\hline Range & $1.2-1.8$ & $1.7-2.1$ & $1.6-2.4$ & $1.8-2.8$ & $2.4-2.6$ & $1.8-4.5$ \\
\hline \multicolumn{7}{|l|}{12 septal ridges } \\
\hline $\mathrm{N}$ & 4 & 6 & 5 & 7 & 6 & 18 \\
\hline $\mathrm{X}$ & 1.37 & 1.55 & 2.26 & 2.09 & 2.92 & 2.65 \\
\hline Range & $1.3-1.4$ & $1.3-1.9$ & $1.7-2.8$ & $1.6-2.5$ & $2.1-4.2$ & $1.6-4.3$ \\
\hline \multicolumn{7}{|c|}{ Peripheral rim morphotype I } \\
\hline $\mathrm{N}$ & 15 & 8 & 12 & 14 & 7 & 29 \\
\hline $\mathrm{X}$ & 1.36 & 1.79 & 2.12 & 2.24 & 2.94 & 3.01 \\
\hline Range & $1.1-1.9$ & $1.3-2.2$ & $1.6-2.8$ & $1.8-2.8$ & $2.4-4.2$ & $1.7-4.3$ \\
\hline \multicolumn{7}{|c|}{ Peripheral rim morphotype II } \\
\hline $\mathrm{N}$ & 6 & 8 & 14 & 9 & 9 & 39 \\
\hline $\mathrm{X}$ & 1.53 & 1.61 & 2.13 & 2.28 & 2.69 & 2.86 \\
\hline Range & $1.2-1.8$ & $1.2-2.7$ & $1.7-2.5$ & $1.6-3.3$ & $2.1-3.2$ & $1.6-4.6$ \\
\hline \multicolumn{7}{|l|}{ All categories } \\
\hline $\mathrm{N}$ & 21 & 16 & 26 & 23 & 16 & 68 \\
\hline $\mathrm{X}$ & 1.41 & 1.70 & 2.13 & 2.25 & 2.80 & 2.92 \\
\hline Range & $1.1-1.9$ & $1.2-2.7$ & $1.6-2.8$ & $1.6-3.3$ & $2.1-4.2$ & $1.6-4.6$ \\
\hline
\end{tabular}

(Fig. 11B). The corallite/calice diameter generally varies between 3.5 and $6.5 \mathrm{~mm}$ (Table 2). It should be noted that in the specimens with calices belonging to 'morphology 2', the diameter of the 6-7-sided corallites reaches the same diameter as that of the 7-8-sided corallites found on 'morphology 1' branches, and that 8 -sided corallites are very rare (see Table 2). 


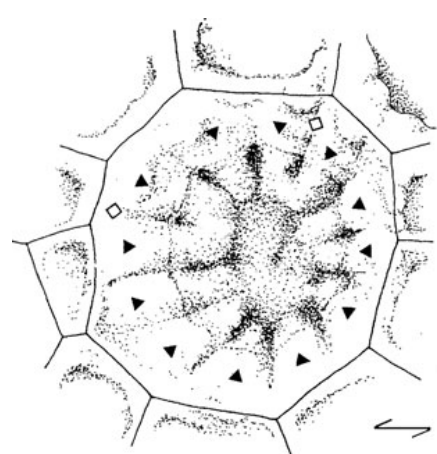

A

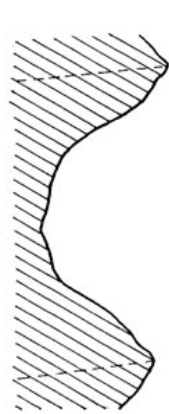

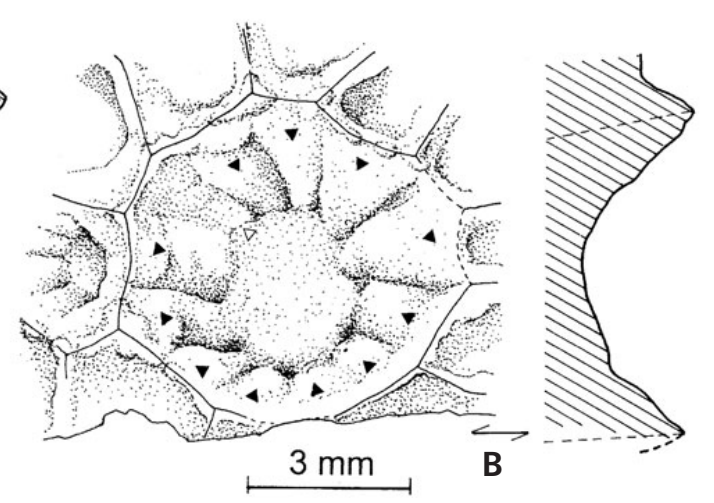

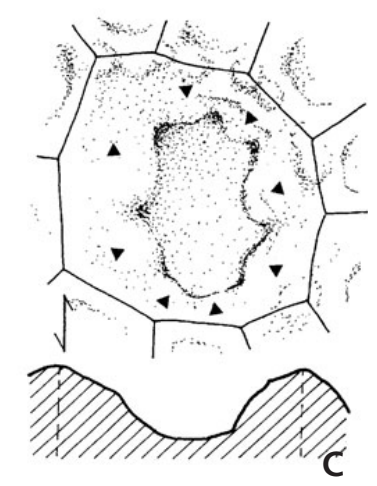

Figure 13. Parastriatopora boliviana sp. nov. Morphology and septal ridge pattern (same caption as Fig. 10), apical view and corresponding 'optical' axial section. • A - calice showing 12 septal ridges (FCGI 3511) and 2 shorter interseptal furrows (open square). $\bullet$ B - calice showing 11 septal ridges and a broad concave area probably equivalent to the 'missing' twelfth ridge (FCGI 3509). $\bullet$ C - calice with 8 well marked interseptal furrows and 8 smooth septal ridges (FCGI 3501).

In all specimens (i.e. with or without 'major' corallites), the youngest corallites are generally four-sided, while three-sided ones are very rare and sometimes not even observed. This is probably linked to a kind of lateral budding beginning with a three-sided cella, a structure which is well exposed in the axial part of the transverse sections (see below and Fig. 20B). Calice dimensions of the studied fragments are shown in Fig. 12 and Table 2.

The calices - mainly conical or with a gently curved concave bottom - are generally badly preserved and only a few calices have well exposed septal ridges. Owing to the number of septal ridges, two kinds of calices can be distinguished:

Calices with 12 septal ridges: in the few well preserved large calices studied, 12 broad and smooth septal ridges, which do not extend to the axial part and are roughly of the same width and length, alternate with narrow interseptal furrows. In their pericalicinal part, these interseptal furrows are more marked, but do not become true punctiform depressions (Figs 10F, 13A). In specimen FCGI 3511 (Figs 10G, 13A), two of the interseptal ridges are shorter than the others, giving rise to a crypto-bilateral symmetry (see also Fig. 23A and the corresponding text). In some calices of another specimen, only 11 septal ridges are developed and the site of the 'missing' one is occupied by a broad concave area (Figs 11A, 13B).

Calices with 8 septal ridges: this setting is only clearly exposed in the holotype FCGI 3501 (Figs 10E, 13C), but is found with more frequency in the specimens collected by Branisa (see below). Eight septal ridges of various widths - with broader ridges situated on the right and left sides of the corallite than those on the upper and lower part - have been well identified due to the presence of eight interseptal punctiform-like furrows strongly carved into the periphery of the calicinal bottom. The furrow/ridge pattern shows a bilateral symmetry.

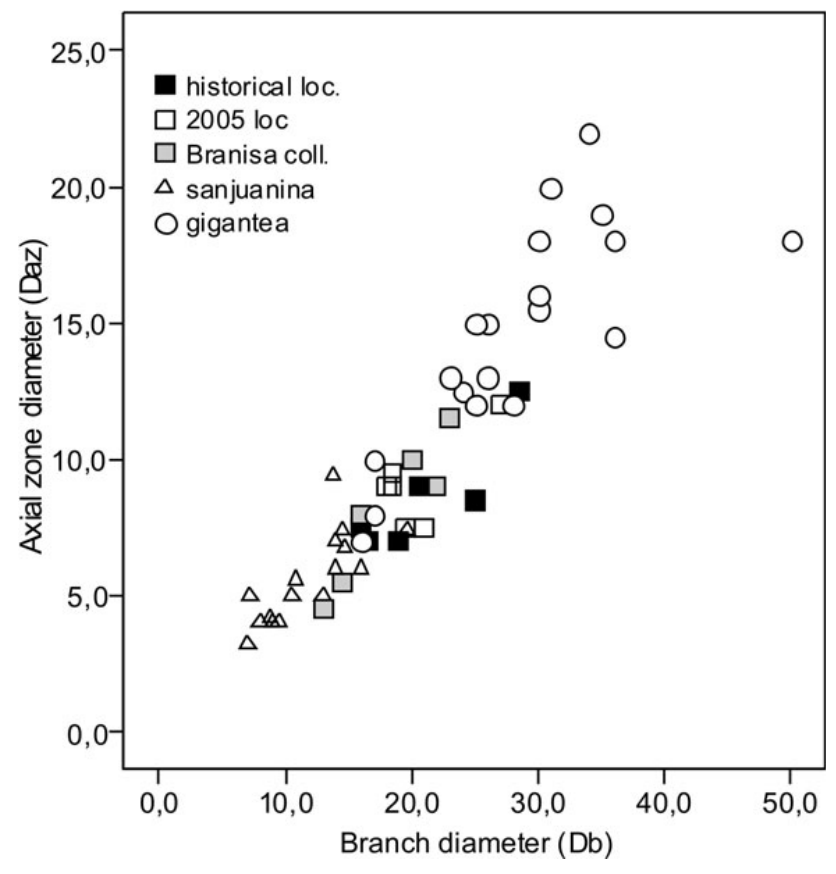

Figure 14. Parastriatopora boliviana sp. nov. Comparison of the axial zone diameter $v s$. branch diameter in the three Parastriatopora bolivia$n a$ collections (historical coral locality, new '2005' coral locality and Branisa collection), P. sanjuanina and $P$. gigantea. The chart clearly shows that these diameters are not diagnostic at species level but does reveal their increasing size from $P$. sanjuanina to $P$. gigantea (dimensions in $\mathrm{mm}$ ).

Internal features: In transverse and longitudinal sections the branches show a rather well delimited thin walled axial zone surrounded by a strongly thickened peripheral $\operatorname{rim}$ (= peripheral zone). The structure of the peripheral rim enables two groups to be distinguished: one with tabulae (morphotype I), and the other without and described as massive (morphotype II). These categories do not concur with those based on calicinal morphology. Nevertheless, branches with 'major' corallites seem to be preferentially 

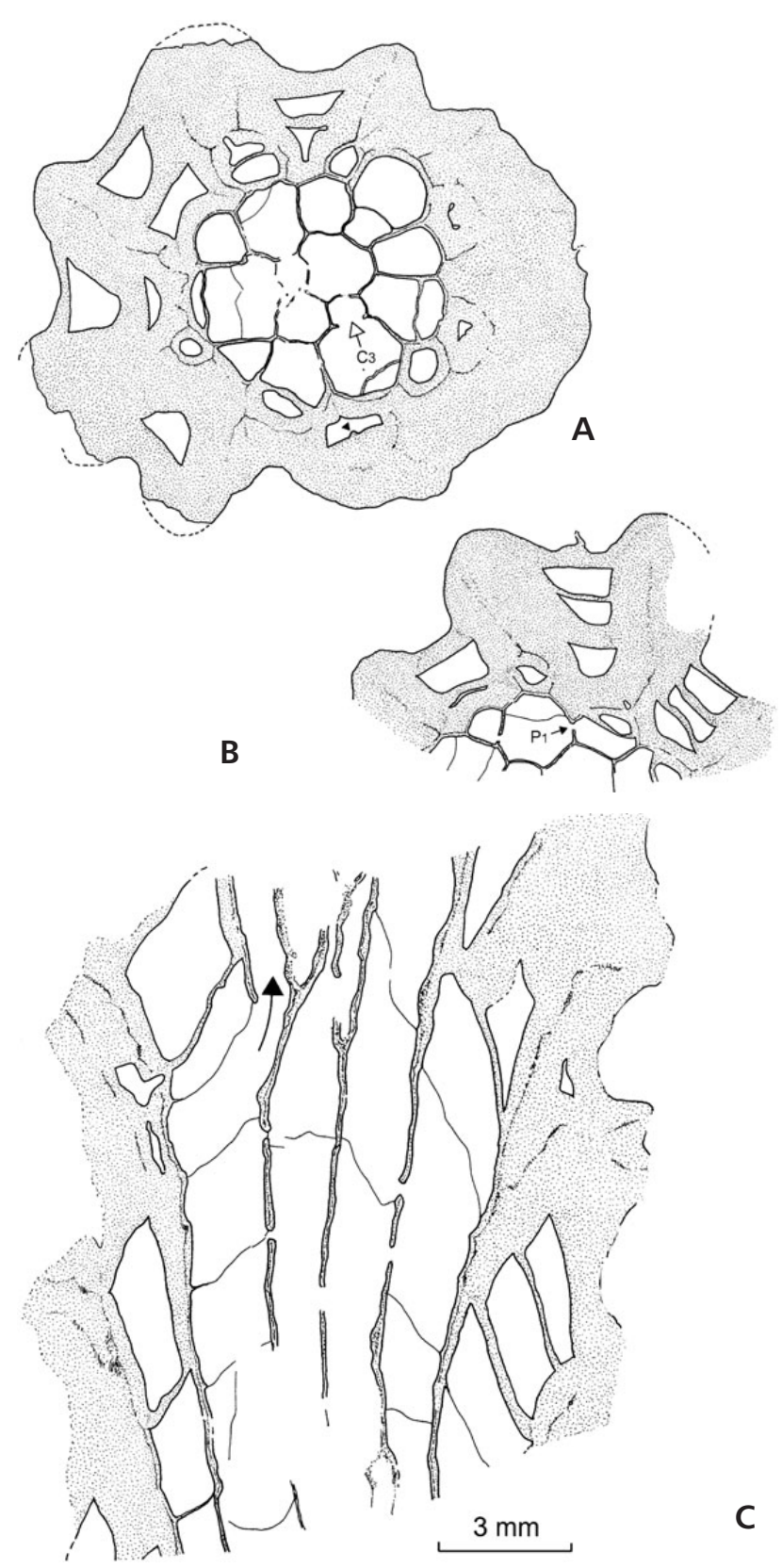

Figure 15. Parastriatopora boliviana sp. nov. Thin sections in a specimen (FCGI 3501) belonging to morphotype I. • A - transverse section, showing the closing progress of a three-sided cella (C3) and the axial knob on the proximal side of a peripheral rim tabula (black triangle) (thin section BOL II B). • B - part of another transverse section in the same specimen, showing more numerous tabulae than in the previous one and an angle pore $\left(\mathrm{P}_{1}\right)$; wall pores $\left(\mathrm{P}_{2}\right)$ are exposed outside of the figured area (thin section BOL II C). $\bullet$ C- longitudinal section, lateral budding on the dorsal side of a corallite indicated by black arrow (thin section BOL II D).

linked to a tabulated rim. For one or two specimens, such as FCGI 3506 and FCGI 3510, assignment to either morphotype I or morphotype II is uncertain. The axial zone diameter mainly varies between 7-9 $\mathrm{mm}$ (only one specimen with compact rim reaches $12.5 \mathrm{~mm}$ ) and the external diameter of the peripheral rim mainly varies between 16-21 mm (but 16.5-27 $\mathrm{mm}$ for specimens with tabulate rim, and 19-28.5 mm for specimens with compact rim). A global mean of 0.43 for the Daz/Db ratio (axial zone diameter/branch diameter) indicates a moderately developed axial zone (Table 1 and Fig. 14).

The size, structure and other characteristics of the axial zone are similar for the two forms differentiated here according to the presence/absence of peripheral zone tabulae. Thus, the following description concerns the specimens as a whole. In transverse section, the corallites are unequal in size and generally increase greatly in diameter at the outer edge of the axial zone; furthermore, they are moderately bent, thus exhibiting section(s) of tabulae (Figs 15A, 17 and 18A). Some of them show a very obvious three-sided cella in dorsal (inner) position, indicating lateral budding (Fig. 20B). The walls are thin and without spines. Mural pores belonging to the wall pore variety (Powell \& Scrutton $1978=\mathrm{P}_{2}$ sensu Plusquellec 1976) are recorded in all the sections while angle pores $\left(=\mathrm{P}_{1}\right.$ sensu Plusquellec 1976) are scarce or not observed in some specimens.

In longitudinal sections, the axial zone displays corallites following a straight line in the central area and gently curving at its edge. The tabulae are generally distant, flat and complete with sometimes very scarce tabellae. At the boundary between the axial and peripheral zone, tabulae sometimes show a slight thickening and become strongly dipping and less distantly spaced.

Data concerning cross diameter of corallites in the axial zone are given in Table 3, but require some comments. The majority of corallites is 4 to 7 sided and the average diameter is between 1.36-2.24 mm (morphotype I with tabulate rim) and 1.53-2.28 (morphotype II with compact rim). 8- or more sided corallites are scarce and their average diameters range between 2.94 (mophotype I) and $2.69 \mathrm{~mm}$ (morphotype II). Corallites situated at the edge of the axial zone are numerous (constituting about 2/3 of the measurements taken) and some $50 \%$ of them shows a diameter $\geq 3 \mathrm{~mm}$, often reaching 4.3 (morphotype I) and 4.6 (morphotype II).

In the axial zone, the average spacing of tabulae is almost identical for the two morphotypes $(2.18 \mathrm{~mm}$ in morphotype I, $1.99 \mathrm{~mm}$ in morphotype II), and in both cases all spacing is irregular with widespread measurements (Table 4).

The peripheral rim is characterized by a strong thickening of all structures and by the tendency of corallites to open perpendicular to the branch surface.

In morphotype I, the peripheral zone shows only a few thickened tabulae (Fig. 15), except in one specimen characterized by an unusual number of tabulae as well as an unusually large rim (Fig. 17). The proximal side of the tabulae is generally flat while its distal side is very often concave. In the peripheral rim of morphotype I (Table 4) 
Table 4. Parastriatopora boliviana sp. nov. Spacing of tabulae (in mm).

\begin{tabular}{lcc}
\hline & Axial zone & Periph. rim \\
\hline Peripheral rim morphotype I & & \\
\hline $\mathrm{N}$ & 38 & 43 \\
$\mathrm{X}$ & 2.18 & 0.97 \\
\hline Range & $0.7-4.2$ & $0.2-2.6$ \\
\hline Peripheral rim morphotype II & & \\
\hline $\mathrm{N}$ & 45 & \\
$\mathrm{X}$ & 1.99 \\
\hline Range & $0.5-3.8$ \\
\hline Morphotype I+II & \\
\hline $\mathrm{N}$ & 83 \\
$\mathrm{X}$ & 2.08 \\
Range & $0.5-4.2$ \\
\hline
\end{tabular}

tabulae spacing varies between 0.2 and $2.6 \mathrm{~mm}$ with a median of $0.8 \mathrm{~mm}$ and an interquartile range of between 0.5 and $1.3 \mathrm{~mm}$.

In morphotype II, the peripheral rim (at least in its median and distal part) is devoid of tabulae (Fig. 18, see also Tourneur 1992, drawing of specimen FCGI 3500). In the two morphotypes, some thickened tabulae (generally the more proximal one) show a small axial knob on their proximal side (Fig. 20A).

Microstructure: In both transverse and longitudinal sections, the wall in the axial zone shows the straight path of the median dark line flanked on either side by a rather thin stereoplasm. In the peripheral rim, the median line disappears at approximately the same time as the corallites turn sharply to lie perpendicular to the axis of the branch, and the stereoplasm is heavily thickened. The stereoplasm in the axial and peripheral zones seems to be microlamellar. Unfortunately, ultra thin sections in this material are not available and the indisputable identification of the microlamellae is a matter of conjecture. Nevertheless, the microlamellae are clearly identified in the Branisa's material (see Fig. 24).

Part conclusion. - As a consequence of the characters showing important morphological variations, as exposed above, it would appear that all the Piscaviña specimens belong to the same species. This conclusion is reached as the result, first, of a comparison of biometric data for corals from the 'historical' locality and from the new '2005' locality, and second, of the existence of different combinations observed between 1) the specimens with 'major' calices (denominated morphology 1) or without them (denominated morphology 2), 2) those with 12 or 8 septal ridges and 3) those belonging to morphotype I or II. Biometric data are similar for all the categories.

Nevertheless, comments on Table 1, which gives a summary of the main data, would seem to be necessary.

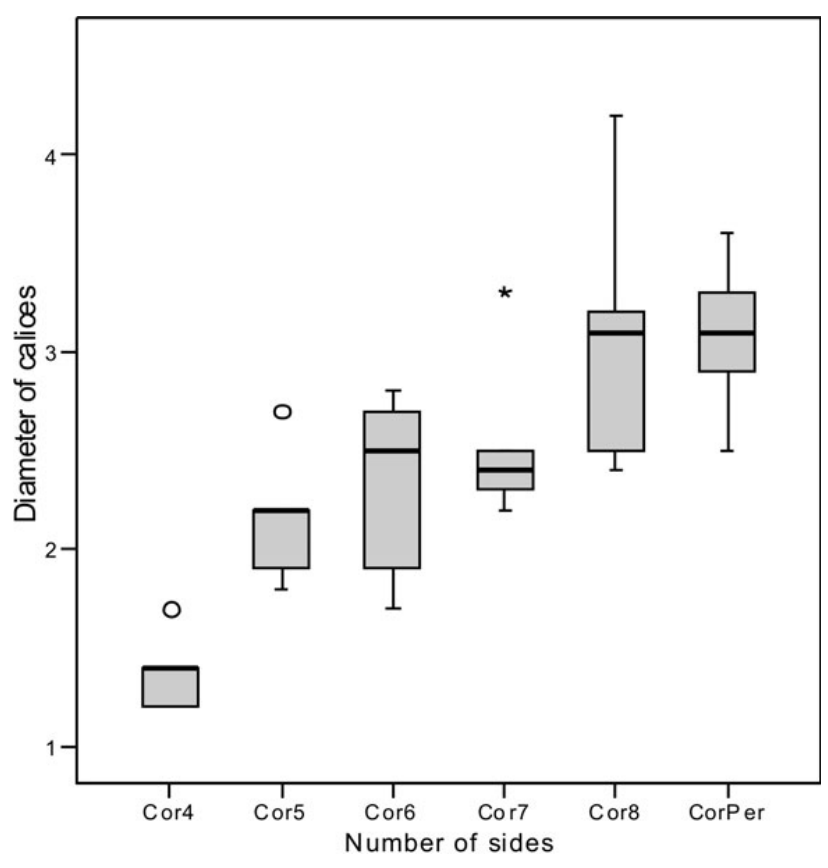

Figure 16. Parastriatopora boliviana sp. nov. Box and whisker displays showing corallite diameter (y-axis), measured on the axial zone of the branch (Cor+number) and just on the border between this zone and the peripherical rim (CorPer); dimensions in $\mathrm{mm}$. These have been arranged into groups according to the number of sides of the measured corallite (x-axis), from four (Cor4) to eight or more (Cor8). See text for explanations.

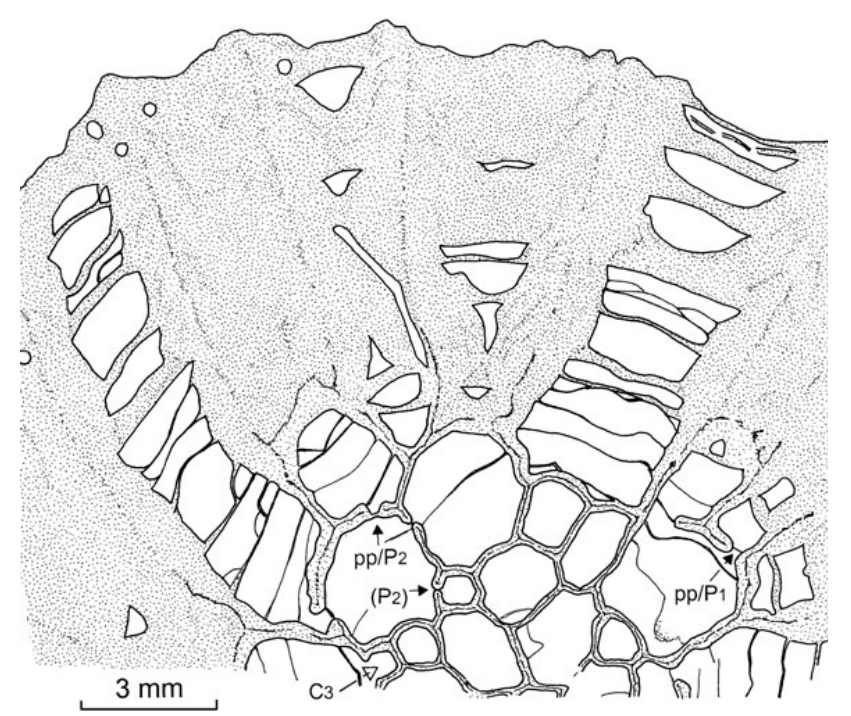

Figure 17. Parastriatopora boliviana sp. nov. Transverse thin section in one of the largest morphotype I specimens, showing unusual development of the peripheral rim tabulae, a wall pore with thickened pore plate $\left(\mathrm{pp} / \mathrm{P}_{2}\right)$, the marginal section of a mid wall pore $\left(\mathrm{P}_{2}\right)$, an angle pore with pore plate $\left(\mathrm{pp} / \mathrm{P}_{1}\right)$ and a three-sided cella $(\mathrm{C} 3)$. Specimen FCGI 3508, thin section $\mathrm{Bb} 70$.

Unfortunately, some data on calice morphology and septal ridges are occasionally missing, especially for specimens from the 'historical' coral locality, and the kind of peripheral rim described here is not always easy to assign to one 

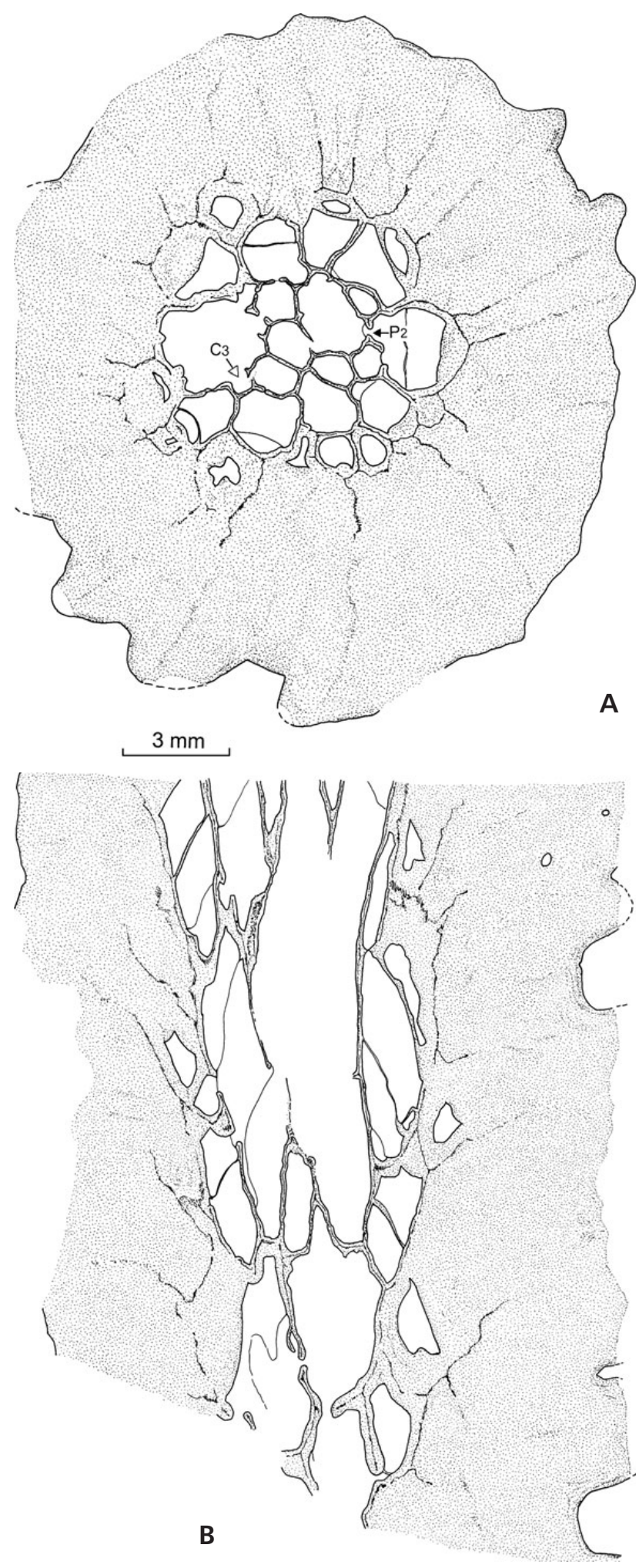

Figure 18. Parastriatopora boliviana sp. nov. Thin sections in a specimen belonging to morphotype II (specimen FCGI 3507). Calice morphology is preserved in some places by sediment remains. $-\mathrm{A}$ - transverse section, wall pore $\left(\mathrm{P}_{2}\right)$ and three-sided cella $(\mathrm{C} 3)$ on the lateral side of the parent corallite (thin section $\mathrm{Bb} 68$ ). $\bullet \mathrm{B}$ - longitudinal section (thin section $\mathrm{Bb} 67)$.
Table 5. Parastriatopora boliviana sp. nov. Branisa's material. Biometric data (in $\mathrm{mm}$ ) giving mean and range values, respectively, for each measurement.

\begin{tabular}{|c|c|c|c|c|c|}
\hline \multicolumn{6}{|c|}{ Diameter of branches } \\
\hline \multicolumn{2}{|c|}{$\mathrm{Db}$} & \multicolumn{2}{|c|}{ Daz } & \multicolumn{2}{|c|}{$\mathrm{Daz} / \mathrm{Db}$} \\
\hline \multicolumn{2}{|c|}{18.1} & \multicolumn{2}{|c|}{8} & \multicolumn{2}{|c|}{0.44} \\
\hline \multicolumn{2}{|c|}{$13-23$} & \multicolumn{2}{|c|}{$4.5-11.5$} & \multicolumn{2}{|c|}{$0.38-0.5$} \\
\hline \multicolumn{6}{|c|}{ Diameter of calices } \\
\hline 4 & 5 & 6 & 7 & $8-11$ & 'major' \\
\hline 3.13 & 3.79 & 4.40 & 5.00 & 5.94 & 6.17 \\
\hline $1.5-4.1$ & $2.6-5.2$ & $3.2-6.5$ & $3.6-6.8$ & $4.6-7.3$ & $5.2-7.3$ \\
\hline \multicolumn{6}{|c|}{ Diameter of corallites axial zone } \\
\hline 4 & 5 & 6 & 7 & $8-11$ & $\mathrm{P}$ \\
\hline 1.16 & 1.72 & 2.20 & 2.06 & 2.60 & 2.63 \\
\hline $0.9-1.4$ & $1.3-2.1$ & & $1.5-2.5$ & $2.2-3.4$ & $1.3-4.3$ \\
\hline \multicolumn{6}{|c|}{ Spacing of tabulae } \\
\hline \multicolumn{3}{|c|}{ Axial zone } & \multicolumn{3}{|c|}{ Peripheral zone } \\
\hline \multicolumn{3}{|c|}{2.04} & \multicolumn{3}{|c|}{1.40} \\
\hline \multicolumn{3}{|c|}{$0.6-4.7$} & \multicolumn{3}{|c|}{$0.3-3.0$} \\
\hline
\end{tabular}

or other of the two morphotypes defined. Moreover, the 12-ridge setting has not been observed in specimens from the 'historical' coral locality, the combinations 1-8-II, 2-12-I and 2-12-II have not been identified, and the combinations 1-12-II, 2-8-I and 2-8-II are uncertain. In addition, the branches collected by Branisa, probably at the 'historical' coral locality (see below), are mainly of the 1-8-I type and calices with 12 septal ridges of roughly the same width and length are not recorded (the specimen with 12 poorly prominent septal ridges - see description below - is in fact closer to pattern 8).

Discussion. - The occurrence of the genus Parastriatopora is known from several early and Middle Devonian localities in South America. Until now, two species have been described: $P$. sanjuanina Fernández-Martínez, Plusquellec \& Tourneur, 1999, from the lower part of the Talacasto Formation, Late Lochkovian of the Precordillera in Argentina, and P. gigantea (Knod, 1908), from the lower Member of the Belén Formation, considered as Pragian-Emsian in the type area of the species (Tourneur et al. 2000, p. 711). In addition, undescribed specimens or species have been recorded in Bolivia, especially from a locality situated $9 \mathrm{~km} \mathrm{~S}$ of Comarapa (Prov. de Santa Cruz), tentatively assigned to the Icla Formation, Pragian-Eifelian (Coll. M. Suárez-Riglos), and from a section of Cerro Alma Suchuma, SW of Copacabana de Andamarca (Western Cordillera), Huamampampa Formation, Bed 91-19-11 (Blieck et al. 1996), Eifelian/Givetian boundary or more probably early Givetian. This latter is probably the latest occurrence of Parastriatopora to be dated with reasonable precision. 


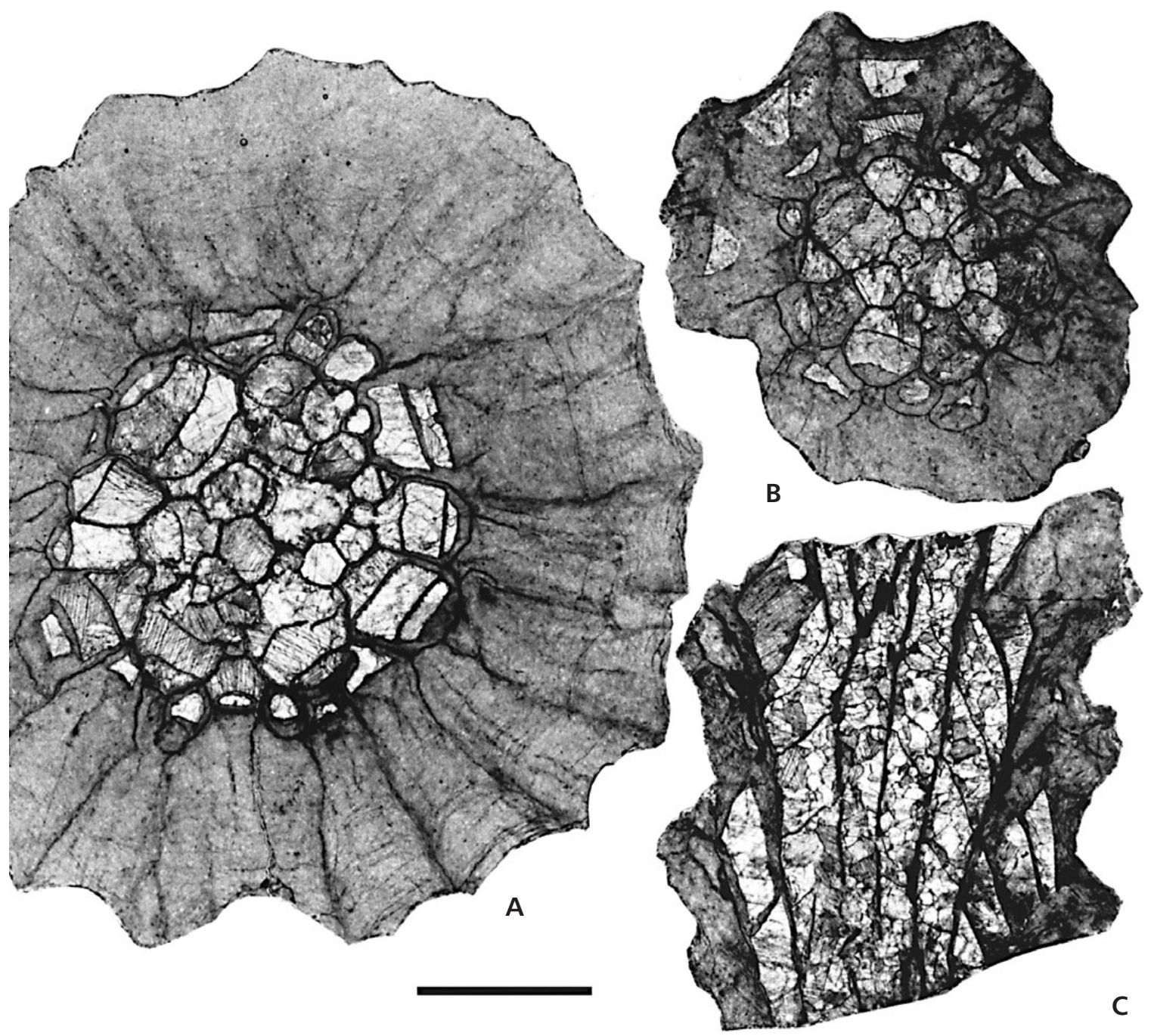

Figure 19. Parastriatopora boliviana sp. nov. • A- transverse section of a branch with compact peripheral rim, i.e. 'morphotype II' (FCGI 3500 , thin section BOL I A). $・$ B, C - transverse and axial sections (= Fig. 15) showing a peripheral rim with tabulae, i.e. 'morphotype I' (holotype, FCGI 3501 , thin sections BOL II B and BOL II D). Scale bar $5 \mathrm{~mm}$.

The Pisacaviña material differs from $P$. sanjuanina both quantitatively, with larger dimensions for all parameters, and qualitatively, due to its calicinal morphology (in some specimens, lack of punctiform depressions at the margin of the calicinal floor, these being constant and well marked in P. sanjuanina), and the structural variability of the peripheral rim (specimen with tabulae not recorded for P. sanjuanina).

$P$. boliviana sp. nov. is close to $P$. gigantea except in the following characteristics: the calicinal morphology is different, and the Pisacaviña specimens do not show a convex calicinal bottom. At the same time, there is a strong tendency to form 'major' and 'minor' calices - a feature not seen in $P$. gigantea. The number of septal structures is different, with $P$. gigantea frequently presenting six narrow interseptal furrows, and furthermore, bilateral calice symmetry has not been recorded in this species.
The Daz/Db ratio is smaller in $P$. boliviana sp. nov. (0.42) than in $P$. gigantea $(0.52)$, and mature corallite calice diameters are generally larger. Taking into account the box chart of P. gigantea (Tourneur et al. 2000, fig. 8), it would appear that the median value of calice diameters for $P$. boliviana sp. nov. (measured according to the number of sides) is systematically in the very 'upper' part of the interquartile range of $P$. gigantea. With the exception of 4-sided corallites, the median value for axial zone corallite diameters is in the 'upper' part, or beyond, the interquartil range of gigantea.

In an abstract, Tourneur (1992) assigned the colonies collected by Janvier \& Gagnier at Pisacaviña to $P$. gigantea and illustrated a transverse section. This was prior to the $P$. gigantea type material revision (Tourneur et al. 2000), and the specimen figured by Tourneur (FCGI 3500) is a branch of $P$. boliviana sp. nov. belonging to morphotype II as shown here. 


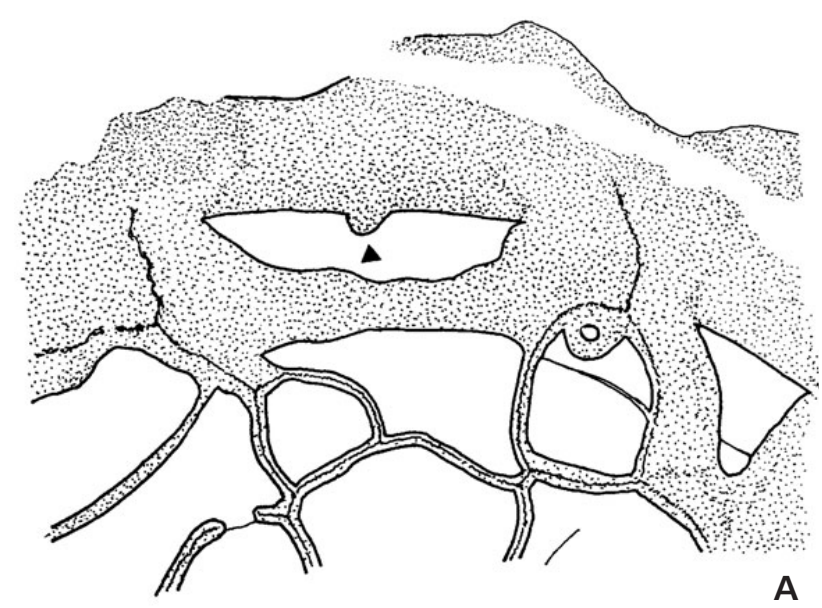

A

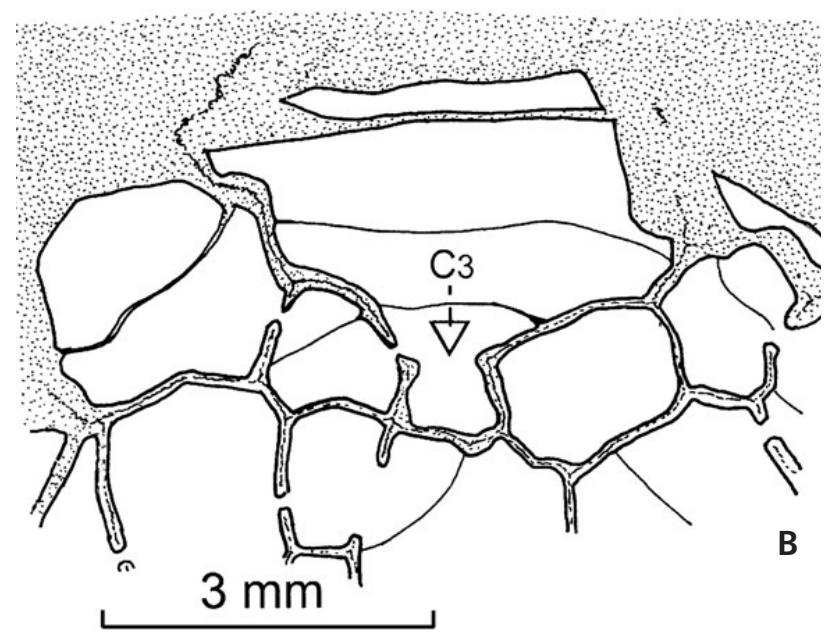

Figure 20. Parastriatopora boliviana sp. nov. • A - transverse section showing a small axial knob (black triangle) on the proximal side of a tabula in the peripheral rim (morphotype I), FCGI 3505, thin section GAG 2. • B - transverse section showing a well exposed three-sided cella (C3) in a large corallite in the peripheral part of the axial zone, FCGI 3510, acetate peel 31/03/08.

In another paper dealing with Devonian fossil localities in Bolivia (Blieck et al. 1996), P. gigantea (det. Y. Plusquellec) is recorded from the Huamampampa Formation, in a section located to the SW of Copacabana de Andamarca. This was also prior to the revision of $P$. gigantea. Although the corallum structure is badly preserved (dolomitized), two items of data are of special interest: first, the rather large size of some of the branches (up to $30 \mathrm{~mm}$ ) and, in a $\varnothing \mathrm{branch} / \varnothing$ axial zone diagram, their location within the area of $P$. gigantea, and second, a calice morphology which differs from both $P$. boliviana sp. nov. and $P$. gigantea. Thus, it would seem more appropriate to accept the Copacabana de Andamarca material as belonging to Parastriatopora sp., and consequently not to use it for correlations with Pisacaviña (Blieck et al. 1996, p. 305).

The Parastriatopora specimens from Pisacaviña have a Daz/Db ratio very similar to that of $P$. floralis-annulatus
(Le Maître 1952) if the specimens from the type area [Saoura/Ougarta in Algeria, Dkhissa Formation, lower Member, Late Lochkovian (Boumendjel et al. 1997)], and from the Armorican Massif in France [lower part of the Saint-Céneré Formation, Late Lochkovian [Plusquellec in Lardeux 1976)] are considered. The data given herein in Table 5 enables the Daz/Db ratio to be calculated; using only the mature specimens (i.e. those with a diameter of $10 \mathrm{~mm}$ or more), the ratio is 0.43 . The coralla diameter is generally smaller in $P$. floralis-annulatus (mainly 10-20 mm, although with some branches this can reach 28-30 $\mathrm{mm}$, and even $40 \mathrm{~mm}$ for the largest one), and the tabulae are both more numerous and more frequent in the peripheral rim. In addition, $P$. floralis-annulatus calices clearly differ from those of the Pisacaviña species, and present the following features: shallow calices with a broad, more or less flat calicinal bottom, rather strongly dipping calicinal wall with 12 very weakly developed septal ridges, but with pericalicinal punctiform depressions (see Le Maître 1952, pl. 6, fig. 3, here called forma annulatus), or with calicinal wall less dipping $\left(40^{\circ}\right), 12$ well developed septal ridges, punctiform depressions present and calicinal bottom somewhat less broad and convex (see Le Maître 1952, pl. 5, fig. 8, here called forma floralis). A recent, unpublished, revision (Y.P.) of the material collected in Ougarta shows that: 1) formae floralis and annulatus are recorded in four of the five localities studied by Boumendjel et al. (1997); 2) at one of these localities, only annulatus was collected; 3) floralis is less common than annulatus; and 4) the peripheral rim of floralis and annulatus shows tabulae (such as morphotype I of P. boliviana sp. nov.) or is devoid of them (morphotype II).

In both cases the presence of 'major' corallites with a corona of smaller ones is extremely rare and atypical. Le Maître (1952, p. 67) indicates the occurrence of mural pores in the calices of $P$. annulatus. This is not true for the species described here, as the specimens concerned are from the Late Emsian and belong to $P$. sp. nov.? cf. cantabrica Tourneur \& Fernández-Martínez, 1991, where this unusual feature is well exposed (see also Tourneur \& Fernández-Martínez 1991, pp. 12-14 and fig. 14).

A comparison can be made between the Pisacaviña specimens and a set of three closely related species known in the Emsian of Northern Gondwana:

P. cantabrica Tourneur \& Fernández-Martínez, 1991; Cantabrian Mountains, Spain, Abadia Formation, Requejada Member, Early Emsian, gronbergi Zone.

P. crassimura (Termier \& Termier, 1950) = pachyspinosa (Termier \& Termier, 1950), the species is called Favosites crassimurus (p. 75), and Favosites pachyspinosa in the legend of pl. 27 (the thick septal ridges bear some spines); very probably from the Lower Amerboh Formation, Hamar Laghdad, Tafilalt, Morocco, Early Late Emsian (Tourneur \& Fernández-Martínez 1991, pp. 14-16; 

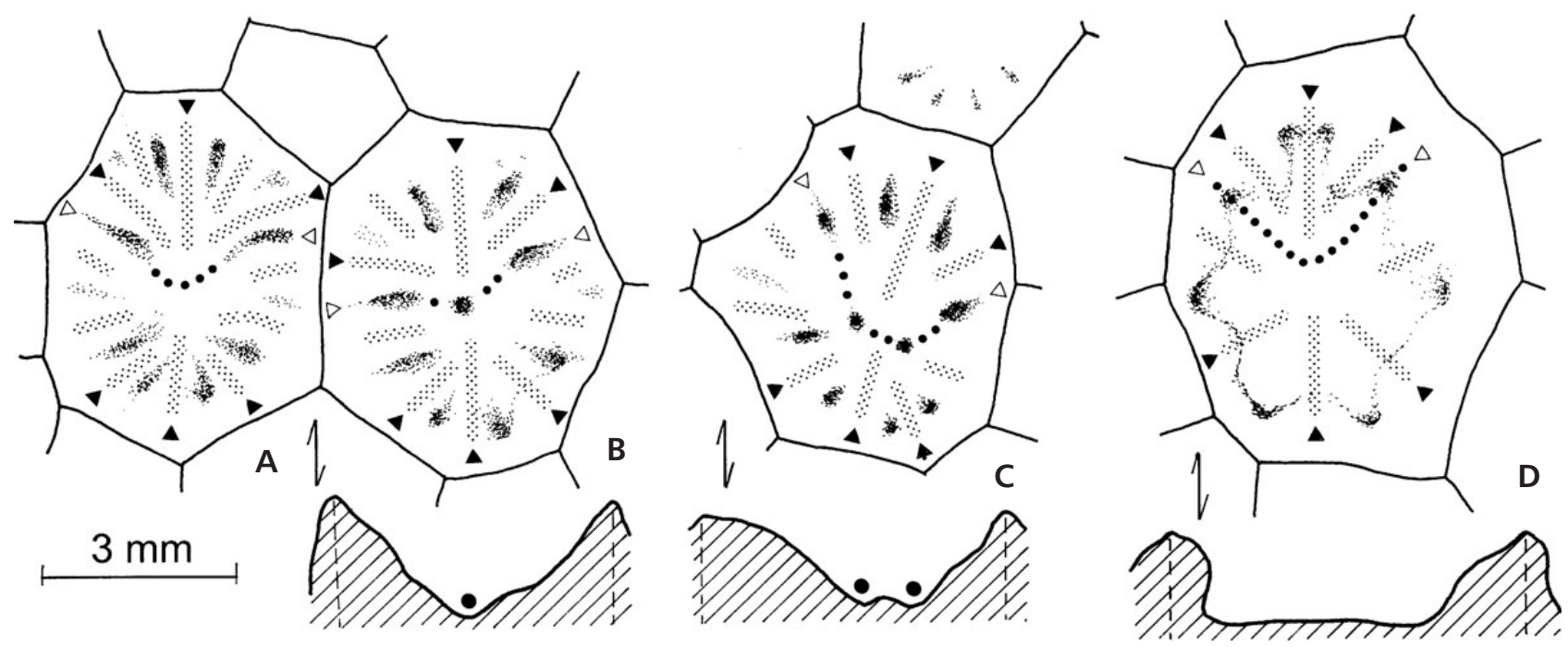

Figure 21. Parastriatopora boliviana sp. nov. Drawings of the calicinal morphology and its interpretation, same caption and orientation as Fig. 21; the path of the alar fossula is complemented by a bold dotted line. $\bullet \mathrm{A}-\mathrm{C}-$ specimen USNM Psk 4; B - calices with 8 well marked and 1 to 4 weak interseptal furrows; see Fig. 11B, calice A and B top left and middle, calice C mid-centre. $\bullet$ D - specimen USNM Psk 4. 5126, calice with only 8 interseptal furrows (usual in P. boliviana) but with an unusually flat bottom (see Fig. 11D).

Brachert et al. 1992, fig. 23) and undescribed material collected by Y.P. (1995) in the cover of Kess-Kess 3 sensu Brachert et al. 1992 (the only figured specimen by Termier $\&$ Termier, probably held in Termier's former collection in Paris, cannot presently be traced).

P. sp. nov.? cf. cantabrica Tourneur \& FernándezMartínez, 1991; Coral bed of Lower Chefar el Ahmar Formation in the Ougarta area, Algeria, Late Emsian, undescribed material which is close to the true P. cantabrica but with stronger septal ridges (without spines) and sometimes an interseptal ridge extending onto the calicinal floor.

These three species share the following features: calice diameter of between 3.7-4.5 mm, absence of 'major' calices, more or less flat calicinal bottom, presence of mural pores in the calicinal walls and peripheral rim generally showing numerous tabulae. Thus, the Bolivian specimens differ from the cantabrica-crassimura group in the development of 'major' calices, the conical shape of their calices, the lack of mural pores in their calices, the larger size of the calices, the much more compact peripheral rim and the smaller Daz/Db ratio (mainly between $0.53-0.68$ in P. cantabrica for example).

The Pisacaviña specimens can be distinguished from some other Devonian species outside of Gondwana with a well developped peripheral rim by their larger branch and corallite dimensions. For example, P. marginata Dubatolov, 1969 (Early Devonian), whose sections are similar to those of our material (morphotype II), has a branch diameter not exceeding $13 \mathrm{~mm}$ and the diameter of the axial zone corallites is between 0.6 and $1.8 \mathrm{~mm}$. In contrast, some large branches exhibit a not very thickened peripheral rim e.g. P. grandis Dubatolov, 1969 (Early Devonian) and P. grandissima houershanensis Yeh \& Chow in Yeh \& Zhou, 1975 (Early Middle Devonian). In addition, the axial zone in some species forms majority of the corallum and the Daz/Db ratio can reach 0.79 , as is the case for P. rzonsnickajae Dubatolov, 1959 (Lochkovian). Finally, it should be noted that for nearly all the species described outside of Gondwana, calice morphology is not known (no description and/or no detailed figure) and furthermore, Russian or Chinese material is not available for comparative study. This situation is unfortunate as in our opinion calice morphology - even if it shows intraspecific variations - provides interesting diagnostic characteristics.

Conclusion concerning the specific assignment. - The Parastriatopora specimens from Pisacaviña belong to a new species: $P$. boliviana sp. nov. The only significant difference between branches collected at the two levels concerns the morphology and number of septal ridges: in the 'historical' coral locality (upper level) only the 8 pattern is recorded (see below for complementary data obtained from Branisa's specimens), while in the lower level (new '2005' coral loc.), only the presence of the 12 pattern has been clearly identified. Nevertheless, this criterion is not considered important for specific distinction and compared with the Parastriatopora from Ougarta, we can provisionally distinguish two forms at Pisacaviña: the 8 and the 12 .

Additional data upon the material collected by Branisa. A set of six specimens (USNM Psk 4. A, Psk 4. B (= Branisa 1965, pl. 48, figs 2, 3), Psk. E, Psk 4. 2921, Psk 4. 5126 and Psk 4. 7922) from the Branisa's collection are assigned 


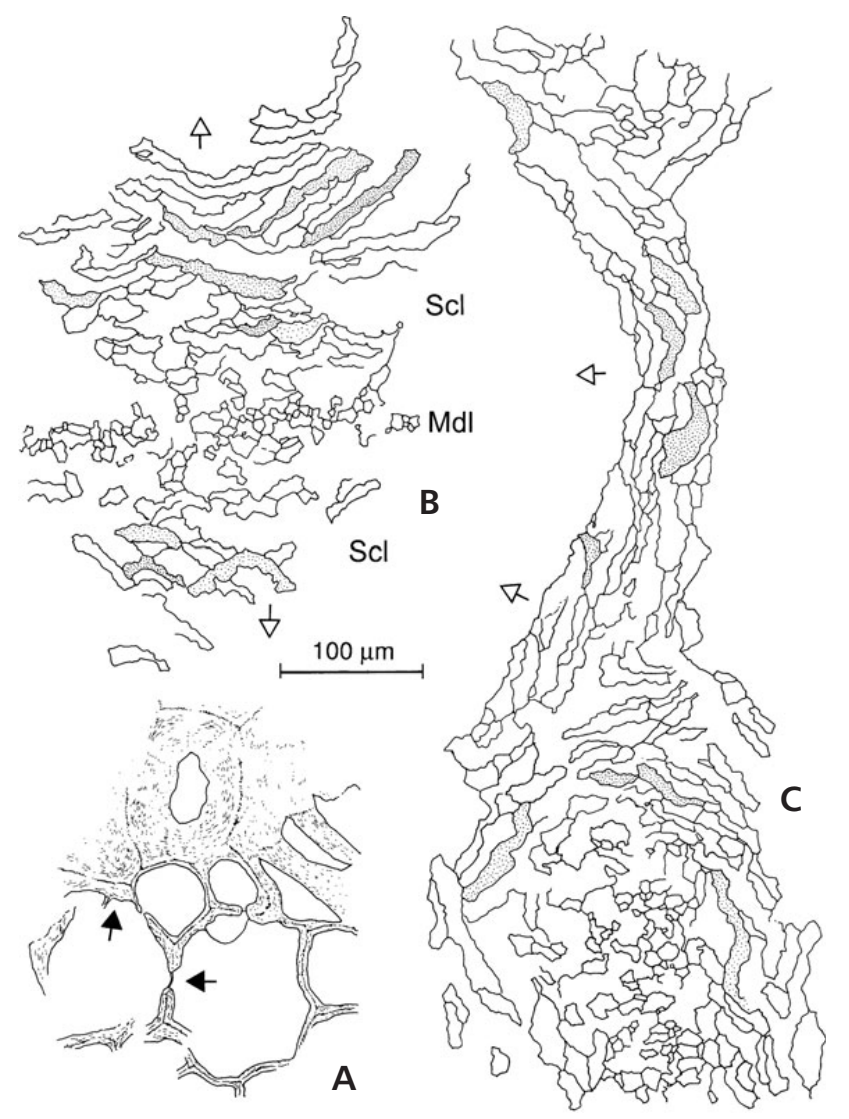

Figure 22. Parastriatopora boliviana sp. nov. Microstructure of specimen USNM Psk 4. 5126. - A - transverse ultra thin sections in the branch near the boundary between axial zone and peripheral rim, note the development of thickened tabulae in the peripheral rim; location (black arrows) of the detailed drawings $\mathrm{B}$ and $\mathrm{C}$. - B - microstructure of the wall, granular middle 'dark line' (Mdl) with microlamellar sclerenchyma on both sides (Scl) and a microlamellae-lamellae succession on top of figure; open arrows indicate the direction of skeleton accretion. $\cdot \mathrm{C}-$ microstructure of a pore plate closing a mural pore $\mathrm{P}_{2}$.

here to $P$. boliviana sp. nov. and thus could have been collected in Pisacaviña (in the 'historical' coral locality) as reported by Branisa. The morphological variations as regards the calices (with a strong trend among all the specimens to belong to 'morphology 1'), the structure of the peripheral rim (one of six specimens with compact rim) and the measurements, are all consistent with the characteristics of the specimens collected by Janvier \& Gagnier then Janvier \& Racheboeuf. The material will not be described again in detail here, but three interesting items of data, the first related to calice morphology, the second to septal ridges, and the third to microstructure, are examined, and complete the previous description.

One specimen (Psk 4. A) shows a very large area with calices of more or less equal size, especially on one side of the branch, thus belonging to 'morphology 2', while on the other side there is an area with 'major' corallites, therefore belonging to 'morphology 1'. This case indicates that the specimen belongs both to morphology 1 and 2 and that if the branch fragment had been smaller, it could have been assigned to either one or the other.

The septal ridges are better exposed than in the material used to describe the new species. Calices with 12 identically developed septal ridges have not been positively identified; calices with 8 septal furrows and 8 septal ridges of irregular width, exhibiting moreover a more or less perfect bilateral symmetry, are frequent.

One specimen presents an interesting feature halfway between the two patterns previously described and shares some characteristics with the calices of $P$. sp. $1 \mathrm{cf}$. $P$. boliviana sp. nov. Its calices are conical and polygonal in outline, with the larger ones generally 7 - to 11-sided and separated by a narrow crest. The septal riges are poorly prominent but eight of the interseptal furrows are clearly emphasized by pericalicinal punctiform/pyriform depressions, or sometimes by the occurrence of an axial or subaxial depression (Fig. 21B), or by a pair of depressions (Fig. 21C). In addition, the most interesting feature of this specimen is that some weak and more peripheral depressions are present. They are generally arranged two at a time (Fig. 21A) or sometimes 'independently' (Fig. 21C). When the calice bears two pairs of these depressions, the total number of septal ridges reaches 12 and an inconspicuous bilateral symmetry is observed. In this case, the Rugosa-like pattern of the ridges described in $P$. sp. 1 cf. $P$. boliviana sp. nov. (see below p. 25) can be observed (compare Fig. 21A with 23A). Furthermore, the axial depression(s) can be interpreted as the proximal part of the alar furrows (Fig. 21B, C), as they are clearly not ordinary holes.

The main biometric data are given in Table 5. The comparison with the material of Janvier \& Gagnier and Janvier \& Racheboeuf shows no significant differences.

Additional data on the microstructure are drawn from ultra thin sections made in the wall of specimen USNM Psk 4. 5126 (Fig. 22). The median 'dark' line is made up of numerous granules of about $8-15 \mu \mathrm{m}$ in diameter. This structure is flanked on both sides by a microlamellar stereoplasm. The length of these microlamellae mainly varies between $35-50 \mu \mathrm{m}$, with a thickness of about $10 \mu \mathrm{m}$, and they are between 15-20 $\mu \mathrm{m}$ high, or even $30 \mu \mathrm{m}$ when strongly geniculate. In the inner part of the peripheral rim, the microlamellae are sometimes covered by lamellae reaching up to $110 \mu \mathrm{m}$. This is a good example of the microlamellae-lamellae succession already described in Syringopora (Lafuste et al. 1992). Among mural pores, some are obstructed by pore plates and new data can be provided for this structure. The pore plate comprises a thin layer of microlamellae with a unidirectional orientation (Fig. 22C). This indicates that the structure is secreted by one of the two adjacent polyps. Thus, the pore plate is similar to a tabula and clearly cannot be a filmy wall. 

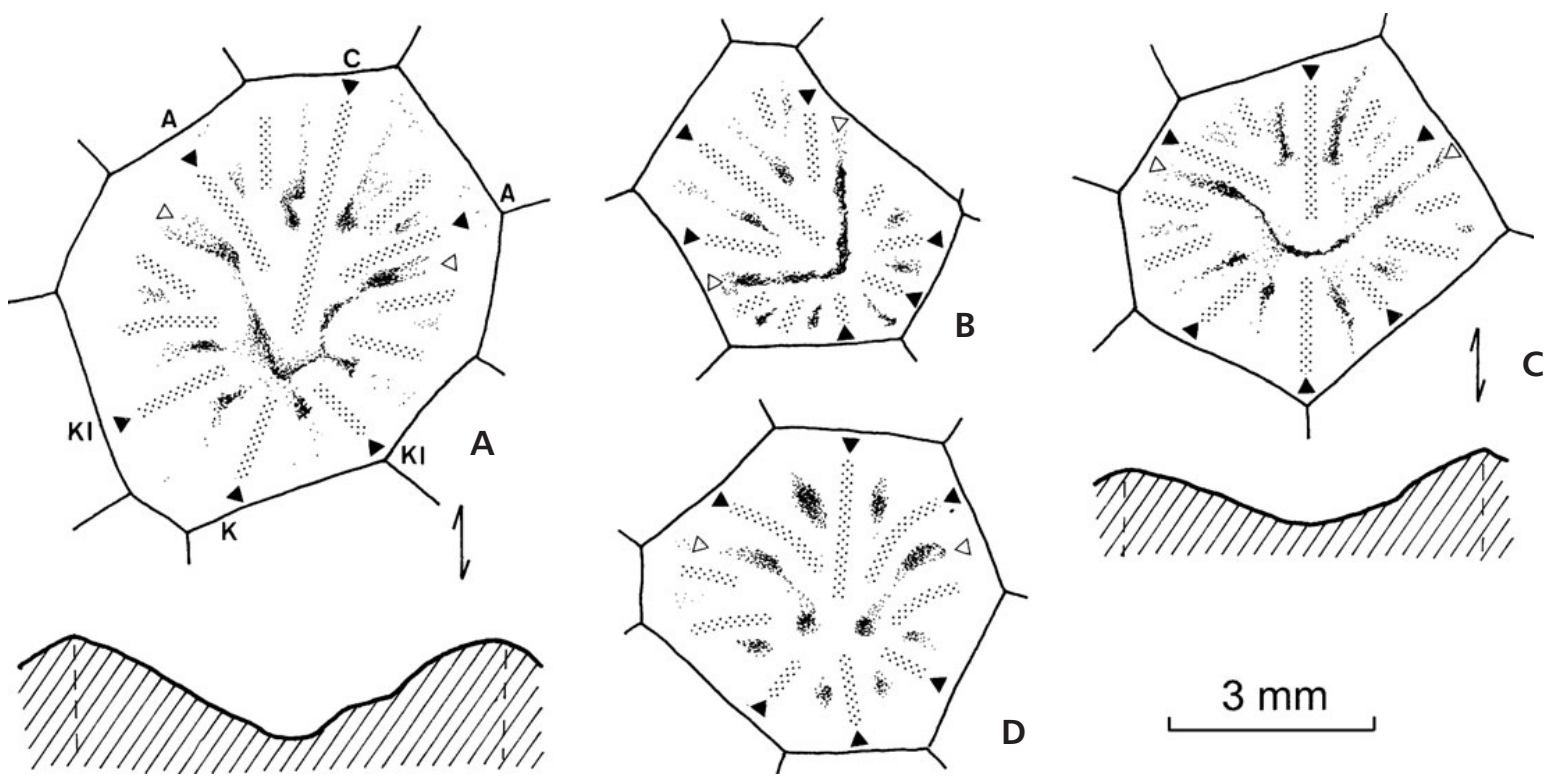

Figure 23. Parastriatopora sp. 1 cf. P. boliviana. Drawings of some calices showing the Rugosa-like pattern of the interseptal furrows and ridges (axis of the branch always 'N-S' and direction of growth from $\mathrm{S}$ to N) and a calice section. Open triangles: alar fossulae; dotted strips; septal ridge axis; black triangles: protoseptal ridges, C: cardinal ridge, K: counter ridge, Kl: counter-lateral ridges, A: alar ridges. Specimen USNM Psk 4. 2002 (= Branisa 1965, pl. 48, fig. 6; see also Fig. 22).

\section{Parastriatopora sp. 1 cf. P. boliviana sp. nov.} Figures 23, 24

1965 Striatopora cf. S. missouriensis Meek \& Worthen, 1868. - Branisa, pl. 48, fig. 6.

One of the specimens figured by Branisa (1965, pl. 48, fig. 6) is questionably assigned to P. boliviana sp. nov. owing to the unusual thickness of the peripheral rim (Daz/Db 0.33), the rather large size of the corallites on the branch surface (up to $7.7 \mathrm{~mm}$ for the 'major' one), and the particular morphology of the calices. The peripheral rim is entirely devoid of tabulae ( $c f$. morphotype II) and the calice pattern belongs to the so-called morphology 1 , especially on the tip of the branch where the 'major' corallites of about 7-7.5 $\mathrm{mm}$ are surrounded by a corona of 'minor' ones of $4-5 \mathrm{~mm}$. The calices exhibit a very interesting septal ridge feature, and consequently they are described here in detail.

The transverse sections of the calices are shallow and poorly conical with narrow, rather smooth edges (Figs 23, 24). The septal ridges are poorly prominent but, on the other hand, eight of the interseptal furrows are well marked and mainly indicated by elongated, narrow depressions situated midway along their overall length. Generally, a maximum of four (i.e. two pairs) hardly 'carved', additional interseptal furrows are situated in a more peripheral position and their location with regard to the eight main furrows does not appear to be random.
The plan of interseptal furrow insertion shows an obvious bilateral symmetry (Fig. 23), as does that of the ridges. Generally, two opposite interseptal furrows are longer than

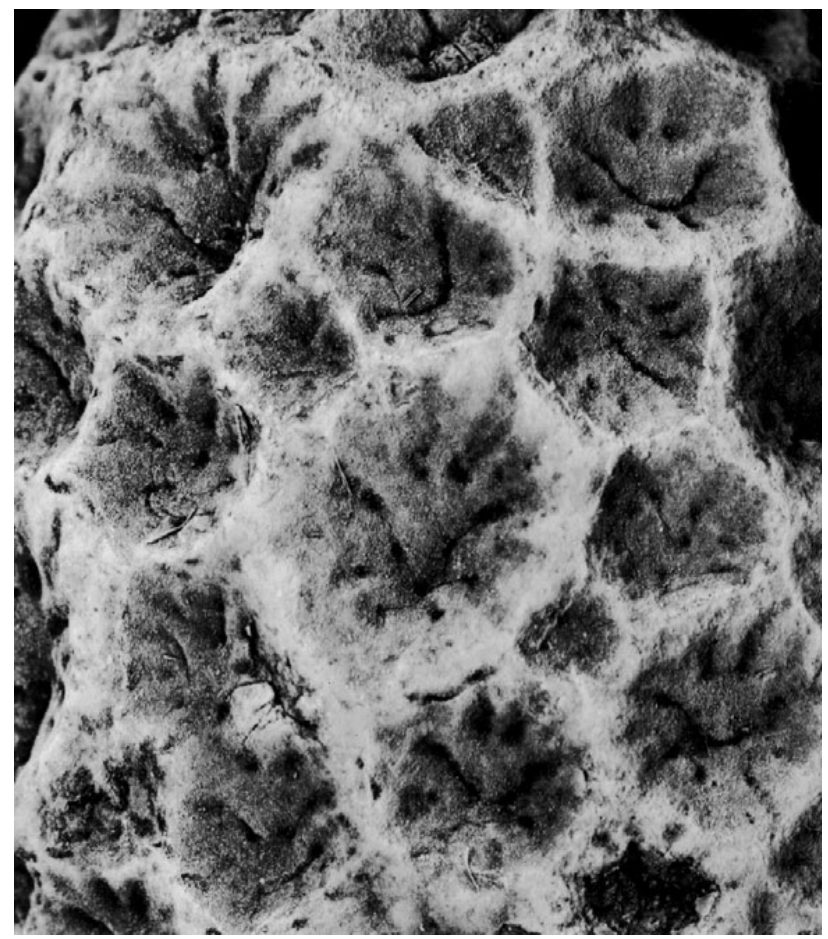

Figure 24. Parastriatopora sp. 1 cf. P. boliviana. Exterior view of calices with well exposed interseptal furrows and radiobilateral symmetry; see text and Fig. 21 (specimen USNM Psk 4. 2002), $\times 5$. 
the others and are frequently connected at the corallite axis. With regard to the corallum direction of growth, the interseptal furrows on the lower side are more numerous (4-6) than on the opposite side (2-4).

Figure 23 shows the morphology of some calices and their interpretation. The plan of insertion of the ridges shows a Rugosa-like pattern. The connected interseptal furrows are interpreted as two alar fossulae. The six protoseptal ridges are flanked by eight stronger interseptal furrows, either on both their sides (cardinal, counter and counter-lateral) or only on their counter side (alar). The cardinal ridge is always located in the upper part of the corallite, in the plane of bilateral symmetry; the counter and counter-lateral ridges are in the opposite area (lower part of the calice).

Comments: 1) As with the Rugosa, and especially on the counter side, the septal ridges are set in a pseudo-radial pattern; 2) in some corallites, the central part of the alar furrows appears as a pair of subaxial depressions (Fig. 23D).

This is the first time that a Rugosa-like pattern of septal ridges has been recorded in the genus Parastriatopora, but it has been described previously in Kerforneidictyum (Lafuste \& Plusquellec 1976) and in Palaeacis (Plusquellec et al. 1990). These new data show once again the close relationship between Tabulata and Rugosa.

Family Pachyporidae Gerth, 1921

\section{Genus Thamnoptychia Hall, 1876}

Type species. - Madrepora limbata Eaton, 1832, non Goldfuss, 1826, syntypes from Darien and Genese valley, New York State, Hamilton Group, Middle Devonian.

\section{Thamnoptychia cf. T. limbata (Eaton, 1832)}

Figure 25

1965 Striatopora sp. - Branisa, pl. 48, fig. 14.

Among the specimens figured by Branisa (1965) and reported to be from Pisacaviña there are several small branches which he assigned to Striatopora sp. According to the morphology of the calices and to the transverse and longitudinal sections (made in illo tempore by the late W.A. Oliver), the so-called Sriatopora sp. can be assigned to Thamnoptychia cf. limbata, which is a common coral in the New York Hamilton Group (Givetian). In a letter to F. Tourneur regarding these specimens, Oliver wrote (1992): "We have 50+ fragments, possibly including some of the illustrated ones; Branisa told me that these are from the same locality as the illustrated specimens and the above, but our records are not completely clear" (sic). In addition, this kind of small branch has never been collected by Janvier, Gagnier \& Racheboeuf at Pisacaviña. Thus,

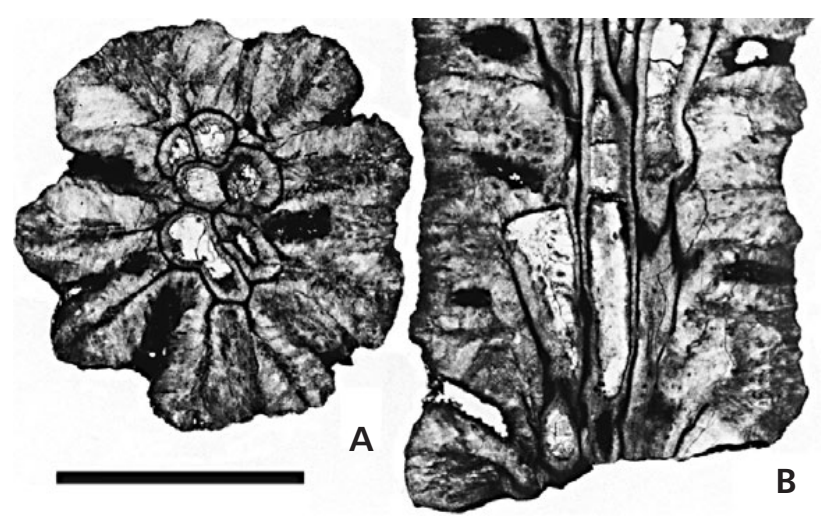

Figure 25. Thamnoptychia cf. T. limbata. Transverse and longitudinal sections in a branch. Scale bar $5 \mathrm{~mm}$.

they may have originated either from another locality near Pisacaviña, or from a different level to the one studied in this paper and consequently they are only figured here (Fig. 25), but not described. Nevertheless, it is extremely probable that the taxon occurs in Bolivia.

At Pisacaviña, a Late Emsian, or most probably Early Eifelian, age is assigned to the fauna. Although this may seem early for Thamnoptychia, it should be borne in mind that this genus is recorded in the late Emsian of the Cantabrian Mountains, Spain (Fernández-Martínez \& Tourneur 1995).

\section{Brachiopoda \\ (Patrick R. Racheboeuf)}

The chonetoidean brachiopods are among the most abundant and diversified components of the Bolivian Devonian invertebrate fauna. However, they range mainly from the Emsian to the Late Devonian, and the description of two Lochkovian new species adds to our knowledge of the Early Devonian Bolivian fauna.

Superfamily Chonetoidea Bronn, 1862

Family Strophochonetidae Muir-Wood, 1962

Subfamily Strophochonetinae Muir-Wood, 1962

\section{Genus Kentronetes Racheboeuf \& Herrera, 1994}

Type species. - Chonetes rücki Ulrich, 1893.

Type locality. - Between Totora and Chalhuani, Scaphiocoelia Zone, Early Pragian.

Remarks. - As presently known, the genus Kentronetes is biogeographically restricted to the Devonian of the Malvinokaffric Realm, in South Africa, Argentina, and Bolivia. 
The genus occurs from the lowermost to the uppermost beds of the Talacasto Formation of the Argentine Precordillera (K. variabilis, K. vallensis, K. ortegae, and K. giolitti in ascending order, Lochkovian to Emsian; Herrera 1995), from the Gydo and Voorstehoek formations of the Bokkeveld Group of South Africa (K. africanus, Emsian-Eifelian; Hiller 1995), and from the lowermost Belén Formation to the uppermost Icla Formation of Bolivia (K. ruecki, K. iclaense, and K. havliceki, latest Lochkovian to Eifelian; Racheboeuf 1985, Racheboeuf \& Isaacson 1994).

\section{Kentronetes giae sp. nov.}

Figure 26A-I

2003 Gen. et sp. nov. A, Toro et al., p. 259, pl. 1, fig. A, pl. 2, fig. A.

2003 Gen. et sp. nov. B, Toro et al., p. 261, pl. 1, figs B, C, pl. 2, fig. B.

2003 Nov. gen. et nov. sp. C, Toro et al., pl. 2, fig. C.

Holotype. - Ventral valve, No. FCGI 2742, Fig. 26E, F.

Etymology. - From 'Gi', a diminutive of Gabriela, to honour Gabriele Warnet.

Type locality. - Outcrop along the road from La Paz to Santiago de Collana, near Ñunumayani, about $20 \mathrm{~km} \mathrm{~S}$ of Apaña, coordinates W $67^{\circ} 59^{\prime} 608$, S $16^{\circ} 08^{\prime} 201$, altitude 4020 m (Fig. 2). Uncía Formation, Lochkovian.

Type horizon. - Uncía Formation, Lochkovian.

Material. - More than 60 specimens, silicified shells as well as outer and inner moulds of isolated valves, and articulated shells, No. FCGI 2742-2860.

Diagnosis. - A species of Kentronetes with small-sized shell; well developed median enlarged costa; three pairs of very long rectomorph or cyrtomorph symmetrically arranged spines; dorsal valve interior with faintly developed median septum.

Description. - Small-sized and thin shell, moderately transverse in outline, with maximum width at about midlength (maximum length: $6.9 \mathrm{~mm}$; corresponding width: $9.1 \mathrm{~mm}$; length-width ratio: 0.682 for 29 specimens). Longitudinal profile with weakly concave dorsal valve, and moderately convex ventral valve. Ventral valve covered with low, rounded, and relatively narrow radial costellae, with intervals of the same width; dorsal valve with rounded costellae, almost flattened at the top, wider than intervals. Costellae increasing first by intercalation then by bifurcation towards ventral shell margins, and increasing mainly by bifurcation on dorsal valve. Costellae number 6 to 7 per $\mathrm{mm}$ (rarely 8 per $\mathrm{mm}$ ) along anterior margin. Median enlarged costa well-differentiated, reaching the anterior margin.

A maximum of 3 pairs of spines, symmetrically inserted, was observed on each side of the posterior ventral margin. Their mean distribution in $\mathrm{mm}$ from beak is as follows for 2 to 20 measurements (numbers under slash): 3.05/4(3'), 1.39/20(2'), 0.31/4(1') - 0.29/2(1), 1.41/20(2), 3.04/6(3). Spines orthomorph perpendicular and/or weakly cyrtomorph intraverse, with well-marked and relatively spaced concentric growth lines. Spines very long, reaching more than three times the ventral valve length.

Ventral valve interior with a well-limited, concave visceral cavity, separated from the shell margin by a flat area devoid of radially arranged endospines. Teeth not observed. Myophragm reduced. Muscle field weakly impressed, posteriorly bounded by relatively well-developed, straight posterior ridges. Anterior adductor muscles well limited, elliptical in outline; posterior ones triangular, poorly limited anteriorly. Vascula media reduced. Between the muscle field and the peripheral margin, the ventral valve interior bears radial rows of small, spaced, well-differentiated endospines.

Dorsal valve interior flat with internally bilobed cardinal process elevated above the valve floor; inner socket ridges posteriorly concave, regularly arched, short and narrow, weakly prominent. Median septum low, narrow and short, not fused posteriorly with the cardinal process; no alveolus developed. Length of the septum not exceding one fifth the valve length. Straight, relatively long, and thin anderidia, anteriorly divergent at $60^{\circ}$, not fused posteriorly with the cardinal process. Muscle scars indistinct. Inner surface with radial rows of tiny, well differentiated, and spaced endospines.

Discussion. - This new strophochonetid species exposes all the morphological characters of the genus Kentronetes Racheboeuf \& Herrera, 1994. Externally, Kentronetes giae sp. nov. can easily be distinguished from the seven other species previously assigned to the genus Kentronetes by its smaller size with a maximum length of $6.9 \mathrm{~mm}$ and a corresponding width of $9.1 \mathrm{~mm}$, and a maximum of three pairs of symetrically inserted, rectomorph perpendicular and/or cyrtomorph intraverse spines. Other distinguishing character is the very weak development of the dorsal median septum. Compared with the two other well-known Bolivian species of the genus Kentronetes, namely K. ruecki (U1rich, 1893) from the lower part of the lower member of the Belén Formation, and K. iclaense (Racheboeuf \& Branisa, 1985) from the upper member of the Icla Formation. $K$. giae sp. nov. exhibits a set of characters (small size, low number of spines, and poorly developed dorsal median septum, among others) which can be regarded to represent 

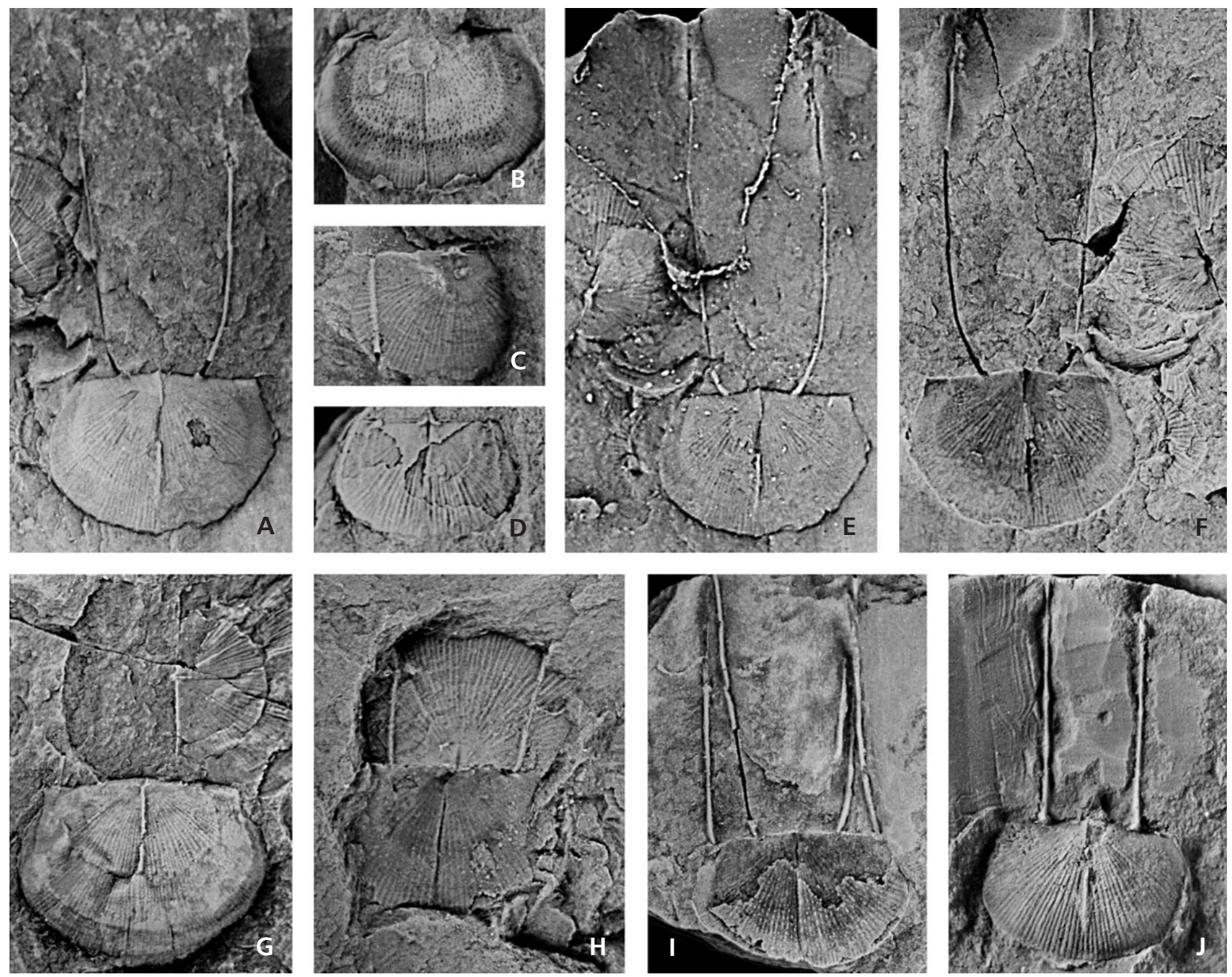

Figure 26. Chonetoidean brachiopods. Kentronetes giae sp. nov. from Ñuñumayani. • A - ventral valve, FCGI 2743 • B - ventral valve internal mould, FCGI 2744. • C - dorsal valve interior, latex cast, FCGI 2745. • D - dorsal valve interior, latex cast, FCGI 2746. $\bullet$ E, F - holotype. Ventral valve, latex cast and external mould; note the dorsal valve interior, FCGI $2742 \cdot \bullet \mathrm{G}$ - ventral and dorsal valve exteriors, FCGI $2747 \cdot \bullet \mathrm{H}-$ external mould of and articulated shell, FCGI 2748. • I - ventral valve external mould, FCGI 2749. • J - ventral valve, FCGI 2750. All specimens $\times 4$.

primitive characters among the Kentronetes lineage. This fits well with the stratigraphic position of the Nuñumayani locality for which an Early (?) Lochkovian age appears likely. This makes $K$. giae sp. nov. the first, and oldest representative of the genus which was up to now not known to occur below the Pragian-Emsian levels in Bolivia.

\section{?Kentronetes sp.}

Material and locality. - Two poorly preserved ventral valve exteriors from the Rumicorral locality, Kirusilla Formation, Interandean Zone, Lochkovian, FCGI 3577-3578.

Discussion. - The transverse and moderately convex, finely costellate ventral valves, with a long and narrow but welldeveloped median costa attest of their belonging to Stropho- chonetidae, and most probably to Kentronetes. However, the lack of any interior feature does not allow to establish this genus assignment. Specimen FCGI 3577 is $18 \mathrm{~mm}$ wide and $10.5 \mathrm{~mm}$ long (i.e. a length/width ratio about 0.58 ); its right posterior margin bears six spines. Along the anterior shell margin, costae and costellae number 4 to 6 per mm (about 21 per $5 \mathrm{~mm}$ ). The ventral interarea is apsacline and it bears a wide, triangular pseudodeltidium.

This form markedly differs from Kentronetes giae sp. nov. by its more transverse outline $(\mathrm{L} / \mathrm{W}$ ratio $=0.58$ instead of 0.68 ), and by a less dense ornament (4 to 5 per $\mathrm{mm}$ instead of 6 to 7). Moreover the median costa appears to be less developed. ?Kentronetes sp. can only be satisfactorily compared with $K$. variabilis from the lower part of the Talacasto Formation from the Argentine Precordillera, of Lochkovian age (Herrera 1995). However, although similar in outline and ornament, the Bolivian form is half the 

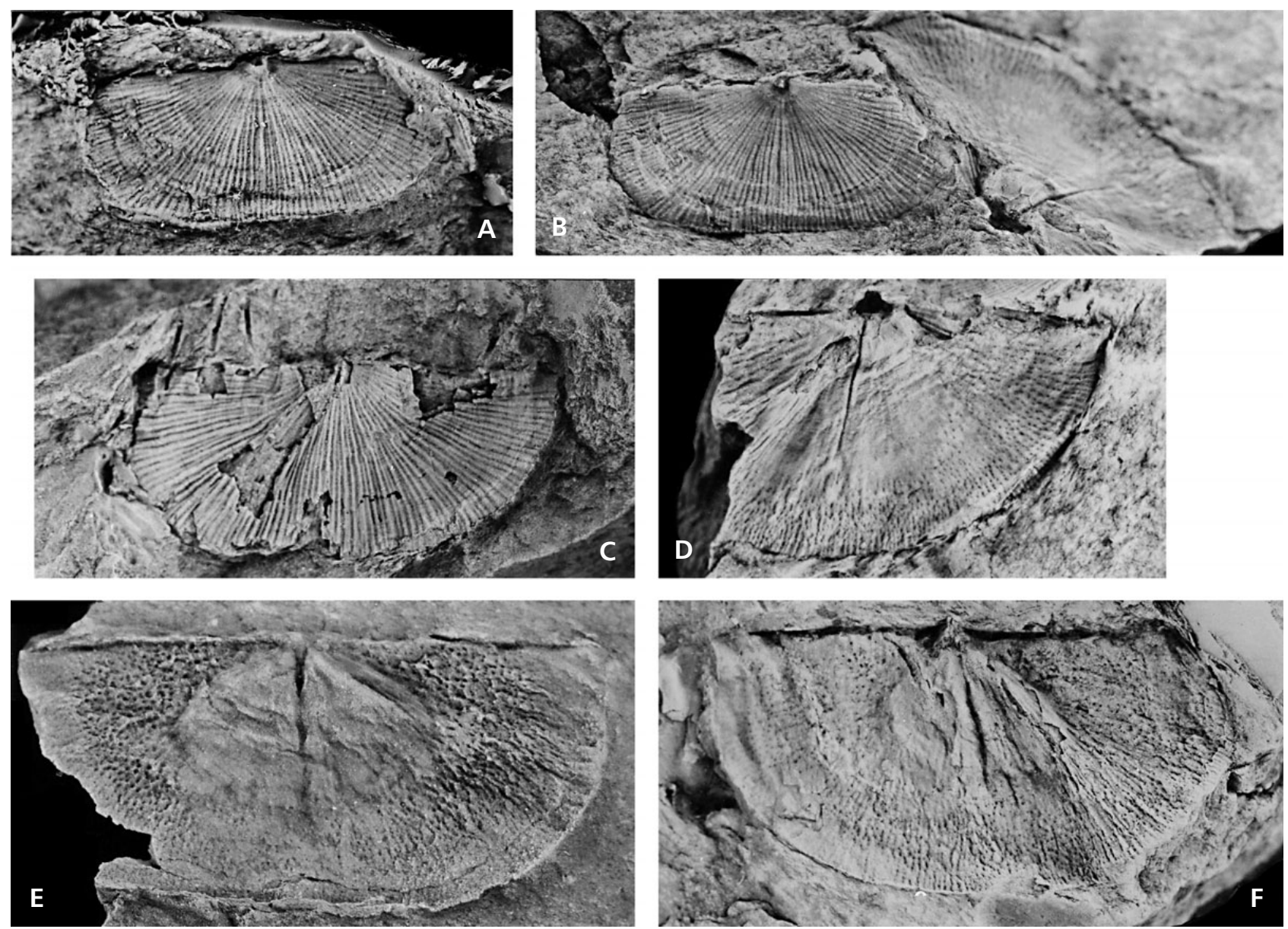

Figure 27. Chonetoidean brachiopods. Sanjuanetes glemareci sp. nov. from Muruhuta. $\bullet$ A, B - holotype. Ventral valve exterior, latex cast and external mould, FCGI 3536 . $\bullet$ - poorly preserved ventral valve showing spines, FCGI 3537 . $\bullet$ D -dorsal valve internal mould showing the long median septum, FCGI 3538 . E - ventral valve internal mould with well preserved muscle scars and myophragm, FCGI 3539 . $\bullet$ F - ventral valve internal mould, FCGI 3540. All specimens $\times 3$.

size of the Argentine one, and it bears more numerous spines (6 pairs of spines instead of 3 ).

\section{Genus Sanjuanetes Racheboeuf \& Herrera, 1994}

Type species. - Sanjuanetes dalenzae Racheboeuf \& Herrera, 1994.

Type locality. - San Juan boring (SIN.X2) of YPFB, N of Santa Cruz de la Sierra, Lochkovian.

\section{Sanjuanetes glemareci sp. nov.}

Figure 27A-F

Holotype. - Ventral valve external mould, No. FCGI 3536, Fig. 27A, B.

Etymology. - To honour my friend and colleague the retired
Prof. Dr. Michel Glémarec, one of the best and last autentic French marine biologists.

Material. - 24 isolated ventral and dorsal valves, exteriors and interiors, variably tectonically distorted, from the type locality, $1.5 \mathrm{~km} \mathrm{~N}$ of Muruhuta (FCGI 3536-3541; 3566-3568). An isolated ventral valve interior from the locality Huacallani, S of La Paz, is questionably assigned to the new species (FCGI 2880).

Type locality. - Outcrop along the road from Chacoma to Muruhuta, $1.5 \mathrm{~km}$ after Muruhuta. Coordinates: S1707' 009, W 6750' 944, altitude 3984 m. Muruhuta Shale Member, ?Př́idolian.

Type horizon. - Muruhuta Shale Mb., Př́ídolí.

Diagnosis. - A species of Sanjuanetes with relatively large shell with well-developped ventral median enlarged costa, and plano-convex to weakly resupinate profile; at least five 
pairs of orthomorph oblique spines; long ventral myophragm; long and stout dorsal septum supporting the cardinal process.

Description. - Shell middle-sized, markedly transverse, semicircular in outline, with maximum width at hinge line. Maximum length about $14 \mathrm{~mm}$; corresponding width about $29 \mathrm{~mm}$; length-width ratio varying between 0.44 and 0.56 , due to tectonic distorsion. Longitudinal profile moderately convexo-concave, becoming markedly convexo-concave along anterior margin. Ventral interarea relatively high, flat and apsacline, almost catacline, with a well-developed but short pseudodeltidium. Dorsal interarea low, strongly hypercline, almost catacline, in the same plane as the ventral one. Chilidial plates triangular, relatively large. Myophore triangular, wide, quadrilobed, with shallow muscle prints.

Shell surface costellate, with a rounded, well-differentiated ventral median enlarged costa reaching anterior margin. A median enlarged costa is also developed on the dorsal valve. Costae and costellae rounded, subsemicircular in cross section, widening anteriorly, with narrower intervals. Costellae increase by intercalation on the ventral valve, and only by bifurcation only on the dorsal valve. Along anterior margin costae and costellae number 3 to 4 per mm, with a maximum of 19 per $5 \mathrm{~mm}$.

Spines cyrtomorph intraverse proximally, becoming straight, orthomorph oblique distally, and relatively stout; at least five spines on each side of the beak, the first one (possibly the second one) being inserted at about $1.98 \mathrm{~mm}$ from beak (1') or at about $2.47 \mathrm{~mm}$ (1); but, due to tectonic distorsion, no mean values can be given.

Ventral valve interior with thin and low myophragm about two-thirds the valve length. Muscle field ill-defined on smallest available shells, becoming deeply impressed on the valve floor of largest specimens, with subtriangular, rounded adductors, and elongate, narrow, elliptical diductors. Posterior muscle bounding ridges faintly curved forewards toward midline. Hinge teeth relatively thick, anteriorly rounded, few extending alterally. Inner surface covered by numerous, radially but irregularly arranged endospines.

Dorsal valve interior with a long and stout median septum supporting the cardinal process. Anderidia short and narrow, low-angled. Inner sockets few extended laterally, and posteriorly weakly concave.

Discussion. - Despite the resupinate nature of largest specimens, although tectonically distorted, this form is assigned to the subfamily Strophochonetinae of the strophochonetids, rather than to the family Chonostrophiidae. Such an assignement mainly lies upon the external ornament, with the development of a median enlarged costa, and the lack of concentric fila. Within the family Strophochonetidae, the shell morphology and ornamentation, with a well differentiated median enlarged costa, and rounded costae and costellae originating by intercalation on ventral valve, makes the new species a representative of the genus Sanjuanetes.

Sanjuanetes glemareci sp. nov. differs externally from the type species Sanjuanetes dalenzae Racheboeuf \& Herrera, 1994, from the Early Lochkovian of the San Juan borehole (N of Santa Cruz de la Sierra, Subandean Zone) by its larger and more transverse shell, with a well-developed resupinate profile. Moreover, its external ornament is stouter with typically rounded costae and costellae.

The unique ventral valve from Huacallani can only be questionably assigned to the new species (Sanjuanetes $\mathrm{cf}$. S. glemareci sp. nov.). The shell is somewhat larger, less transverse and more rounded in outline, and its preservation does not allow any detailed morphological comparison (ornamentation indistinct, lack of spines, etc.).

Family Chonostrophiidae Muir-Wood, 1962

\section{Genus Chonostrophia Hall \& Clarke, 1892}

Type species. - Chonetes reversa Whitfield, 1882.

Type locality. - Smith and Prices quarries, Columbus (Ohio), Marcellus Shales, Middle Devonian.

\section{Chonostrophia cf. C. truyolsae Racheboeuf, 1998} Figure 28A-E

Material. - 13 isolated, more or less complete ventral and dorsal valves, exteriors and interiors, and two articulated shells, all decalcified and well preserved, from the outcrop along the football field of Pisacaviña. Two more specimens, a ventral interior and a juvenile complete shell, from Chiar Umani in float concretions are assigned to the same form (FCGI 3542-3565).

Discussion. - Among previously described chonostrophiids, this form can only be compared with C. truyolsae Racheboeuf, 1998 from the uppermost Icla and lowermost Huamampampa formations of the Subandean Zone of Bolivia (section $\mathrm{S}$ of Presto, Eifelian). Specimens from both localities exhibit similar small-sized shell, but the maximum width seems always located at hinge line (with concave posterolateral commissures) in C. cf. C. truyolsae. In specimens of $C$. truyolsae the maximum width is located at the hinge line, with lateral commissures perpendicular to hinge line, and it migrates anteriorly with shell growth. Moreover $C$. truyolsae never develops a resupinate anterolateral margin with growth. Spines are less numerous (4 pairs instead of 6) in C. truyolsae, and always 

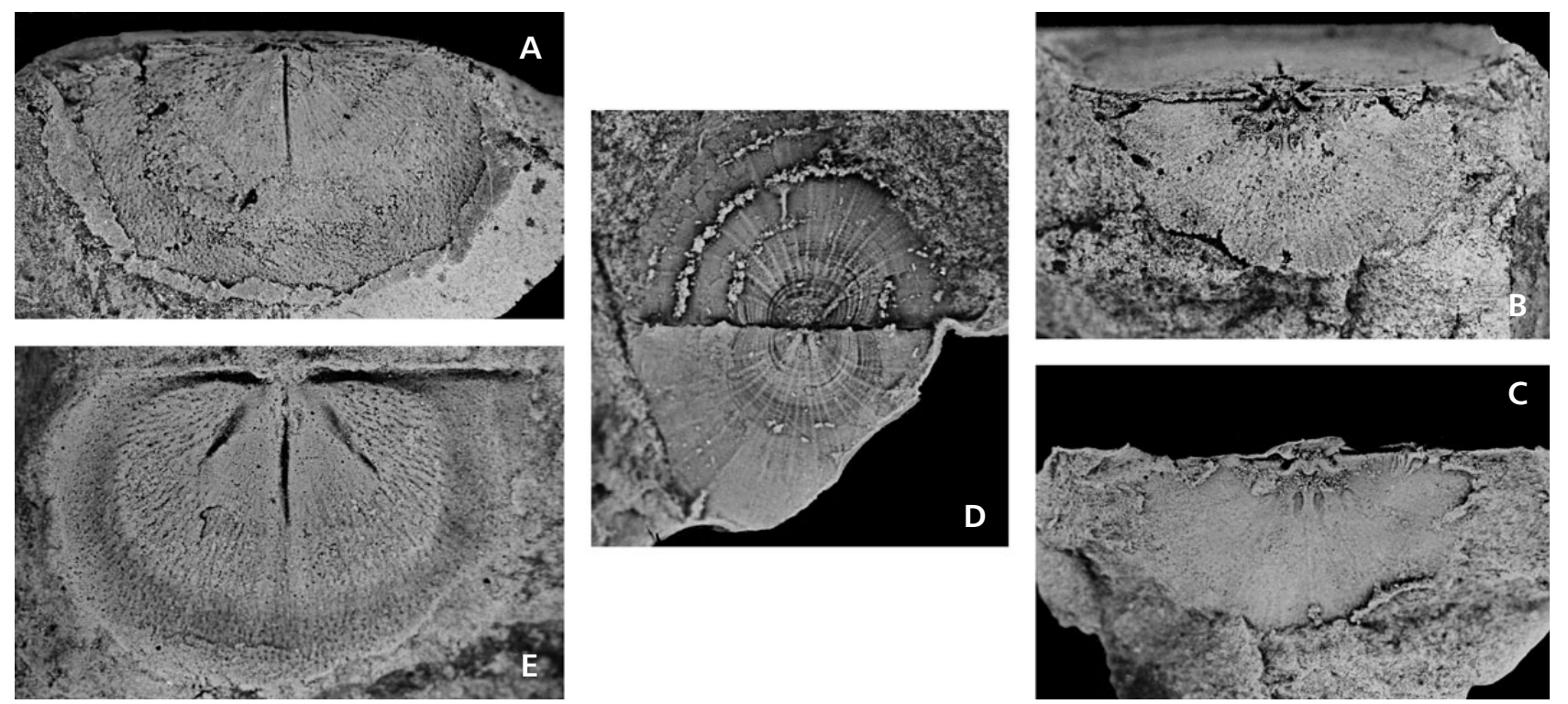

Figure 28. Chonetoidean brachiopods. - A-D - Chonostrophia sp. cf. C. truyolsae from Pisacaviña; A-C - articulated shell, ventral valve internal mould (A), dorsal valve internal mould and hinge line (B), and latex cast of the dorsal valve (C), FCGI 3542, D - latex cast of the exterior of an artculated shell, FCGI 3543. • E - ventral valve internal mould from Chiar Umani, FCGI 3544. All specimens $\times 4$.

orthomorph oblique. However more material is needed before any potential new species is described.

\section{Trilobites \\ (Maria da Gloria Pires de Carvalho)}

All the trilobite fossils described below have been collected during the 2009 field work session in Bolivia.

Family Homalonotidae Chapman, 1890

Homalonotid gen. et sp. indet.

Figure 29A-D

Occurrence. - Kirusilla Formation, at Rumicorral, $22.7 \mathrm{~km}$ E of Aiquile, Lochkovian, close to the type locality of Legrandella Eldredge, 1974 (the age of which is not yet well established), Subandean Zone.

Material. - Internal moulds of an incomplete and poorly preserved pygidium, an almost complete cephalon, and part of a pygidial doublure (FCGI 3571-3573).

Description. - The cephalon is wider than its sagittal length (18.6 mm / $11.4 \mathrm{~mm}$ sag.), with smoothly rounded and gently convex lateral margins becoming slightly concave towards the sagittal line, and with a low projection at the anterior midline. The preglabellar field is narrow. The glabella is only slightly elevated and its shape is not well defined, although it may be weakly urceolate, with a shallow, weakly impressed axial furrow. Glabellar furrows and lobes are indistinct. The cephalic posterior border broadens slightly abaxially, with a smooth posterior margin and a rounded genal angle. The posterior border furrow is narrow and well impressed. The cheeks are moderately convex, with very small, slightly elevated eyes situated distally. The rostral plate is triangular, wider than long (sag.), and depressed medially. From the posterior margin of the eye, the posterior branch of the facial suture extends laterally rather than posterolaterally to the cephalic lateral margin, and is gently convex anteriorly. The anterior branches of the facial suture are weakly sigmoidal and meet on the dorsal surface of the preglabellar field approximately at mid-way between the anterior cephalic margin and the faint anterior glabellar furrow. The entire surface of the internal mould of the cranidium is covered by pits.

Few features are evident in the poorly preserved pygidium. It is subtriangular in outline, with smoothly curved margins meeting posteriorly to form a subdued point. The pygidium is moderately convex (tr.), with weak trilobation, weak segmentation, and a low posterior axial swelling. Part of the doublure is exposed in ventral view, revealing a scale-like ornamentation.

Remarks. - Sandford (2005) recognized three genera of Silurian and Devonian homalonotids in Bolivia (Burmeisteria, Dipleura, Trimerus), although previous investigators have reached different conclusions (Kozlowski 1923, Branisa 1960, Wolfart 1968) and the systematics of these forms probably requires revision. The material reported 
here is so incomplete that it is difficult to identify even at generic level, and it is possible that more than one taxon is represented, but a few observations are possible.

The preglabellar field, the glabella shape, and the course of the anterior branch of the facial suture are quite similar to Burmeisteria. However, differences are noted in the lobation of the glabella, the shape, trilobation, segmentation, and ornamentation of the pygidium. The material differs from Dipleura in lacking a well developed preglabellar field, but is similar in the obsolete lobation of the glabella and the indistinct and faint trilobation and segmentation of the pygidium. The taxon studied here is readily distinguished from Trimerus by the lack of a well developed preglabellar field, and the obtusely pointed posterior end of the pygidium (this is more acuminate in Trimerus). Since it was not possible to identify such poorly preserved material to genus, it is uninformative regarding its precise stratigraphical age.

Family Dalmanitidae Vogdes, 1890

Subfamily Dalmanitinae Destombes, 1972

\section{Genus Kazachstania Maksimova, 1972}

Type species. - Dalmanites saryarkensis Maksimova, 1960, Late Silurian (Kokbaytal Stage, Ludlow?), central Kazakhstan.

\section{Kazachstania cf. K. gerardoi Edgecombe \& Ramsköld, 1994}

Figure 29G

Occurrence. - Uncía Formation at Ñuñumayani (S of Apaña and SE of La Paz, in the Eastern Cordillera Zone of the Bolivian Altiplano), Lochkovian.

Material. - One internal and external mould of pygidium, FCGI 3574.

Description. - The pygidium is triangular in outline, with $25.0 \mathrm{~mm}$ maximum width anteriorly and $20.8 \mathrm{~mm}$ of length (sag.), including the mucro, weakly convex (tr.), with lateral margins gently bulged, becoming slightly concave near to the short, triangular mucro. Anteriorly, the maximum width of the axis is a little more than $1 / 4(=5.8 \mathrm{~mm})$ of the maximum width of the pygidium and is not much more than half the width of the anterior pleural lobe $(9.6 \mathrm{~mm})$. The pygidium tapers evenly backward and is composed of 15-?16 axial rings plus a blunt terminal piece. The axial terminus grades into a very weak median keel that ends before reaching the mucro. The first six axial rings are slightly bowed anteriorly but the subsequent ones are almost straight. The first three or four rings have small pseudo-articulating half rings. There are about 10-?11 pleural furrows; these are narrow and deepest near the axial furrow, gently widening toward the lateral margin. Pleural furrows are thinner and more linear.

Remarks. - The sample is represented by a single pygidium preserved as internal and external moulds. The shape, the number of the axial rings and pleurae, and the short, triangular mucro resemble Kazachstania gerardoi from the Early Devonian (Lochkovian) of the Catavi Formation southeast of Cochabamba, central Bolivia (Edgecombe \& Ramsköld 1994). The pygidium differs from that of $K$. andii Pek \& Vaněk, 1991 from the Uncía Formation (Altiplano) in having a lower number of axial rings (15-?16; 17) and pleurae (10-?11; 12); additionally, K. andii has a longer pygidium and a narrower pygidial axis (the anterior maximum width is less than half of the pleural lobe). In the absence of cephalic material, its identification remains uncertain.

Family Odontopleuridae Burmeister, 1843

Subfamily Odontopleurinae Burmeister, 1843

\section{Genus Kettneraspis Prantl \& Přibyl, 1949}

Type species. - Acidaspis pigra Barrande, 1872, Acanthopyge Limestone (upper Eifelian), Bohemia, the Czech Republic.

Stratigraphic range. - Middle Silurian to Middle Devonian.

Kettneraspis aracana? (Steinmann, 1912)

Figure 29E, F

Occurrence. - Uncía Formation at Ñuñumayani (S of Apaña and SE of La Paz), in the Eastern Cordillera Zone of the Bolivian Altiplano, and the Kirusilla Formation at Rumicorral (22.7 km E of Aiquile), in the Interandean Zone, Lochkovian.

Material. - Internal and external moulds of parts of the thorax and pygidium, poorly preserved (FCGI 3575-3576).

Remarks. - In the absence of a cephalon or of well preserved thoracic axial rings and pleurae, it is difficult to make a precise identification since the arrangement, size and number of granules on the thoracic axial rings and pleurae are important for specific classification. The material is tentatively referred to Kettneraspis aracana. The pygidia recently collected by Crasquin \& Racheboeuf from the Uncía and Kirusilla formations are very similar and are therefore considered to be conspecific. They bear three paired spines: a small one medially, a second longest pair positioned exsagitally, and a third (smallest) pair positioned abaxially. 

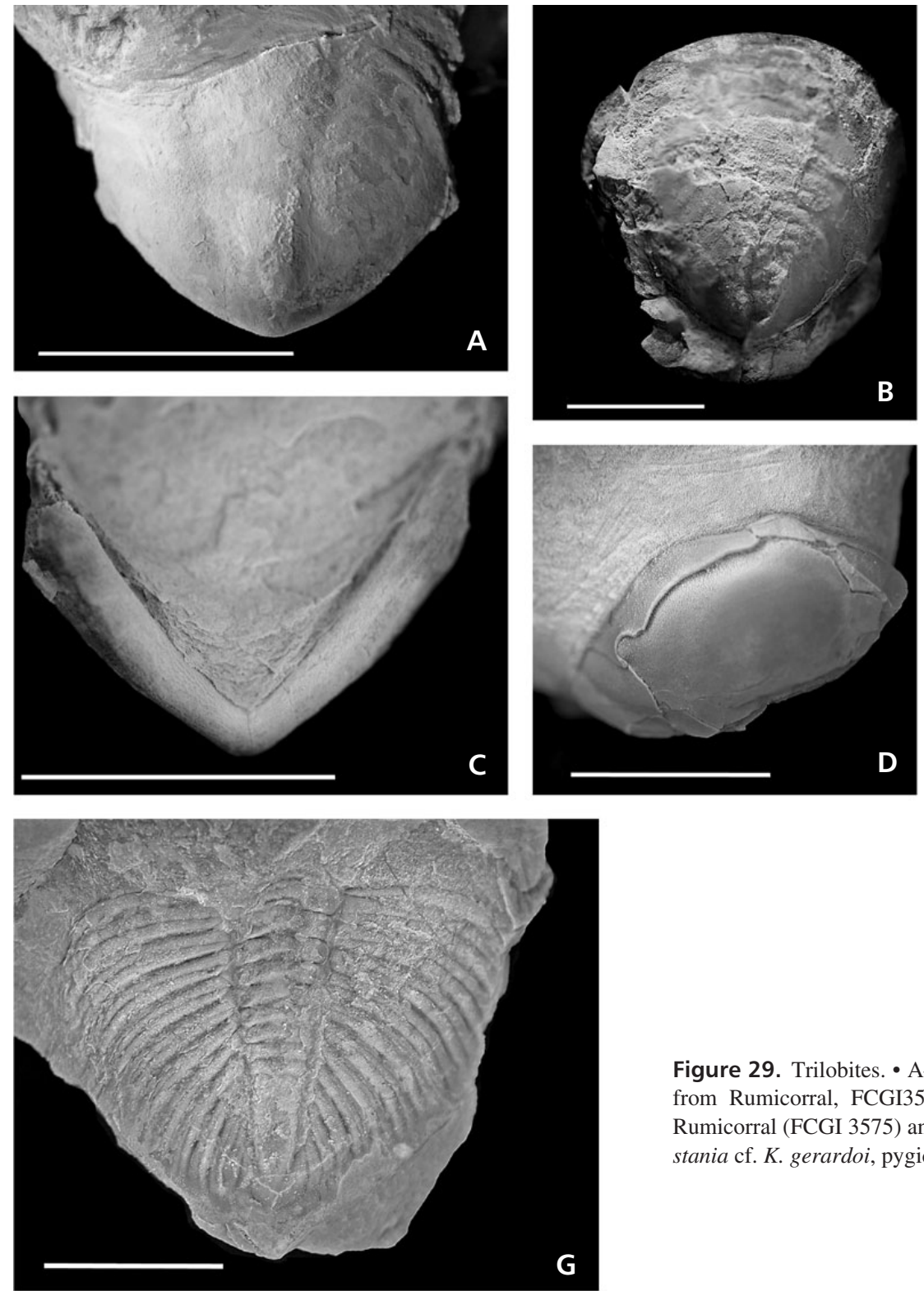

Six or seven thoracic pleural spines extend behind the posterior border of the body of the pygidium. These observations agree with those made by Ramsköld \& Chatterton (1991, p. $358)$ in their Kettneraspis material. According to these authors, Kettneraspis is pandemic, but it shows indications of provincialism among subgroups. Three species of Kettneraspis have been documented from the Uncía Formation (Altiplano Zone): K. aracana (Steinmann, 1912), K. chacaltayana (Kozlowski, 1923), and K. berryi (Swartz, 1925). Ramsköld \& Chatterton (1991) regarded the Bolivian Kettneraspis species as Lochkovian in age.

In addition to these records, Edgecombe (2000) documented Kettneraspis sp. from the El Carmen Formation in SE Bolivia, and concluded that the trilobite assemblage there suggests the Přídolian to Early Lochkovian age. The material
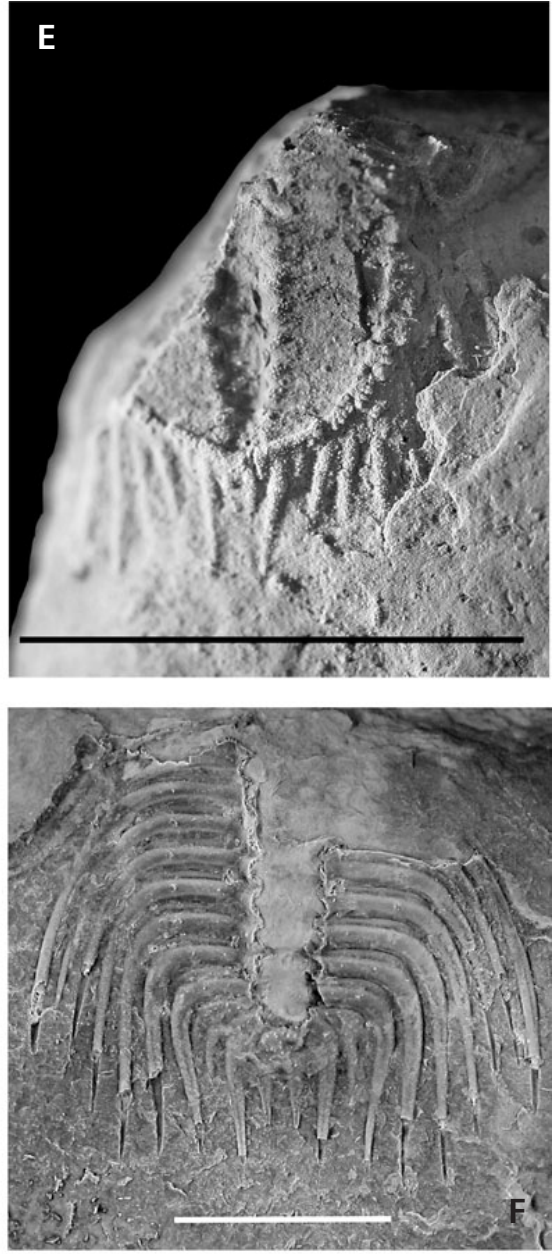

Figure 29. Trilobites. - A-D - homalonotid gen. et sp. indet., all specimens from Rumicorral, FCGI3571-3573. • E, F - Kettneraspis aracana? from Rumicorral (FCGI 3575) and from Nuñumayani (FCGI 3576). • G - Kazzachstania cf. K. gerardoi, pygidium from Ñuñumayani (FCGI 3574).

described here represents the first record of $K$. aracana from the Subandean Zone of Bolivia and possibly expands its geographic range beyond the Altiplano. To summarize, the genus Kettneraspis suggests a Př́idolian-Lochkovian age, but $K$. aracana is probably Lochkovian.

\section{Ostracoda \\ (Jean-Georges Casier)}

As a whole, South American Paleozoic ostracods are still poorly known. The rare published studies are based on a small number of samples from isolated localities yielding an ostracod fauna nearly exclusively preserved as internal and external moulds. According to literature, South American 
Ordovician to Devonian ostracods have been described, mainly from Bolivia, by Pinto \& Purper (1981), Přibyl (1984a, b), Vannier et al. (1995), and Lethiers et al. (2001) reported some Givetian ostracods from Bolivia.

Material and methods. - Ostracods have been extracted from a ferrugineous thin layer overlaying the surface of a massive ( $15 \mathrm{~cm}$ in diameter) silicified limestone lens rich in dislocated skeletal elements of crinoids. The majority of ostracods are preserved as internal and external moulds, and about 200 were selected for the study. Some internal moulds have been extracted with a needle. Internal and external moulds of skeletal elements of crinoids, small brachiopods, gastropods and pelecypods are associated with the ostracod fauna. We have tried to extract ostracods from the massive silicified limestone containing crinoids, by the hot acetolysis method (Lethiers \& Crasquin-Soleau 1988), but without any results. For the study we have also made some latex casts.

\section{Comparison with previously described ostracod faunas}

The ostracods described from Pisacaviña are poorly preserved and consequently all the species are in open nomenclature. Moreover, the majority of genera are also recognized with reservation. But all the ostracods described from South America are poorly preserved, and composed quasi exclusively of internal and external moulds. Consequently, comparisons are very difficult to establish.

Zudanezina Přibyl, 1984, is a genus known in the Early and Middle Devonian of Bolivia, but Zunadezina zudanezensis Přibyl, 1984b, and Zunadezina undata Lethiers, 2001, do not show the reticulated ornamentation observed in Zudanezina? sp. A. Moreover, the lobe is more accentuated in these two species and does not have the same shape. Zunadezina zudanezensis has been described from the Early Devonian in the Zudañez Province, and Zunadezina undata from a Givetian section in the Santa Cruz Province.

Keslingiella sp. A, aff. K. pillai Pinto \& Purper, 1981, is possibly a synonym of Menoeidina? boliviana Přibyl, 1984, from the Early Devonian of the Zudañez Province, but the material on which the species is defined is too poorly preserved. Keslingiella cf. pillai described by Lethiers (in Lethiers et al. 2001) from a Givetian section in the Santa Cruz Province, seems very close the species described herein. Keslingiella pillai Pinto \& Purper, 1981, is a species described from the Silurian Torro Formation in the Santa Cruz Province.
Favulella? sp. B could be a synonym of Gen. 5 sp. B sensu Becker \& Bless in Becker et al. (1994). That species described from the Emsian of the Gydo Formation in South Africa, also possesses a rough ornamentation and a very large smooth surface along the free margin. Some similarities exist also with 'Jenningsina' sp. nov. A in Lethiers et al. (2001) from a Givetian section in the Santa Cruz Province.

Kloedenelloidea sp. indet. presents some similitude with the Kloedenelloidea sp. indet. described by Lethiers et al. (2001) from the Givetian of the Iquiri Formation in the Santa Cruz Province, and also with Gen. 3 sp. A described by Becker et al. (1994) from the Eifelian Waboomberg Formation of the Southern Cap, South Africa.

Finally, Favulella? sp. A is very close to Favulella favullosa Jones 1889 sensu Swartz \& Swain (1941), a species described from the Early Devonian of the Onondaga Formation in Pennsylvania (USA).

Except for Favulella? sp. A, no taxonomic relationship seems to exist with the fauna described from other South American countries, mainly from Argentina (Baldis \& Rossi de García 1975, Rossi de García \& Proserpio 1976), nor with the generally well preserved fauna from North America, Europa and North Africa. That confirms the endemism of the Bolivian ostracod fauna which belong to the so-called Malvinokaffric Realm of Boucot (1988). That has been previously pointed out by Lethiers et al. (2001) for the Givetian fauna from the Iquiri Formation of the Santa Cruz Province.

The age of the sample from Pisacaviña is consequently difficult to establish with the ostracod fauna. Nevertheless we can assume that the sample is Early Devonian or Eifelian in age, as indicated by the abundance of specimens belonging to the genera Ulrichia Jones, 1890, and Drepanella Ulrich, 1894. The absence of these two genera in the fauna described recently from Bolivia by Lethiers et al. (2001), indicates undoubtedly a younger age for the Iquiri Formation.

Order Palaeocopida Henningsmoen, 1953

Suborder Palaeocopina Henningsmoen, 1953

\section{Palaeocopina indet. 1}

Figure 30A

Remarks. - Two elongate amplete internal moulds display a straight dorsal margin and a slightly convex ventral margin. The anterior and posterior margins are slightly curved and nearly perpendicular to the dorsal border. A small

Figure 30. Ostracods. $\bullet$ A - Palaeocopina indet. 1. Internal mould of a right valve. FCGI 3514, $\times 65$. B - Palaeocopina indet. 2 . Internal mould of a left valve. FCGI $3515, \times 55$. C - Ulrichia sp. A. External mould of a left valve. FCGI 3516, $\times 55$. $\bullet$ D - Ulrichia sp. A. Internal mould of a right valve. FCGI $3517, \times 35 . \bullet$ E - Ulrichia? sp. indet. Internal mould of a right valve. FCGI $3518, \times 60 . \bullet$ F - Drepanella sp. A. Internal mould of a right valve. FCGI 3519 , $\times 40 . \bullet \mathrm{G}-$ Drepanella sp. A. Internal mould of a right valve. FCGI 3520, $\times 35 . \bullet \mathrm{H}-$ Drepanella sp. A. Internal mould of a right valve. FCGI $3521, \times 50$. $\bullet$ I-Drepanella sp. A. Internal mould of a left valve. FCGI 3522, × 40. $\bullet$ J - Kloedenelloidea sp. indet. Internal mould of a left valve. FCGI $3523, \times 35$. 

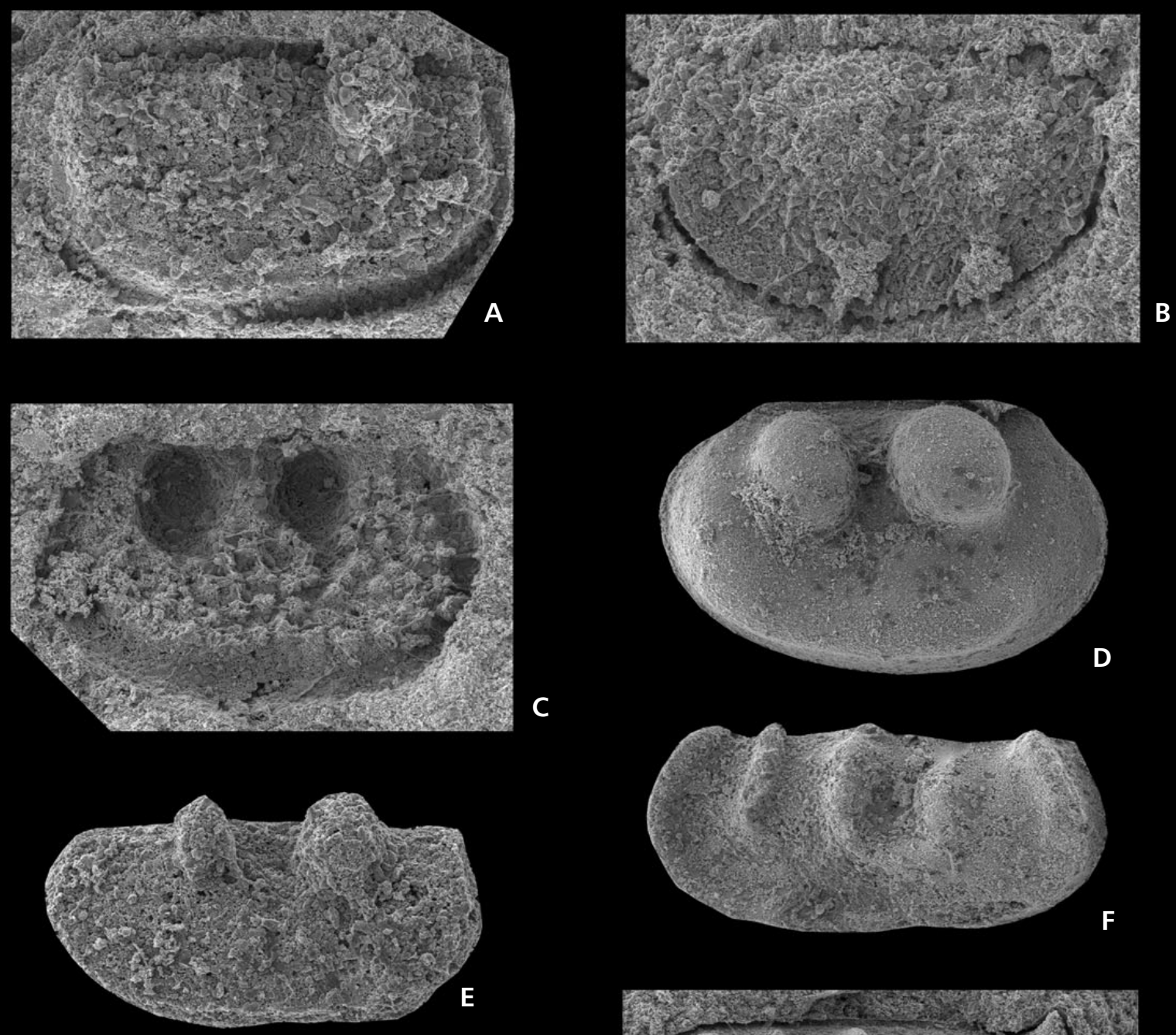

C
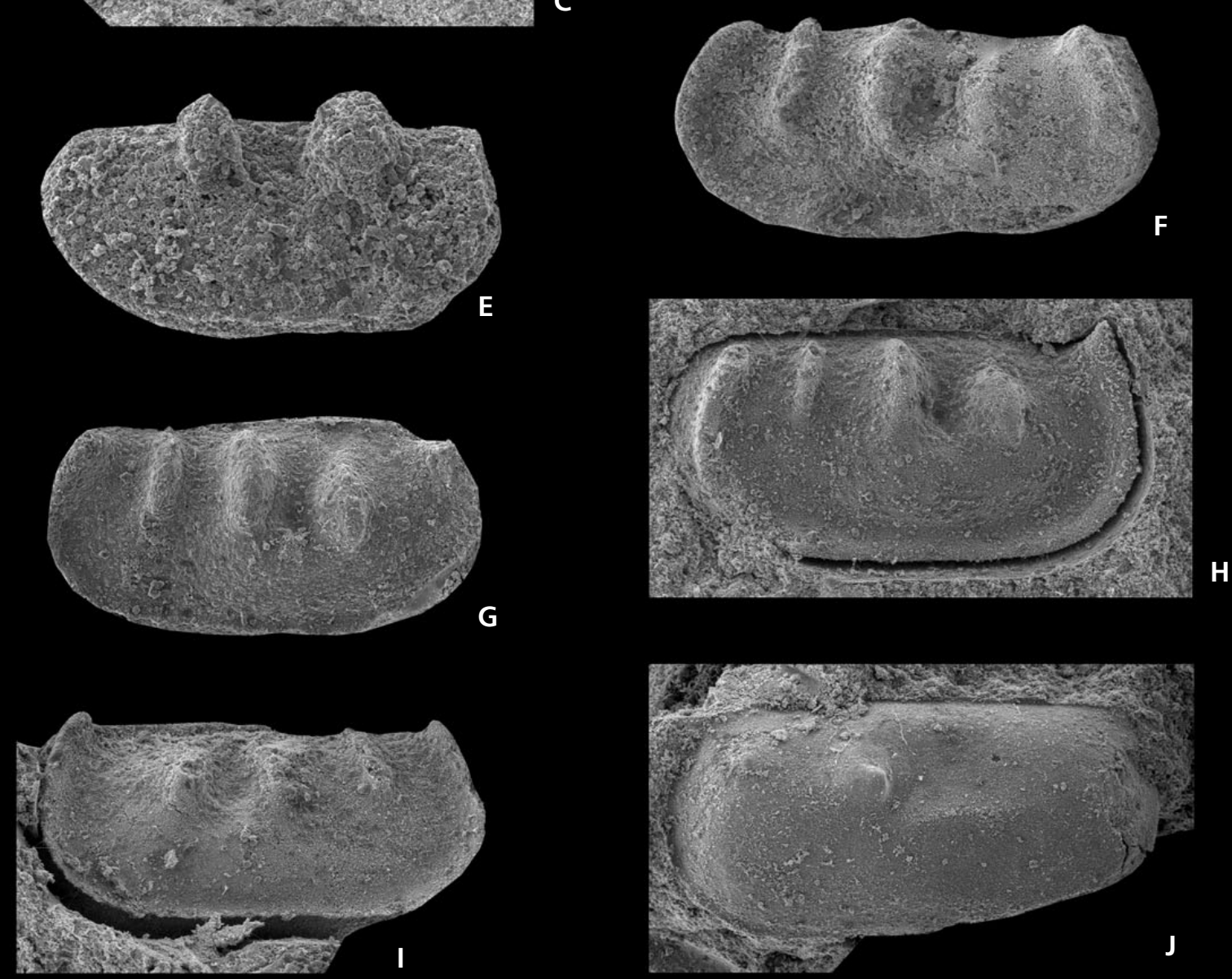
circular lobe is visible in the postero-dorsal sector and an other lobe is probably present in the central sector. A marginal structure seems to be present along the free margin.

\section{Palaeocopina indet. 2}

Figure 30B

Remarks. - A semicircular flat internal mould with a straight dorsal border seems to display a marginal structure all along the free margin.

Superfamily Drepanelloidea Ulrich \& Bassler, 1923

Family Bolliidae Bouček, 1936

\section{Genus Ulrichia Jones, 1890}

Type species. - Ulrichia conradi Jones, 1890, Middle Devonian, Ontario, Canada.

\section{Ulrichia sp. A}

Figure 30C, D

Remarks. - Seven very large preplete internal and external moulds display a straight dorsal border, a moderately curved ventral margin, and highly curved anterior and posterior margins. Two well rounded large lobes are prominent but not beyond the dorsal border. A sort of crescent-shaped flange is visible from the antero-ventral part to the posteroventral part of the valves. A reticulated ornamentation is observable on a single external mould, but the flange and the surface between this one and the free margin are smooth.

\section{Ulrichia? sp. indet.}

Figure 30E

Remarks. - An elongate internal mould in poor state of preservation presents two narrow lobes prominent beyond the dorsal border. A marginal ridge extends from the anterior extremity of the hinge to the antero-ventral sector.

\section{Genus Drepanella Ulrich, 1890}

Type species. - Drepanella crassinoda Ulrich, 1890, Ordovician, North America.

\section{Drepanella sp. A}

Figure 30F-I

Remarks. - Twenty-five internal and external moulds, the latter generally poorly preserved, are reported to the genus Drepanella Ulrich, 1890. They are large sized, elongate, amplete and their dorsal border is straight or slightly sinuous. The ventral margin is nearly straight and the anterior and posterior margins are regularly rounded. Three lobes are visible. The median and posterior lobes (L2 and L3) are narrow and elongate comparatively to the more rounded anterior lobe (L1). Occasionally the two posterior lobes are slightly prominent dorsally, and the two anterior are connected ventrally. A velate ridge is present all along the free margin, and its extremities are also frequently prominent dorsally. The ornamentation is probably finely punctuate.

Suborder Platycopina Sars, 1866

Superfamily Kloedenelloidea Ulrich \& Bassler, 1908

\section{Kloedenelloidea sp. indet.}

Figure 30J

Remarks. - Thirteen elongate very large and preplete internal and external moulds with a straight dorsal border display a small rounded lobe on the first third of the length. Two elongate delicate crests parallel to the dorsal border are occasionally present. The first one is short and at mid-height, the second is longer and in the mid-ventral sector.

Order Podocopida Sars, 1866

Suborder Metacopina Sylvester-Bradley, 1961

Superfamily Thlipsuroidea Ulrich, 1894

Family Quasillitidae Coryell \& Malkin, 1936

\section{Genus Keslingiella Pinto \& Purper, 1981}

Type species. - Keslingiella pillai Pinto \& Purper, 1981, Silurian, Santa Cruz Province, Bolivia.

\section{Keslingiella sp. A, aff. K. pillai Pinto \& Purper, 1981} Figure $31 \mathrm{~A}-\mathrm{D}$

Remarks. - More than hundred large internal and external moulds are closely related to Keslingiella pillai. They are amplete to slightly preplete with a curved or nearly straight dorsal border and a straight to slightly concave ventral margin. The anterior and posterior margins are regularly rounded. A discrete very shallow medio-dorsal V-shaped sulcus is observable on internal moulds. The rounded muscular scar, located in the median sector, is slightly larger than the ornamentation which is roughly punctuated. An internal mould, shows that the muscle scar is composed of numerous little spots. A marginal ridge which is more visible close to the anterior and posterior margins is present. The surface between that marginal ridge and the free 
margin is smooth. Two little spines are sometimes present: the first one is located in the postero-dorsal sector of the valves, and the second one in the postero-ventral sector. In dorsal view, the internal moulds are slightly pinched close to the medio-dorsal sulcus.

Family Bufinidae Sohn \& Stover, 1961

\section{Genus Bufina Coryell \& Malkin, 1936}

Type species. - Bufina elata Coryell \& Malkin, 1936, Middle Devonian, Ontario, Canada.

\section{Bufina? sp. A}

Figure $31 \mathrm{G}$

Remarks. - Four internal moulds display a spine in the postero-ventral sector, another spine in the postero-dorsal sector, and a marginal ridge along the anterior margin forming a sort of spur dorsally. The ornamentation is probably reticulated.

\section{Bufina? sp. B}

Figure $31 \mathrm{H}$

Remarks. - An elongate internal mould shows a continuous marginal ridge extended along the ventral, anterior and dorsal margins. The extremities of that ridge close to the posterior margin, in the postero-dorsal and postero-ventral sectors, are spiny. The surface of the valve is probably punctuate.

Family Thlipsuridae Ulrich, 1894

\section{Genus Favulella Swartz \& Swain, 1941}

Type species. - Bythocypris favulosa Jones, 1889, Middle Devonian, Pennsylvania, USA.

Favulella? sp. A, aff. F. favulosa Jones, 1889 sensu Swartz \& Swain, 1941

Figure 31F

Remarks. - A roughly punctuate valve displays a spur in the postero-ventral sector and a thickening in the dorsal sector. The ventral and dorsal margins are straight. The anterior margin is angular and the extremity is located slightly below the mid-height. The posterior margin is regularly curved. A marginal ridge is visible all along the free margin. That ridge is more developed anteriorly and especially posteriorly. The surface between that marginal ridge and the free margin is smooth.

\section{Favulella? sp. B}

Figure 31E

Remarks. - Two roughly punctuate thick broken valves display an outline similar to Keslingella sp. A, but the marginal ridge is more developed, and the smooth surface between that ridge and the free margin is larger.

?Family Thlipsuridae Ulrich, 1894

\section{Genus Zudanezina Přibyl, 1984}

Type species. - Zudanezina zudanezensis Přibyl, 1984, Lower Devonian, Zudañez Province, Bolivia.

\section{Zudanezina? sp. A}

Figure 31I, L

Remarks. - Five very large internal and external moulds are placed close to the genus Zudanezina Prribyl, 1984. Their dorsal border is straight, and their ventral margin is also straight or slightly convex. The anterior margin is regularly curved and the curvature of the posterior margin is more accentuate dorsally. A large lobe forming a buckle opened in the medio-dorsal sector, extends from one extremity to the other. The surface of the valves is finely reticulated except on the lobe.

Suborder Podocopina Sars, 1866

Superfamily Bairdioidea Sars, 1888

Family Bairdiidae Sars, 1888

\section{Genus Bairdia McCoy, 1844}

Type species. - Bairdia curta McCoy, 1844, Lower Carboniferous, County Longford, Ireland.

Bairdia? sp. indet.

Figure $31 \mathrm{~K}$

Remarks. - A very large left valve should be reported to the genus Bairdia McCoy, 1844.

Superfamily Bairdiocyprioidea Shaver, 1961

Family Bairdiocyprididae Shaver, 1961

Genus Bairdiocypris Kegel, 1932

Type species. - Bythocypris (Bairdiocypris) gerolsteinensis Kegel, 1932, Middle Devonian, Rheinischen Schiefergebirges, Germany. 


\section{Bairdiocypris? sp. indet.} Figure 31J

Remarks. - A large broken right valve should be reported to the genus Bairdiocypris Kegel, 1932.

\section{Ostracods palaeoecology}

Three ostracod mega-assemblages are recognized in the Devonian (Casier 2004): 1. The Myodocopid Mega-Assemblage characterised by Entomozoidea and (or) Cyprinoidea is indicative of poorly oxygenated marine environments; 2 . The Thuringe Mega-Assemblage characterised by thin shelled spiny ostracods is indicative of very calm deep and (or) cold environments; 3. The Eifelian MegaAssemblage is indicative of shallow marine, semirestricted and restricted environments. The Thuringian and the Eifelian Mega-Assemblages correspond to the Thuringian and to the Eifelian ecotypes of Becker (in Bandel \& Becker 1975). We have still reported (Casier 2004, Casier et al. 2005) that the term 'ecotype' seems inappropriate to characterise such ostracod assemblages because that term describes a group of specimens within a single species, and adapted genetically to a particular habitat.

The fauna from Pisacaviña is moderately diversified, and only 14 taxa have been recognized. The fauna is largely dominated by the Palaeocopina ( 5 species) and the Metacopina (6 species). The Platycopina are represented by one species, and the Podocopina by two specimens representative of two species. In the Devonian, such a fauna belongss to the Eifelian Mega-Assemblage which is subdivided in several assemblages characteristics of lagoonal environments (Ass. 0), semi-restricted environments (Ass. I), marine environments above fair weather wave base (Ass. II), and open marine environments below fair weather and sometimes below storm wave bases (Ass. III) (Casier 1987). The fauna of Pisacaviña belongs to this last assemblage. In the Ass. III, the relative abundance of species of Podocopina and Metacopina changes with the deepening, and is related to the agitation of the environment and to the oxygenation of the waters (Casier 1987). In our sample, the great abundance of Metacopina com- paratively to the Podocopina, and in particular to the Bairdioidea, indicates a slightly hypoxic very calm environment well below fair weather wave base. This is confirmed by the prevailing monospecificity: only one species, Keslingiella sp. A., aff. pillai Pinto \& Purper, 1981, is present in great individual abundance. This is also confirmed by the presence of numerous Palaeocopina, and some lingulids, chonetaceans and small pelecypods. The presence of spines on some metacopid species also confirms that the fauna is indicative of a very calm environment. In the Late Devonian of the Paleotethys, Favulella lecomptei spissa Żbikowska, 1983, and Polyzygia neodevonica aragonensis Gozalo \& Sanchez de Posada, 1986, are two example of subspecies (ecotype?) distinguishable only by the presence of spines.

Assemblages like this one observed at Pisacaviña are frequent in the Devonian. For example in the type region for the definition of the Frasnian stage (Dinant Synclinorium, Belgium), a similar assemblage is present at the top of the Neuville Formation where it follows an ostracod association rich in large and thick shelled Podocopids (= Ass. II) contemporaneous of the edification of the last Frasnian reefs, and where it precedes an ostracod fauna belonging to the Myodocopid MegaAssemblage. This one is indicative of the strong hypoxic water conditions related to the Late Frasnian Event (see plate 1 in Casier 2004). Similar assemblages are also recognised for example in Morocco (Casier et al. 2008), in Algeria (Casier 1983, 1985), and in South Africa (Becker et al. 1994). Consequently, we estimate that the 'Neritic Malvinokaffric ecotype' introduced by Lethiers et al. (2001), is not useful. Moreover, as we have seen, the term 'ecotype' must also be banished. That does not question the existence of a typical 'Malvinokaffric ostracod fauna' (Lethiers et al. 2001) because the fauna described from South America and South Africa should be endemic.

The presence of crinoid ossicle in the massive silicified limestone lens and in the ferrugineous thin layer rich in ostracods is intriguing because their are indicative of better conditions of oxygenation and probably of a more agitated shallow environment. In reality, beds rich in skeletal elements of crinoids are generally poor in ostracods. Moreover, ostracods grow by moulting and the studied

Figure 31. Ostracods. • A - Keslingiella sp. A, aff. K. pillai Pinto \& Purper, 1981. Internal mould of a carapace in right lateral view. FCGI $3524, \times 45$. - B - Keslingiella sp. A, aff. K. pillai Pinto \& Purper, 1981. Internal mould of a carapace in right lateral view. FCGI $3525, \times 45$. $\bullet$ C - Keslingiella sp. A, aff. K. pillai Pinto \& Purper, 1981. Internal mould of a carapace in right lateral view. FCGI, $\times 40$. $\bullet$ D - Keslingiella sp. A, aff. K. pillai Pinto \& Purper, 1981. Internal mould of a carapace in right lateral view. FCGI $3527, \times 45$. $\bullet$ E - Favulella? sp. B. Broken left valve. FCGI $3528, \times 45$. $\bullet$ F - Favulella? sp. A, aff. F. favulosa Jones, 1889, sensu Swartz \& Swain (1941). Right valve. FCGI 3529, × 70. • G - Bufina? sp. A. Internal mould of a left valve. FCGI $3530, \times 40 . \bullet \mathrm{H}-$ Bufina? sp. B. Internal mould of a right valve. FCGI 3531, × 50. $\bullet$ I - Zudanezina? sp. A. Internal mould of a right valve. FCGI 3532 , $\times 35 . \bullet J-$ Bairdiocypris? sp. indet. Broken right valve. FCGI $3533, \times 30 . \bullet \mathrm{K}-$ Bairdia $?$ sp. indet. Left valve. FCGI $3534, \times 30 . \bullet \mathrm{L}-$ Zudanezina? sp. A. External mould of a left valve. FCGI $3535, \times 30$. 

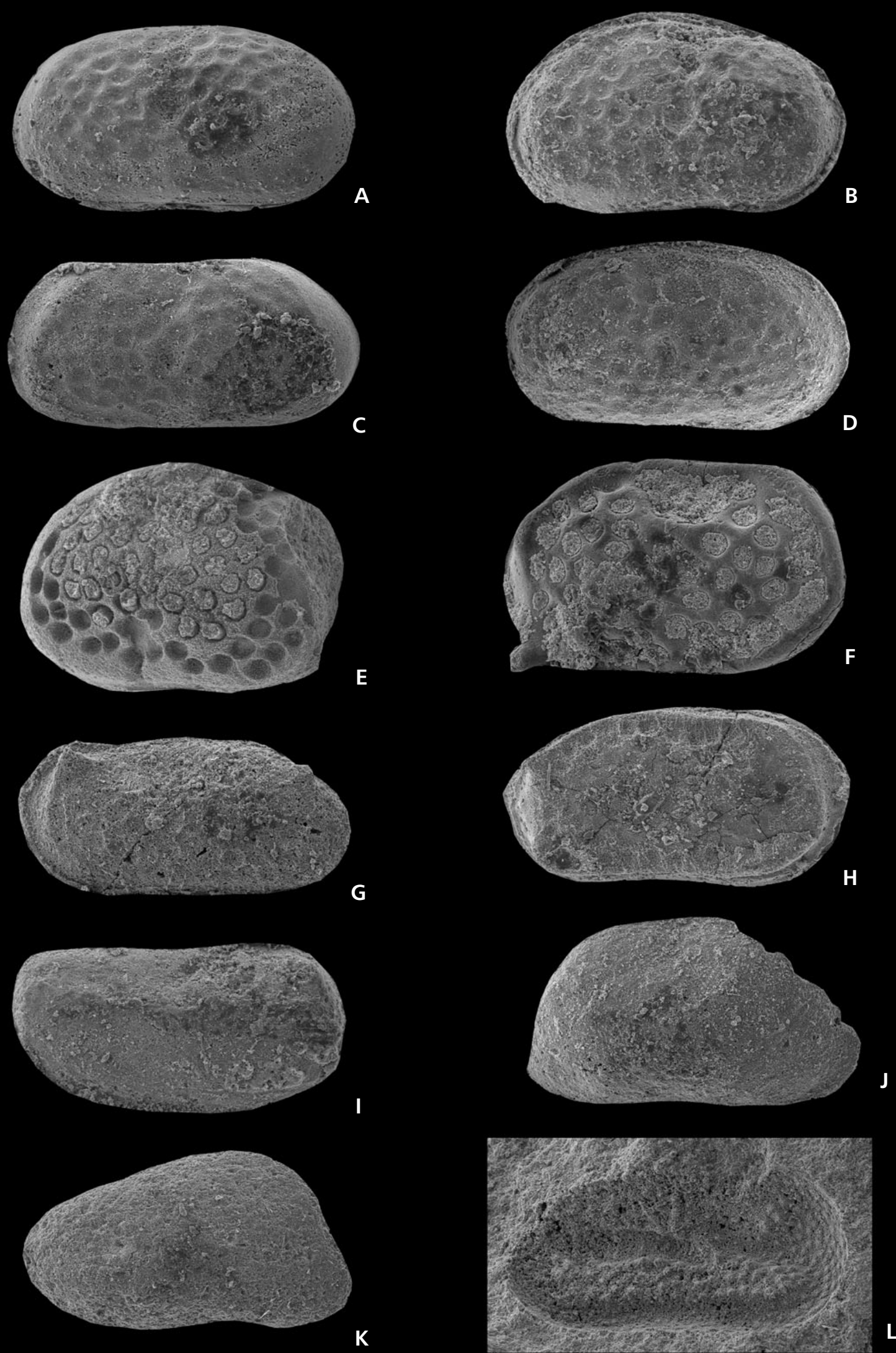
fauna is composed almost exclusively of adults. These two observations permit to suggest that the ostracod fauna is not in situ and has undergone a short transport probably linked to bottom currents. It is probably also the case for the skeletal elements of crinoids but their origin is different.

\section{Phyllocarida (Patrick R. Racheboeuf)}

Phyllocarid crustaceans are always rather uncommon fossils in the Palaeozoic of Bolivia, occurrences being up to now restricted to the Metacryphaeus caffer and Dipleura dekayi zones sensu Wolfart (1968). These levels belong to the upper part of the Belén Formation and to the Cruz Loma Quartzite, respectively (Hannibal et al. 1994, Racheboeuf 1998). During the ' 2005 ' field work three new localities provided us with phyllocarids fossils, among which the locality Pisacaviña which provided us with two specimens from two distinct levels: a mandible and a fragment of carapace but, unfortunately, it is not possible to ascertain the belonging of these two fossils to the same genus, and even more to a single species (Racheboeuf in prep.).

The mandible (FCGI 3512) is almost complete and nicely perserved, and it is undoubtedly the left one (Rolfe 1962, Dzik 1980). It is $17 \mathrm{~mm}$ long and $20 \mathrm{~mm}$ wide. The length of the pars incisiva is about $40 \%$ the total length of the gnathal lobe, and that of the pars molaris is about $60 \%$. The size, morphology, and relative development of incisiva and molaris parts suggest this mandible may belong to some representative of the genus Dithyrocaris.

The fragment of carapace (FCGI 3513) most probably belongs to the posteroventral ventral part of the right valve. The ventral location of the fragment is deduced from the curvature of the margin, as well as by the presence of the well differentiated border; the belonging of the fragment to the right valve results from the backwards orientation of the ornament on the border. The border is flat, and $0.5 \mathrm{~mm}$ to about $1 \mathrm{~mm}$ high in its straight and curved parts, respectively. The border is separated from the body of the valve by a narrow and shallow furrow, and it bears thin, dense, oblique, non anastomosing ridges oriented backwards from dorsal to ventral margin. The doublure of the border is about $1 \mathrm{~mm}$ high and it is divided in two parts: a markedly concave, ventral one which is about half the height of the doublure, and a flat to weakly convex dorsal one; both parts are separated by a narrow ridge. The body of the valve is oranmented with very thin, low and narrow, irregular, sinuous ridges of variable length which parallel the ventral margin; these ridges never bifurcate on the preserved part of the exoskeleton.
With respect to the morphology, profile and ornament of the ventral border, the carapace fragment most probably belongs to some representative of the Family Rhinocarididae, like Dithyrocaris oculea Racheboeuf, 1998 from the Cruz Loma Quartzite (D. dekayi Zone, Givetian). The nature of the very thin ornament of the valve is very distinct from that of D. oculea; this point strongly suggests that the fragment of carapace from Pisacaviña belongs to a new taxon for South America.

The Lochkovian nodules of the Kirusilla Formation at Rumicorral (Interandean Zone) provided us with three variably preserved, but still articulated, carapaces of a small phyllocarid which most probably represent a new genus of the Family Ceratiocarididae. It would be the first proven ceratiocaridid representative (?) from South America (Racheboeuf, unpublished)

\section{Vertebrates (Philippe Janvier)}

The vertebrate assemblage from Pisacaviña is much the same as that described from other outcrops of the Belén Formation in the Bolivian Altiplano, notably Chacoma (Patacamaya), but also in presumably coeval levels of the Icla Formation of the Subandean Zone (Janvier \& SuárezRiglos 1986, Janvier \& Maisey 2010). All the specimens recorded in situ from Pisacaviña are mostly unidentifiable chondrichthyans cartilage fragments, some unambiguous skull elements of the presumed stem chondrichthyan Pucapampella, and fragments of the so-called 'pterygial plates' of the still enigmatic gnathostome Zamponiopteron.

Class Chondrichthyes Huxley, 1871

\section{Genus Pucapampella Janvier \& Suárez-Riglos, 1986}

Type species. - Pucapampella rodrigae Janvier \& SuárezRiglos, 1986.

Type locality. - Unknown, probable Sica Sica area, probably Sica Sica Formation, Late Eifelian.

\section{Pucapampella cf. $P$. rodrigae Janvier \& Suárez-Riglos, 1986} Figure 32A, C

The genus Pucapampella is an unusual chondrichthyan, initially described on the basis of an isolated parachordal plate of the braincase, from the Belén Formation of Bolivia (Janvier \& Suárez-Riglos 1986). Subsequent discoveries from Bolivia and from the Lower Devonian of South 

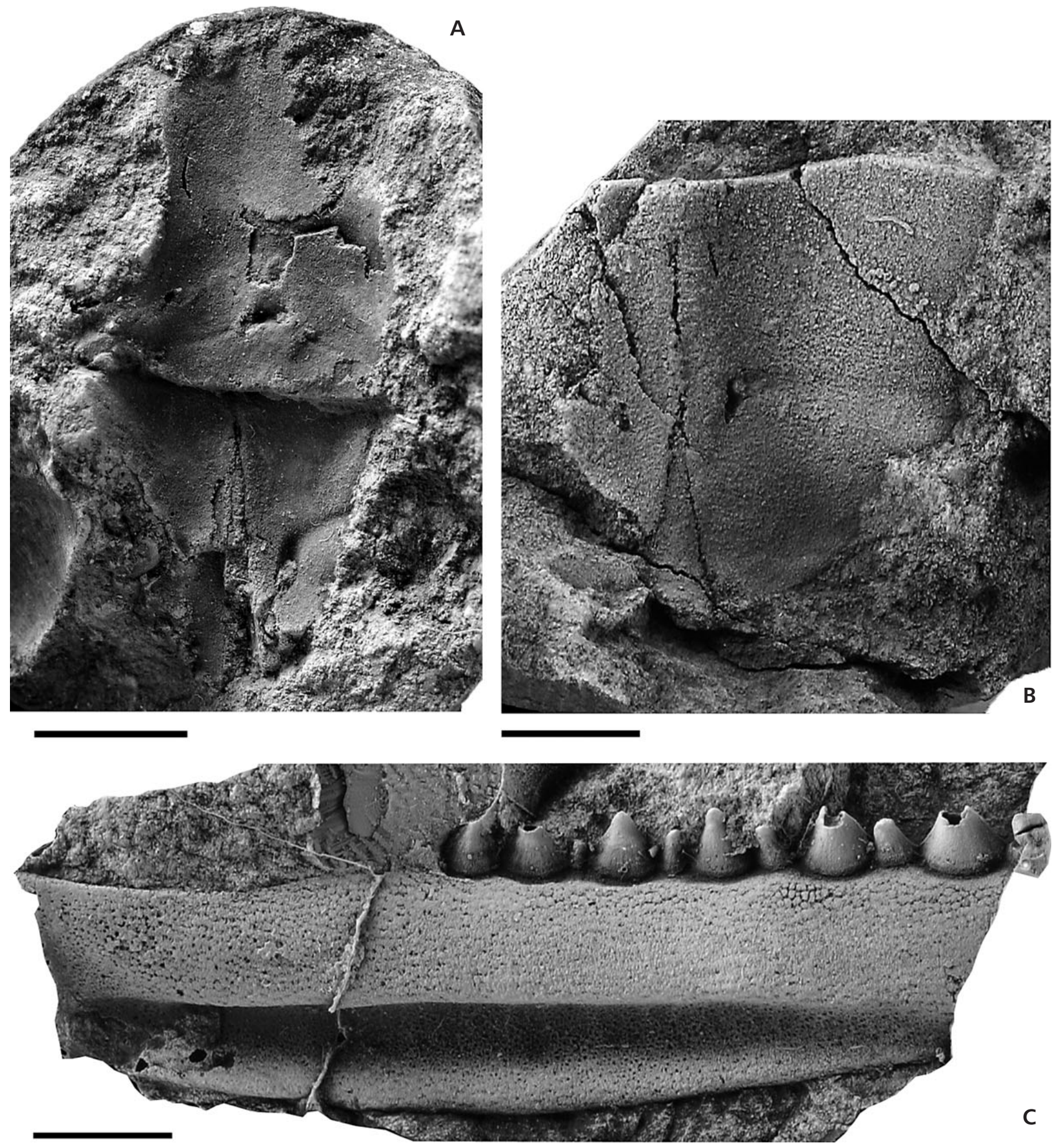

Figure 32. Vertebrates. Pucapampella cf. P. rodrigae Janvier \& Suárez-Riglos, 1986, Belén Formation, Middle Devonian, Eifelian, Pisacaviña, Department of La Paz, Bolivia. • A - articulated braincase in ventral view (MHNAO1325). B - incomplete isolated parachordal plate in ventral view (FCGV201). $\bullet \mathrm{C}$ - isolated Meckelian cartilage and associated tooth series, in medial view (FCGV 203). Scale bar $=5 \mathrm{~mm}$.

Africa have allowed a relatively extensive reconstruction of the braincase and mandibular arch of this genus (Anderson et al. 1999, Maisey 2001, Maisey \& Anderson 2001, Janvier 2003, Janvier \& Maisey 2010), which displays a peculiar assemblage of stem elasmobranch and osteichthyan characters, and is currently regarded as a possible stem chondrichthyan (Maisey 2001). A nodule from Pisacaviña contains the first articulated braincase of Pucapampella ever found in Bolivia (Fig. 32A). It is a comparatively small specimen, which shows the ventral surface of the ethmosphenoid division and parachordal plate almost in natural position. The ethmosphenoid division shows a 
relatively large hypophysial fenestra, as in the South African specimen described by Maisey \& Anderson (2001), but contrary to the isolated ethmosphenoid division from Bolivia described by Maisey (2001), suggesting an important variation as to this character in this genus. Unfortunately, $\mathrm{X}$-ray computed microtomography of this articulated specimen from Pisacaviña did not show evidence of extensive calcification of the braincase inside the nodule. In addition to this braincase, another nodule contains an imperfect parachordal plate, possibly associated with a fragment of the ethmosphenoid division (Fig. 32B). Another nodule contains a well preserved portion of the Meckelian cartilage, characteristically bearing a series of conical teeth that are directly attached to the prismatic calcified cartilage layer (Fig. 32C). The medial surface of this Meckelian cartilage shows a broad longitudinal groove, which is characteristic of Pucapampella and probably accommodated the ceratohyal (Janvier \& Maisey 2010).

Pucapampella is only known from the Belén and Icla formations of Bolivia, and the Gydo Formation of South Africa (Maisey \& Anderson 2001, Janvier \& Maisey 2010).

Subphylum Gnathostomata Gegenbaur, 1874

Order and family uncertain

Genus Zamponiopteron Janvier \& Suárez-Riglos, 1986

Type species. - Zamponiopteron triangularis Janvier \& Suárez-Riglos, 1986.

Type locality. - Campo Redondo, Huamampampa Formation, Late Eifelian-Early Givetian.

\section{Zamponiopteron sp.}

Zamponiopteron is a still enigmatic taxon, currently regarded as a gnathostome (jawed vertebrate) of uncertain relationships (Janvier \& Suárez-Riglos 1986; Lelièvre et al. 1993; Janvier 1977, 1991, 2003). It is only known from the Belén and Icla formations of Bolivia, and represented by peculiar, triangular to falciform elements enclosing parallel tubes, which recall Andean flutes (zampoña). These elements are assumed to be paired fin radials embedded in a massive structure made of calcified cartilage, and were referred to as 'pterygial plate' or 'fin plate' (Janvier \& Suárez-Riglos 1986; Janvier 1991, 2003; see discussion in Janvier \& Maisey 2010). Although three species of Zamponiopteron have been defined by Janvier \& Suárez-Riglos (1986), these elements display a remarkable diversity of shape. Two nodule fragments from Pisacaviña contain portions of large $\mathrm{Za}$ mponiopteron pterygial plates, unfortunately indeterminable at the species level.
Zamponiopteron is known exclusively from the Devonian of Bolivia. However, closely set paired fin radials from the Emsian Gydo and Tra Tra formations of South Africa have been compared to Zamponiopteron (Anderson et al. 1999, Janvier \& Maisey 2010), but these lack the massive calcification that surround the radials and characterizes the genus.

\section{Conclusions}

Besides new palaeontological data related to the Devonian of the Eastern Cordillerra of the Bolivian Altiplano (palynomorphs, plant, corals, brachiopods, trilobites, ostracods, and vertebrates), the main purpose of the present paper is to contribute to the knowledge of the Silurian and earliest Devonian deposits of the region. It was a real challenge since both the lithologic succession and the local geological history make the situation really complex, and a lot of work has still to be done to add to the faunal inventory, the identification of the successive faunas, and, as a consequence, biostratigraphy and correlations.

Based both on the established stratigraphic range and paleogeographic distribution of organisms (e.g. palynomorphs, the genus Petridyctium, and trilobites), and the morphological characters of others (chonetoideans, among which Sanjuanetes glemareci sp. nov., and Kentronetes giae sp. nov.), it appears likely that a large part of the supposed Silurian fossiliferous levels are older (i.e. Devonian) than previously stated.

It is evident that, due to the endemic character of most faunal elements (invertebrates), correlations and comparisons with the International Stratigraphic Time Scale is not easy, except for palynomorphs which are unfortunately often poorly preserved in field samples. Moreover, in the global context of the Cordilleran Bolivian Basin, it appears that the lithologic succession includes several stratigraphical gaps during the Silurian where they can only be identified through precise faunal identification.

\section{Acknowledgements}

This work is a contribution to the research projects CGL 2005-03715/BTE (financed by the Spanish Ministry of Education and Science and FEDER), the 'Fondation de France', and the IGCP 499. P.R. Racheboeuf, and co-authors, are greatly indebted to P.E. Isaacson (University of Idaho, College of Science, Department of Geological Sciences, Moscow, USA), E. Díaz-Martínez (Instituto de Geología Económica (CSIC-UCM), Facultad de Ciencias Geológicas, Madrid, Spain) for their exhaustive reading, comments, and corrections, of the manuscript which they greatly helped to improve. An anonymous reviewer, probably a palynologist, and the Editorial Board of the journal are also acknowledged for their useful global comments. 


\section{References}

Anderson, M.E., Almond, J.E., Evans, F.J. \& Long, J.A. 1999. Devonian (Emsian-Eifelian) fish from the Lower Bokkeveld Group (Ceres Subgroup), South Africa. Journal of African Earth Sciences 29, 179-194.

DOI 10.1016/S0899-5362(99)00088-3

Babin, C., Deunff, J., Mélou, M., Paris, F., Pelhate, A., PlusQuellec, Y. \& Racheboeuf, P.R. 1979. La coupe de Porz ar Vouden (Př́idolí de la Presqu'île de Crozon) Massif armoricain, France. Lithologie et biostratigraphie. Palaeontographica A 164, 52-84.

BALDIS, B. \& Rossi dE GARCiA, E. 1975. Ostracodes dévoniens argentins associés à la faune Malvinokafrique. Proceedings of the $V^{\text {th }}$ African Colloquium on Micropaleontology, AddisAbeba, 10-12 April 1972. Enadimsa Ediciones 7(3), 57-92.

BANDEL, K. \& BeCKer, G. 1975. Ostracoden aus paläozoischen pelagischen Kalken der Karnischen Alpen (Silurium bis Unterkarbon). Senckenbergiana lethaea 56(1), 1-83.

BeCKER, G., Bless, M. \& Theron, J. 1994. Malvinokaffric ostracods from South Africa (Southern Cape; Bokkeveld Group, Devonian). Courier Forschunginstitut Senckenberg 169, 239-259.

Blieck, A., Gagnier, P.-Y., Bigey, F., Edgecombe, G.D., Janvier, P., Loboziak, S., Racheboeuf, P.R., Sempere, T. \& Steemans, P. 1996. New Devonian fossil localities in Bolivia. Journal of South American Earth Sciences 9(5/6), 295-308. DOI 10.1016/S0895-9811(96)00015-6

BouČEK, B. 1936. Die Ostrakoden des Boehmischen Ludlows (Stufe E Beta). Neues Jahrbuch für Mineralogie, Geologie und Paläontologie, Abteilung B 76(1), 31-98.

Boucot, A.J. \& AmSDEN, T.W. 1964. Chonostrophiella, a new genus of chonostrophiid brachiopod. Journal of Paleontology $38,881-884$.

Boucot, A.J. \& HARPER, C.W. 1968. Silurian to lower Middle Devonian Chonetacea. Journal of Paleontology 42, 143-176.

Boucot, A.J., Johnson, J.G. \& Talent, J.A. 1969. Early Devonian brachiopod zoogeography. The Geological Society of America, Special Paper 119, 1-113.

Boumendjel, K. 1987. Les Chitinozoaires du Silurien Supérieur et du Dévonien du Sahara algérien (cadre géologique, systématique, biostratigraphie). $181 \mathrm{pp}$. Doctoral thesis of Rennes University (unpublished).

BoumendjeL, K. 2002. Nouvelles espèces de chitinozoaires du Silurien supérieur et du Dévonien inférieur du Bassin de Timimoun (Sahara central, Algérie). Review of Palaeobotany and Palynology 118, 29-46. DOI 10.1016/S0034-6667(01)00106-3

Boumendjel, K., Morzadec, P., Paris, F. \& Plusquellec, Y. 1997. Le Dévonien de l'Ougarta (Sahara occidental, Algérie). Annales de la Société géologique du Nord, 5 (2ème sér.), 73-87.

Boureau, E. 1967. Traité de Paléobotanique. Tome II. 834 pp. Masson et Cie, Paris.

Brachert, T.C., Buggisch, W., Flügel, E., Hüssner, H.M., JoAchimski, M.M., Tourneur, F. \& Walliser, O.H. 1992. Controls of mud mound formation: the Early Devonian KessKess carbonates of the Hamar Laghdad, Antiatlas, Morocco. Geologische Rundschau 81(1), 15-44. DOI 10.1007/BF01764537

Branisa, L. 1965. Los fosiles guias de Bolivia. Servicio Geológico de Bolivia, Boletin 6, 1-282.
Branisa, L. 1969. El sistema Silúrico en Bolivia: estratigrafía, faunas y límites. I. El límite entre el Silúrico y el Devónico. Boletín de la Sociedad Geológica Boliviana 12, 22-70.

Brockmann, C., Castaños, A., Suárez, R. \& Tomasi, P. 1972. Estudio Geológico de la Cordillera Oriental de Los Andes en la Zona Central de Bolivia. Boletin de la Sociedad Geológica Boliviana 18, 3-36.

CAsier, J.-G. 1983. Les ostracodes du Frasnien et de la base du Famennien de la coupe du km 30 (Saoura, Sahara algérien). Bulletin de la Société belge de Géologie 91(1982), 195-207.

CASIER, J.-G. 1985. Les ostracodes de la partie supérieure de la Formation de Teferguenite (Givétien) et de la Formation de Marhouma (Givétien-Famennien) de la coupe du km 30 (Saoura, Sahara algérien). Geobios 18(6), 833-846 [see also erratum in Geobios 19(2), 266]. DOI 10.1016/S0016-6995(85)80038-3

CASIER, J.-G. 1987. Etude biostratigraphique et paléoécologique des ostracodes du récif de marbre rouge du Hautmont à Vodelée (partie supérieure du Frasnien, Bassin de Dinant, Belgique). Revue de Paléobiologie 6(2), 193-204.

CAsIER, J.-G. 2004. The mode of life of Devonian entomozoacean ostracods and the Myodocopid Mega-Assemblage proxy for hypoxic events. Bulletin de l'Institut Royal des Sciences naturelles de Belgique, Sciences de la Terre 74 (Supplement), 73-80.

Casier, J.-G., Lebon, A., Mamet, B. \& Préat, A. 2005. Ostracods and lithofacies close to the Devonian-Carboniferous boundary in the Chanxhe and Rivage sections, northeastern part of the Dinant Basin, Belgium. Bulletin de l'Institut Royal des Sciences naturelles de Belgique, Sciences de la Terre 75, 95-126.

Casier, J.-G., El Hassani, A. \& PrÉat, A. 2010. Ostracodes du Dévonien moyen et supérieur du Tafilalt (Maroc). Revue de Micropaléontologie 53(1), 29-51. DOI 10.1016/j.revmic.2008.06.003

Clarke, J.M. 1913. Fósseis Devonianos do Paraná. Monographias do Serviço Geológico Mineralógico do Brasil 1, 1-353.

CoRyell, H. \& MalKin, D. 1936. Some Hamilton ostracodes from Arkona, Ontario. American Museum Novitates 891, 1-20.

Cramer, F.H. 1970. Distribution of selected Silurian acritarchs. Revista Española de Micropaleontología, número extraordinario, 1-203.

Cramer, F.H. \& Rodriguez, R. 1977. Robledo and Arroyacas Formation (Arroyo de Las Arroyacas, Province of Palencia (Spain), palynologically dated as Late Silurian. Breviora Geológica Asturica 21(1), 2-4.

Cramer, F.H., Diez, D.C.R. \& Cuera, A.J. 1974. Late Silurian chitinozoans and acritarchs from Cochabamba, Bolivia. Neues Jahrbuch für Geologie und Paläontologie, Monatshefte 1974(1), 1-12.

DeunfF, J. 1980. Le paléoplancton des Grès de Landévennec (Gedinnien de la Rade de Brest, Finistère). Etude biostratigraphique. Geobios 13(4), 483-539.

Dubatolov, V.N. 1959. Tabuljaty, geliolitidy i khetetidy silura i devona Kuznetskogo basseina. Trudy VNNIGI (VNIGRI) 139, $1-472$.

Dubatolov, V.N. 1969. Tabuljaty i biostratigrafiya nijnego Devona Severo-Vostoka SSSR. Akademiya Nauk SSSR, Sibirskoe otdelenie, Trudy Instituta geologii i geofisiki 70, 1-179.

DzIK, J. 1980. Isolated mandibles of Early Palaeozoic phyllocarid Crusttacea. Neues Jahrbuch für Geologie und Paläontologie, Monatshefte 1980(2), 87-106. 
Edgecombe, G.D. \& Fortey, R.A. 2000. Silurian trilobites from the El Carmen Formation, Bolivia. Senckenbergiana lethaea 79(2), 329-355. DOI 10.1007/BF03043645

Edgecombe, G.D. \& RAmsköLd, L. 1994. Earliest Devonian phacopide trilobites from central Bolivia. Paläontologische Zeitschrift 68, 397-410.

Eisenack, A. 1934. Neue Mikrofossilien des baltischen Silurs, III, und neue Mikrofossilien des böhmischen Silurs, I. Paläontologische Zeitschrift 16, 52-76.

Eisenack, A. 1937. Neue Mikrofossilien des baltischen Silurs, IV. Paläontologische Zeitschrift 19, 217-243.

Eisenack, A. 1964. Mikrofossilien aus dem Silur Gotlands. Chitinozoen. Neues Jahrbuch für Geologie und Paläontologie, Abhandlungen 120, 308-342.

Fernández-Martínez, E., Plusquellec, Y. \& Castaño de Luis, R. 2007. Corales tabulados del Devónico inferior de Argentina y Bolivia: estado de la cuestión, 143-148. In DíAz-MARTínEZ, E. \& RÁBANo, I. (eds) $4^{\text {th }}$ European Meeting on the Palaeontology and Stratigraphy of Latin America. Cuadernos del Museo Geominero 8.

Fernández-Martínez, E., Plusquellec, Y., Tourneur, F. \& HerRERA, Z. 1999. Nueva especie de tabulado del Devónico inferior de Argentina. Revista Española de Paleontología 14(1), 37-57.

FernándeZ-MartíneZ, E. \& Tourneur, F. 1995. Tabulate coral faunas from the Lower Devonian of Colle and "Plataforma de Arnao" (Cantabrian Mountains, NW Spain). Paleogeographical affinities. VII International Symposium on Fossil Cnidaria and Porifera, Madrid (Abstracts), 23-24.

Gozalo, R. \& Sanchez De Posada, L. 1986. Polyzygia neodevonica aragonensis (Ostracoda) nueva subespecie del Devónico de la Cordillera Ibérica. Revista Española de Micropaleontología 18, 415-421.

GRAHN, Y. 2002. Upper Silurian and Devonian Chitinozoa from central and southern Bolivia, central Andes. Journal of South American Earth Sciences 15, 315-326. DOI 10.1016/S0895-9811(02)00045-7

Hannibal, J.T., Feldmann, R.M. \& Rolfe, W.D.I. 1994. Phyllocarid crustaceans from the Devonian of Bolivia. Revista Técnica de YPFB 13-14, 59-69.

HerrerA, Z.A. 1993. Nuevas precisiones sobre la edad de la Formación Talacasto (Precordillera Argentina) en base a su fauna de Braquiópodos. XII Congreso Geológico Argentino y II Congreso de Exploración de Hidrocarburos, Actas II, 289-295.

Herrera, Z.A. 1995. The Lower Devonian chonetoidean brachiopods from the Argentine Precordillera. Documents des Laboratoires de Géologie de Lyon 136, 101-147.

JAGLIN, J.-C. 1986. Nouvelles espèces de Chitinozoaires du Př́ídolí de Libye. Revue de Micropaléontologie 29(1), 44-54.

JANVIER, P. 1977. Description de restes d'élasmobranches (Pisces) du Dévonien moyen de Bolivie. Palaeovertebrata 7, 126-132.

JANVIER, P. 1991. Silurian and Devonian vertebrates, 381-388. In SuÁrez-Soruco, R. (ed.) Fosíles y Facies de Bolivia, 1, Vertebrados. Revista Técnica de Yacimientos Petrolíferos Fiscales Bolivianos 12. Santa Cruz.

JANVIER, P. 2003. The Devonian vertebrates from Bolivia: new data, more enigmas. Revista Tecnica de Yacimientos Petroliferos Fiscales Bolivianos 21, 25-35.

JAnVier, P. \& Maisey, J.G. 2010. The Devonian vertebrates of South America and their biogeographical relationships. In $\mathrm{YU}_{\mathrm{U}}$
X.-B., Maisey, J.G. \& Elliott, D. (eds) Morphology, Phylogeny and Biogeography of Fossil Fishes. Verlag Dr. Friedrich Pfeil, Munich.

JANVIER, P. \& SuÁrez-Riglos, M. 1986. The Silurian and Devonian vertebrates of Bolivia. Bulletin de l'Institut Français d'Etudes Andines, Lima 15, 73-114.

Jardiné, S., Combaz, A., Magloire, L., Peniguel, G. \& Vachey, G. 1972. Acritarches du Silurien terminal et du Dévonien du Sahara Algérien. Compte rendu, $7^{\mathrm{m} m}$ Congrès International de Stratigraphie et de Géologie du Carbonifère, Krefeld 1, 295-311.

Jardiné, S., Combaz, A., Magloire, L., Peniguel, G. \& Vachey, G. 1974. Distribution stratigraphique des acritarches dans le Paléozoïque du Sahara algérien. Review of Palaeobotany and Palynology 18, 99-119.

Jones, T. 1889. On some Palaeozoic Ostracoda from Pennsylvania, U.S. American Geologist 4(6), 337-342.

JoNES, T. 1890. On some Devonian and Silurian Ostracoda from North America, France, and the Bosphorus. Quarterly Journal of the Geological Society of London 46(4), 534-556.

DOI 10.1144/?GSL.JGS.1890.046.01-04.34

KAYSER, E. 1897. Beiträge zur Kenntniss einiger paläozoischer Faunen Süd-Amerikas. Zeitschrift der Deutschen geologischer Gesellschaft 1897, 274-317.

Kegel, W. 1932. Zur Kenntnis Palaeozoischer Ostrakoden: 2. Bairdiidae aus dem Mitteldevon des Rheinischen Schiefergebirges. Jahrbuch der Preussichen Geologischen Landesanstalt zu Berlin 52, 245-250.

KNoD, R. 1908. Devonischen Faunen Boliviens, 493-600. In Steinmann, G. (ed.) Beiträge zur Geologie und Paläontologie von Südamerika. Neues Jarhbuch für Geologie und Paläontologie 25.

Kozlowski, R. 1923. Faune Dévonienne de Bolivie. Annales de Paléontologie 12, 1-112.

Lafuste, J. \& Plusquellec, Y. 1976. Kerforneidictyum n. gen. (Tabulata, Dévonien). Morphologie et microstructure. Bulletin de la Société géologique de France 18, 1699-1711.

Lafuste, J., Semenoff-Tian-Chansky, P. \& Tourneur, F. 1992. Succession microlamelles-lamelles dans le sclérenchyme pariétal de Syringopora Goldfuss, 1826 (Tabulata, Carbonifère). Bulletin du Muséum national d'Histoire naturelle, Paris $14 C(3 / 4), 249-265$.

Le Hérissé, A. 2002. Paleoecology, biostratigraphy and biogeography of Late Silurian to early Devonian acritarchs and Prasinophycean phycomata in well A161, Western Libya, North Africa. Review of Paleobotany and Palynology 118, 359-395. DOI 10.1016/S0034-6667(01)00123-3

Le Hérissé, A., Servais, T. \& Wicander, R. 2000. Devonian acritarchs and related forms. Courier Forschungsinstitut Senckenberg 220, 195-205.

Lejal-Nicol, A. 1972. Contribution à l'étude de la flore paléozoïque à Lycophytes de Libye et des bassins du Djado et de Fort-Polignac (Illizi). 434 pp. Thèse d'État, Université Paris VI, (unpublished).

Lelièvre, H., Janvier, P. \& Blieck, A. 1993. Silurian-Devonian vertebrate biostratigraphy of Western Gondwana and related terranes (South America, Africa, Armorica-Bohemia, Middle-East), 139-173. In Long, J.A. (ed.) Palaeozoic Vertebrate Biostratigraphy and Biogeography. Belhaven, London. 
LE Maître, D. 1952. La faune du Dévonien inférieur et moyen de la Saoura et des abords de l'Erg El Djemel. Matériaux pour la carte géologique de l'Algérie, Paléontologie 12, 1-170.

Lethiers, F. \& Crasquin-Soleau, S. 1988. Comment extraire les microfossiles à tests calcitiques des roches calcaires dures. $R e$ vue de Micropaléontologie 31(1), 56-61.

Lethiers, F., Racheboeuf, P., Baudin, F. \& Vaccari, E. 2001. A typical Malvinokaffric Givetian ostracod fauna from Bolivia. Revue de Micropaléontologie 44(4), 301-317.

DOI 10.1016/S0035-1598(01)90123-0

Limachi, R., Goitia, V.H., Sarmiento, D., Arispe, O., Montecinos, R., Díaz-Martínez, E., Dalenz Farjat, A., Liachenko, N., Perez leyton, M. \& Aguilera, E. 1996. Estratigrafía, geoquímica, correlaciones, ambientes sedimentarios y bioestratigrafía del Silúrico-Devónico de Bolivia. Memorias del XII Congreso Geológico de Bolivia, 183-197.

LoEBlich, A.R. \& WicANDER, R. 1976. Organic-walled microplankton from the Lower Devonian (Late Gedinnian) Haraganand Bois d'Arc Formations, Oklahoma, USA, part 1. Palaeontographica, Abteilung B 159, 1-39.

McCoy, F. 1844. A synopsis of the characters of the Carboniferous Limestone fossils of Irlande. 207 pp. M.H. Gill, Dublin University Press, Dublin.

McGRegor, D.C. 1984. Late Silurian and Devonian spores from Bolivia. Academia Nacional de Ciencias, Cordoba, Miscellaneous 69, 1-57.

MAISEY, J.G. 2001. A primitive chondrichthyan braincase from the Middle Devonian of Bolivia, 263-288. In AhLBERG, P.E. (ed.) Major Events in Early Vertebrate Evolution. Taylor \& Francis, London.

Maisey, J.G. \& ANDERSON, M.E. 2001. A primitive chondrichthyan braincase from the Early Devonian of South Africa. Journal of Vertebrate Paleontology 21, 702-713. DOI 10.1671/0272-4634(2001)021[0702:APCBFT]2.0.CO;2

MeLo, J.H.G. 2005. Palynostratigraphy of some Palaeozoic rock units of Bolivia: Additional results. Actas del VI Congreso de Exploracion y Desarrollo de Hidrocarburos (VI CONEXPLO). Mar del Plata, Argentina, 20 pp. (CD-Rom, Trabajos Técnicos).

Oвuт, A.M. 1973. On the geographical distribution, comparative morphology, ecology, phylogeny and systematical position of the Chitinozoa, 72-84. In Betekhtina, O.A. \& Zhuravleva, I.T. (eds) The environment and the life through geological times. Nauka, Novosibirsk. [in Russian]

Oliver, W.A. 1979. Sponges, they are not. Paleobiology 5(2), 188-190.

PAris, F. 1981. Les Chitinozoaires dans le Paléozoïque du Sudouest de l'Europe (Cadre géologique - Etude systématique Biostratigraphie). Mémoires de la Société géologique et minéralogique de Bretagne 26, 1-496.

PeK, I. \& VANĚK, J. 1991. On some Silurian and Devonian trilobites of Bolivia. Acta Universitatis Palackianae Olomucensis, Facultas rerum naturalium, Geographica-Geologica 103, 75-104.

Pinto, I. \& Purper, I. 1981. New lower Paleozoic ostracodes from Bolivia, 45-57. In Sanguinetti, Y. (ed.) Anais do II Congresso Latino-Americano de Paleontologia, Porto Alegre.

Plusquellec, Y. 1976. Les Polypiers-Tabulata, 183-215. In Lardeux, H. (ed.) Les Schistes et calcaires éodevoniens de
Saint-Céneré. Mémoires de la Société géologique et minéralogique de Bretagne 19.

Plusquellec, Y. 2007. Histoire naturelle des pleurodictyformes (Cnidaria, Tabulata, Dévonien) du Massif Armoricain et des régions Maghrebo-européennes principalement. Mémoires de la Société géologique et minéralogique de Bretagne 32, 1-138.

Plusquellec, Y., Lafuste, J. \& Webb, G. 1990. Organisation de type tétracoralliaire des rides septales de Palaeacis (Cnidaria, Carbonifère). Lethaia 23(4), 385-397.

DOI 10.1111/j.1502-3931.1990.tb01371.x

PÖthe DE BALDIS, E.D. 1975. Microplancton de la Formación Los Espejos, provincia de San Juan, Republica Argentina. Revista Española de Micropaleontología 7, 507-518.

PöTHE DE BALDIS, E.D. 1978. Paleomicroplancton addicional del Devonico Inferior de Uruguay. Revista Española de Micropaleontología 9, 235-250.

Powell, J.H. \& SCRUTTON, C.T. 1978. Variation in the Silurian tabulate coral Paleofavosites asper, and the status of Mesofavosites. Palaeontology 21(2), 307-319.

Prantl, F. \& PŘIBYL, A. 1949. A study of the superfamily Odontopleuracea nov. superf. (Trilobites). Rozpravy Ústředního ústavu geologického 12, 1-221.

PřIBYL, A. 1984a. New ostracodes from the Lower Devonian of Bolivia. Časopis pro mineralogii a geologii 29(1), 29-42.

PřIBYL, A. 1984b. Ostracodes from the Ordovician and Silurian of Bolivia. Časopis pro mineralogii a geologii 29(4), 353-374.

Racheboeuf, P.R. 1992. Los Chonetaceos (Braquiópodos) del Devónico boliviano: bioestratigrafía y datos taxonómicos complementarios. Revista Española de Paleontología 7, 31-52.

Racheboeuf, P.R. 1998. The Chonetoidean brachiopods. Documents des Laboratoires de Géologie de Lyon 148, 1-178.

Racheboeuf, P.R. 2000. Suborder Chonetidina, H362-H423. In KAESLER, L.R. (ed.) Treatise on Invertebrate Paleontology, revised edition. Part H, 2. Geological Society of America \& University of Kansas Press, Boulder \& Lawrence.

Racheboeuf, P.R. \& Herrera, Z. 1994. On some Malvinokaffric Silurian and Devonian chonetacean brachiopods, and reclassification of others. Neues Jahrbuch für Geologie und Paläontologie, Monatshefte 9, 541-560.

Racheboeuf, P.R. \& Isacson, P.E. 1994. Los Chonetaceos (Braquiópodos) Silúricos y Devónicos de Bolivia. Revista Técnica de YPFB 13-14, 99-119.

Racheboeuf, P.R., Le Hérissé, A., Paris, F., Babin, C., Guillocheau, F., Truyols-Massoni, M. \& Súarez-Soruco, R. 1993. Le Dévonien de Bolivie: biostratigraphie et chronostratigraphie. Comptes-Rendus de l'Académie des Sciences, Paris 317(2), 795-802.

RAMSKÖLD, L. \& ChATTERTON, B.D.E. 1991. Revision and subdivision of the polyphyletic "Leonaspis" (Trilobita). Transactions of the Royal Society of Edinburgh, Earth Sciences 82, 333-371.

RoLFE, W.D.I. 1962. Grosser morphology of the Scottish Silurian phyllocarid crustacean, Ceratiocaris papilio Salter in Murchison. Journal of Paleontology 36(5), 912-932.

Rosside Garcia, E. \& Proserpio, C. 1976. Ostracodos Devónicos de la zona de Jachal provincia de San Juan. Actas del primero Congreso Argentino de Paleontologia y Biostratigrafia, Tucuman, Argentina, 241-254.

Rubinstein, C.V., Melo, J.H.G. \& Steemans, P. 2005. Loch- 
kovian (Earliest Devonian) miospores from the Solimões Basin, northern Brazil. Review of Paleobotany and Palynology 133, 91-113. DOI 10.1016/j.revpalbo.2004.09.003

Rubinstein, C.V., Le Hérissé, A. \& Steemans, P. 2008. Lochkovian (Early Devonian) acritarchs and prasinophytes from the Solimoes Basin, northwestern Brazil. Neues Jahrbuch für Geologie, Abhandlungen 249, 167-184.

DOI 10.1127/0077-7749/2008/0249-0167

SANDFORD, A.C. 2005. Homalonotid trilobites from the Silurian and Lower Devonian of south-eastern Australia and New Zealand (Arthropoda: Trilobita: Homalonotidae). Memoirs of Museum Victoria 62(1), 1-66.

SARS, G. 1888. Nye bitrag til kundskaben om middlehavets invertebratfauna. 4. Ostracoda Mediterranea. Archiv for Mathematik og Naturvindenskab 12, 173-324.

Sohn, I. \& Stover, L. 1961. Family Bufinidae, Q375-Q376. In Moore, C. (ed.) Treatise on Invertebrate Paleontology. Part Q. Arthropoda 3. Geological Society of America \& University of Kansas Press, Boulder \& Lawrence.

Shaver, R. 1961. Family Bairdiocyprididae, Q364-Q367. In Moore, C. (ed.) Treatise on Invertebrate Paleontology. Part Q. Arthropoda 3. Geological Society of America \& University of Kansas Press, Boulder \& Lawrence.

Steemans, P. 1989. Palynostratigraphie de l'Eodévonien dans l'Ouest de l'Europe. Mémoires pour servir à l'explication des Cartes Géologiques et Minières de la Belgique 27, 1-453.

Steemans, P., Rubinstein, C. \& De Melo, J.H.G. 2008. SiluroDevonian miospore biostratigraphy of the Urubu River area, western Amazon Basin, northern Brazil. Geobios 41, 263-282. DOI 10.1016/j.geobios.2007.06.003

Suarez-Soruco, R. \& Lobo-Boneta, J. 1983. La fase Compresiva Eohercínica en el Sector Oriental de la Cuenca Cordillerana de Bolivia. Revista Técnica de Yacimientos Petroliferos Fiscales Bolivianos 9, 189-202.

Swartz, F. \& Swain, F. 1941. Ostracodes of the Middle Devonian Onondaga Beds of Central Pennsylvania. Bulletin of the Geological Society of America 52, 381-457.

Taugourdeau, P. \& De Jekhowsky, B. 1960. Répartition et description des chitinozoaires siluro-dévoniens de quelques sondages de la C.R.E.P.S., de la C.F.P.A. et de la S.N. Repal au Sahara. Revue de l'Institut Français du Pétrole 15(9), 1199-1260.

Termier, G. \& Termier, H. 1950. Paléontologie marocaine. II Invertébrés de l'ére primaire, 1 Foraminifères, Spongiaires et Coelentérés. 220 pp. Hermann \& Cie, Paris.

Tiella-Colque, L., GonZÁles, M., Espinoza, F., Sánchez, Y. \& BALDELlón, E. 1998. Apuntes de la Formación Belén de la región de Patacamaya y Sica Sica. Memorias del XIII Congreso Geológico de Bolivia, Potosí, Bolivia 1, 117-119.

Tomczyкowa, E. 1975. The trilobite subfamily Homalonotinae from the Upper Silurian and Lower Devonian of Poland. Acta Palaeontologica Polonica 20(1), 3-46.

Toro, M., Beltrán, J.M., Martínez, D. \& Guerrero, R. 2003. La fauna silúrica de la región de Ñuñumayani, departamento de La Paz. Revista Técnica de YPFB 21, 259-264.

Toro, M., Churata, E., Quispe, W., Burga, S., Martinez, D., Mendoza, D. \& Bustillos, D. 2008. Los bivalvos wenlockianos de la Formación Uncía en las nacientes de la Quebrada de Huacallani - Departamento de La Paz. Revista Boliviana de Geociencias 2, 15-28.
Toro, M. \& García-Duarte, R. 2002. Bioestratigrafía de las rocas siluro-devónicas aflorantes en el margen oriental de la Cuenca de La Paz. Memorias del XIV Congreso Geológico Boliviano, 402-405.

Toro, M., García-Duarte, R., Martínez, D., Mendoza, D., BeltrÁn, J.M. \& ZeBallos, A. 2004. Análisis bioestratigráfico de las unidades paleozoicas aflorantes al Sur de la Ciudad de La Paz. Memorias del XVI Congreso Geológico Boliviano, 84-89.

Toro, M., Garcia, R., Martínez, D., Mendoza, D.E., Claure, V., QuisPe, W., Burga, S. \& BAscopé, A. 2006. Los Trilobites Wenlockianos de la Formación Uncia en la Quebrada Huacallani al Sur de la Ciudad de La Paz. Memorias del XVII Congreso Geológico Boliviano, 30-35.

Tourneur, F. 1992. Présence du genre Parastriatopora Sokolov 1949 (Tabulata) dans le Dévonien inférieur de la Bolivie: implications paléogeographiques. Table Ronde Européenne, Lyon, 7-9 juillet 1992, 47.

Tourneur, F. \& FernándeZ-Martínez, E. 1991. Parastriatopora cantabrica, nueva especie de Tabulado del Devónico inferior (Emsiense) de la Cordillera Cantábrica (NO de España). Revista Española de Paleontología 6(1), 3-19.

Tourneur, F., Plusquellec, Y., Fernández-Martínez, E. \& Díaz-Martínez, E. 2000. Revision of Parastriatopora gigantea (Knod, 1908) (Anthozoa, Tabulata) from the Devonian of Bolivia. Geobios 33(6), 709-724.

Ulrich, E. 1890. New and little known American Paleozoic Ostracoda (1). Journal of the Cincinnati Society of Natural History 13(3), 104-137.

Ulrich, E. 1894. The lower Silurian Ostracoda of Minnesota. Final Report of the Geological and Natural History Survey of Minnesota 3(2), 629-693.

Van Der Meer, J.J.M. \& Wicander, R. 1992. A Silurian-Devonian acritarch flora from Saalian till in the Netherlands. Boreas 21, 153-157.

Vannier, J., Racheboeuf, P. \& Benedetto, J. 1995. SilurianEarly Devonian Ostracodes from South America (Argentina, Bolivia): Preliminary investigations. Journal of Paleontology 69(4), 752-772.

Volkheimer, W., Melendi, D.L. \& Salas, A. 1986. Devonian Chitinozoans from Northwestern Argentina. Neues Jahrbuch für Geologie und Paläontologie, Abhandlungen 173(2), 229-251.

WICANDER, R. 1986. Lower Devonian (Gedinnian) acritarchs from the Hagaran Formation, Oklahoma, U.S.A. Review of Palaeobotany and Palynology 47, 327-365. DOI 10.1016/0034-6667(86)90042-4

Wolfart, R. 1968. Die Trilobiten aus dem Devon Boliviens und ihre Bedeutung für Stratigraphie und Tiergeographie, 5-201. In Wolfart, R. \& Voges, A. Beiträge zur Kenntnis des Devons von Bolivien. Beihefte zum Geologischen Jahrbuch 74.

WronA, R. 1980. Upper Silurian - Lower Devonian Chitinozoa from the subsurface of southeastern Poland. Palaeontologia Polonica 41, 103-165.

Yen, S.-D. \& Zhou, X.-Y. 1975. The Early Middle Devonian Tabulatomorphic Corals from the Logdongshui Formation of Duyun, Kueichow Province. Professional Papers of Stratigraphy and Paleontology 1, 111-134.

ŻBikowsKA, B. 1983. Middle to upper Devonian ostracods from northwestern Poland and their stratigraphic significance. Palaeontologia Polonica 44, 3-108. 